\title{
QUANTIFICAÇÃO DE AMINOÁCIDOS SOLÚVEIS EM MUTANTES DE ENDOSPERMA DE MILHO
}

\author{
ALEJANDRO ALBERTO TORO
}

Dissertação apresentada à Escola Superior de Agricultura "Luiz de Queiroz", Universidade de São Paulo, para a obtenção do título de Mestre em Agronomia, Área de concentração: Genética e Melhoramento de Plantas.

PIRACICABA

Estado de São Paulo - Brasil

Novembro - 2001 


\section{QUANTIFICAÇÃO DE AMINOÁCIDOS SOLÚVEIS EM MUTANTES DE ENDOSPERMA DE MILHO}

\section{ALEJANDRO ALBERTO TORO}

Orientador: Prof. Dr. Ricardo Antunes de Azevedo

Dissertação apresentada à Escola Superior de Agricultura "Luiz de Queiroz", Universidade de São Paulo, para a obtenção do título de Mestre em Agronomia, Área de concentração: Genética e Melhoramento de Plantas.

PIRACICABA

Estado de São Paulo - Brasil

Novembro - 2001 
Dados Internacionais de Catalogação na Publicação (CIP) DIVISÃO DE BIBLIOTECA E DOCUMENTAÇÃO - ESALQ/USP

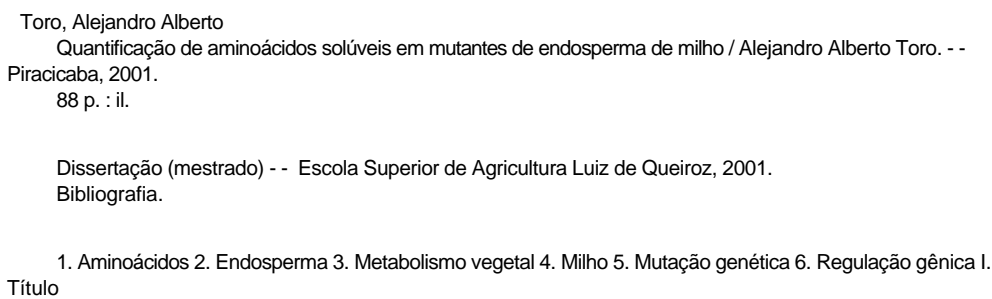

CDD 633.15

\section{"Permitida a cópia total ou parcial deste documento, desde que citada a fonte - $\mathrm{O}$ autor"}




\section{DEDICATÓRIA}

\section{A MI FAMÍLIA...}

...pelo amor inculcado, pela felicidade que pelo apoio constante,

...un millón de gracias. 


\section{AGRADECIMENTOS}

- Ao Prof. Dr. Ricardo Antunes de Azevedo por permitir-me trabalhar em tão prestigioso laboratório, pela confiança depositada e inteires permanente na realização e conclusão deste trabalho de pesquisa.

- Ao Prof. Dr. Ladaslav Sodek pelo empo dedicado e por permitir a realização das análises de aminoácidos no seu laboratório.

- A conselho de Pós-graduação do Departamento de Genética por brindar-me a oportunidade de formar parte deste programa de estudos e contribuir a minha formação profissional.

- A meus pais por acreditar sempre na minha capacidade, pelo apoio constante e amor eterno dedicado.

- A meus irmãos, Vanesa e Daniel, pela força retribuída nestes anos longe de casa.

- A minha noiva e futura esposa Elizabeth, pelo amor dedicado, momento vividos e eternos momentos que compartilharemos juntos.

- Aos amigos de sempre: Luis, José Luis, Alexis, Esteban e Guilhermo.

- A minhas colegas de laboratório: Andreia, Berta, Flávia, Georgia, Liliane e Salete.

- Aos amigos colhidos no Brasil: Guilherme, José, Leandro, Leonardo, Renato, e Ricardo.

- A "los muchachos" da Fiaca Blues Band : Alejandro, Fabricio, Walter, Damián, Orlando e Arturo.

- A FAPESP pelo financiamento do Projeto de pesquisa.

- A CNpq pela ajuda econômica fornecida durante os dois anos de trabalho. 


\section{SUMÁRIO}

Página

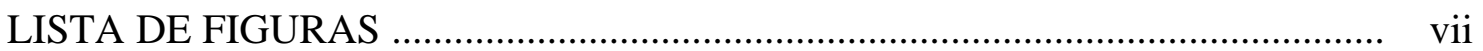

LISTA DE TABELAS .......................................................................... viii

LISTA DE ABREVIATURAS E SÍMBOLOS ............................................... ix

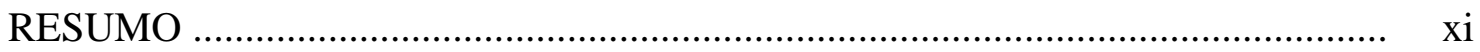

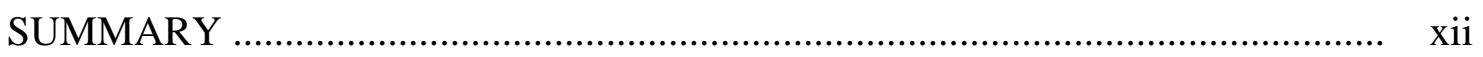

1 INTRODUÇÃ

2 REVISÃO DE LITERATURA ................................................................. 3

2.1 Via metabólica do ácido aspártico . ............................................................. 3

2.2 Regulação da via metabólica do ácido aspártico .............................................. 5

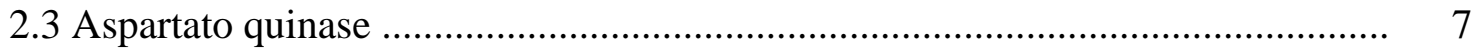

2.4 Enzima aspartato quinase - homoserina desidrogenase ................................. 11

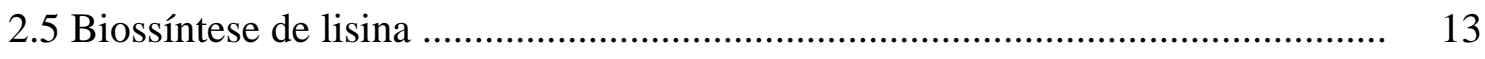

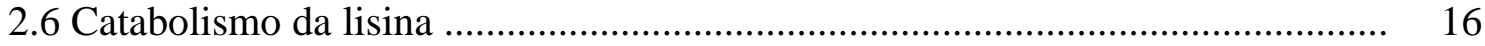

2.7 Análise de plantas transgênicas ................................................................ 24

2.8 Genes, mRNAs e proteínas envolvidas no metabolismo da lisina ...................... 29

2.9 Atividade do fator de transcrição Opaco- 2 .................................................... 35

2.10 Proteínas zeínas ..................................................................................... 40

2.11 Propriedades e caraterísticas dos mutantes de milho opaco e floury ................. 41

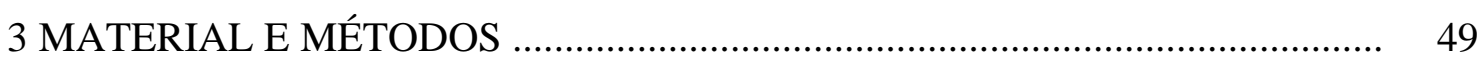

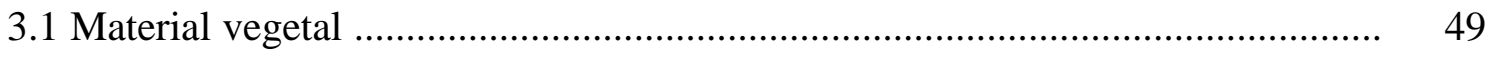

3.2 Extração de aminoácidos para análises por cromatografia em camada delgada ................................................................................. 50

3.3 Análise de aminoácidos por cromatografia em camada delgada ...................... 50 
3.4 Extração de aminoácidos para análise por cromatografia

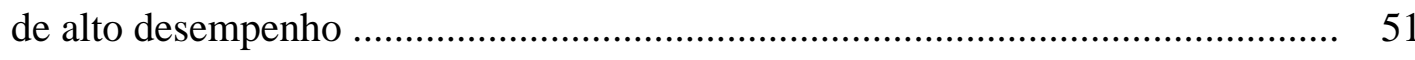

3.5 Análise de aminoácidos livres por cromatografia

líquida de alto desempenho ..................................................................... 51

3.6 Análises estatísticas .............................................................................. 52

4 RESULTADOS E DISCUSSÃO …............................................................ 53

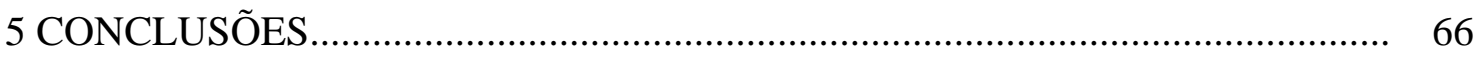

REFERÊNCIAS BIBLIOGRÁFICAS _..................................................... 67

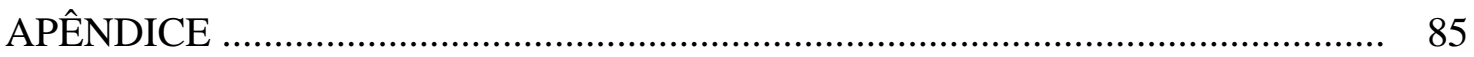




\section{LISTA DE FIGURAS}

Página

1 Via metabólica do ácido aspártico

06

2 Processo de degradação da lisina. 1) Lisina Oxoglutarato Reductase (LOR); 2) Sacaropina Desidrogenase (SDH); 3 ) Acido Aminoadípico Semialdeído Desidrogenase (AADH); 4) Ácido Aminoadípico Aminotransferase (AAA); 5) Transaminase de $\alpha$-aminoácidos. Abreviações: $\alpha$-kA, $\alpha$-ketoácidos; $\alpha$-AA, $\alpha$-aminoácidos

3 Regulação pós-traducional da enzima bifuncional LOR-SDH. Papel regulatório do $\mathrm{Ca}^{+2}$ e da fosforilação (promovida por Caseína Quinase-CK) provávelmente dependente dos níveis de lisina no citosol. LCP- proteínas que incorporam lisina. (Arruda et al., 2000) ....

4 Estruturas dos genes lor-sdh de milho e Arabidopsis. (Arruda et al., 2000)

5 Análise de lisina solúvel de anteras de milhos selvagens e mutantes por TLC. Lys: lisina. N6: variedade da ESALQ. Genótipos controles, 1 (W22), 2 (Oh43), 3 (WT3), 4 (B79) e 5 (B37). Genótipos mutantes: I (o1), II (o2), III (o5), IV (o7), V (o10), VI (o11), VII (o13), VIII (fl1), IX (fl2) e X (fl3) 


\section{LISTA DE TABELAS}

Página

1 Níveis de aminoácidos solúveis totais, lisina, treonina e metionina, em sementes maduras de genótipos de milho selvagens e mutantes. Os dados foram expressados em valores absolutos (nmol/ml). Análise de Variância $(\mathrm{y}=\log \mathrm{x}+10)$

2 Níveis de lisina, metionina e treonina solúveis em genótipos de milho selvagens e mutantes. Os dados expressos em valores relativos (\% mol).

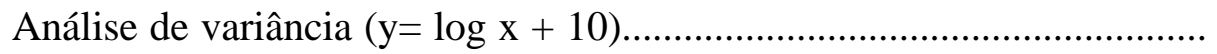

3 Médias de aminoácidos solúveis totais em genótipos de milho selvagens e mutantes. Os dados foram expressos em valores absolutos $(\mathrm{nmol} / \mathrm{ml})$. Diferenças significativas foram analisados pelo teste de Duncan

4 Médias de metionina solúvel em genótipos de milho selvagens e mutantes. Os dados foram expressados em valores absolutos (nmol/ml). Diferenças significativas foram analisadas por teste de Duncan

5 Médias de metionina solúvel em genótipos de milho selvagens e mutantes. Os dados foram expressados em valores relativos (\% mol). Diferenças significativas foram analisadas pelo teste de Duncan 


\section{LISTA DE ABREVIATURAS E SÍMBOLOS}

AAA - Ácido Aminoadípico Aminotransferase

AADH - Ácido Aminoadípico Semialdeído Desidrogenase

ADP - Difosfato de adenosina

AEC - S-2-aminoetil-L-cisteína

AK - Aspartato Quinase

AKI-HSDHI - Peptídeo Bifuncional AK-HSDH

ASA - Aspartato Semialdeído

ATP - Trifosfato de Adenosina

CaMV - Vírus do mosaico da couve flor

cDNA - DNA Complementar

CK - Caseina Quinase

CyPPDK - Enzima Ortofosfato Diquinase citosólica

CYS - Cisteína

DAA - Dias Após Antése

DAP - Dias Após Polinização

DHDPS - Dehidrodipicolinato Sintase

DNA - Ácido desoxirribonucléico

EGTA - Etileno Glicol - bis ( $\beta$-aminoetil éter).

GUS - gene uidA de E. coli que codifica para a enzima $\beta$-glucuronidase

HK - Homoserina Kinase

HPLC - Cromatografia Líquida de Alta Eficiência

HSDH - Homoserina Desidrogenase

HSP-70 - Proteína de Choque Térmico 
$\mathrm{I}_{50}$ - Índice de inibição do $50 \%$ de atividade enzimática.

$\mathrm{Km}$ - constante cinética de Michaelis - Menten.

LOR - Lisina Oxoglutarato Redutase

LOR-SDH - Peptídeo Bifuncional LOR-SDH

LT- Lisina + Treonina

LYS - Lisina

$\mathrm{Mr}$ - Massa relativa

mRNA - Ácido Ribonucléico mensageiro

NADH - Nicotinamida Adenina Dinucleótido (forma reduzida).

$\mathrm{NADP}^{+}$- Fosfato de Nicotinamida Adenina Dinucleotídeo (forma oxidada).

NADPH - Fosfato de Nicotinamida Adenina Dinucleotídeo (forma reduzida).

OPA - oftaldeído.

PAGE - Eletroforese em Gel de Poliacrilamida

PBF - Fator Protéico que se liga a Caixa Prolamina (prolamin box-binding factor)

PDI - Enzima Fosfato Diquinase Isomerase

PEG - Polietilenoglicol

PEP - Fosfoenolpiruvato

Rbcs - Subunidade menor da Ribulosa 1,5 - Bifosfato Carboxilase

RE - Retículo Endoplasmático

RER - Retículo Endoplasmático Rugoso

RIPs - Proteínas que inibem ribossomos

RT-PCR - Reação em Cadeia da Polimerase - Transriptase Reversa

SAM - S-adenosil metionina

SDH - sacaropina Desidrogenase

SDS-PAGE - Dodecil Sulfeto de Sódio - Eletroforese em Gel de Poliacrilamida

TDH- Treonina Desidratase

TLC - Cromatografia de Camada Delgada

TS - Treonina Sintase

UDP - Difosfato de Uridina

UDP-GT - Glucosil Transferse de Difosfato de uridina. 


\title{
QUANTIFICAÇÃO DE AMINOÁCIDOS SOLÚVEIS EM MUTANTES DE ENDOSPERMA DE MILHO
}

\author{
Autor: ALEJANDRO ALBERTO TORO \\ Orientador: Prof. RICARDO ANTUNES DE AZEVEDO
}

\section{RESUMO}

A principal fonte de proteínas para alimentação humana e animal é fornecida pelas sementes de cereais e leguminosas. O conteúdo de aminoácidos solúveis em endospermas de milho normal e mutantes opaco-2 e floury foram determinadas por HPLC. A análise indicou que a concentração total de aminoácidos solúveis variou entre os mutantes e seus tipos selvagens. Nos mutantes o10, oll e $o 13$, as concentrações foram aumentadas significativamente quando comparadas ao tipo selvagem W22, enquanto os mutantes $o 1, o 2, o 13, f l 1$ e $f l 2$ exibiram baixas concentrações em relação ao seu respectivo tipo selvagem Oh43. Resultados similares foram obtidos para os mutantes o5, o7 e fl3 em relação aos seus tipos selvagens (B79, B37 e WT3, respectivamente). Para metionina, o mutante $o 2$ e o tipo selvagem Oh43 apresentaram as mais altas concentrações deste aminoácido. Diferenças significativas não foram observadas para os outros aminoácidos analisados, tais como lisina e treonina. Os resultados sugerem que as altas concentrações sugeridas originalmente para estes mutantes devem ser devidas aos níveis destes aminoácidos incorporados nas proteínas de reserva, mas não na forma solúvel. 


\title{
SOLUBLE AMINO ACIDS QUANTIFI CATION IN MAIZE ENDOSPERM MUTANTS
}

\author{
Author: ALEJANDRO ALBERTO TORO \\ Supervisor: Prof. RICARDO ANTUNES DE AZEVEDO
}

\begin{abstract}
For human nutrition the main source of vegetable proteins are cereal and legume seeds. The content of total soluble amino acids in mature endosperms of wildtype and maize opaque and floury mutants have been determined by HPLC. The total absolute concentration of soluble amino acids among the mutants and their wild-type counterparts varied depending on the mutant. In the o10, o11 and o13 mutants the concentrations were significantly increased when compared to their wild-type counterpart W22, whereas the mutants o1, o2, o13, fll and $f l 2$ exhibited lower concentrations when compared to the wild-type Oh43, Similar results were observed for o5, o7 and $f l 3$ in relation to their specific wild-type counterparts (B79, B37 and WT3, respectively). For soluble methionine content, o2 and Oh43 exhibited the highest concentrations. Significant differences were not observed for other amino acids such as lysine and threonine. The results suggest that the high-lysine concentrations indicated originally for these mutants must be due to the amino acids incorporated into storage proteins, but not in the soluble form.
\end{abstract}




\section{INTRODUÇÃO}

A principal fonte de proteínas das plantas são as sementes de leguminosas e cereais. Dentre os cereais, o milho representa a base alimentar da grande maioria da população dos países da América Latina, África e Ásia. O Brasil é um dos principais produtores de milho no mundo, registrando uma produção de $33.038 .068 \mathrm{Mt}$, como consta nos arquivos da FAO de 2000. No entanto, milho é relativamente pobre em qualidade de proteínas, devido ao fato de apresentar quantidades limitantes de dois aminoácidos essenciais, lisina e triptofano (Bressani et al., 1991).

Dos 20 aminoácidos normalmente incorporados nas proteínas, somente 11 podem ser sintetizados por animais adultos. Os restante 9 aminoácidos, denominados essenciais devem ser subministrados na dieta. As plantas e a maioria das bactérias e fungos apresentam a capacidade de sintetizar os 20 aminoácidos, quando fornecidos eles com uma fonte adequada de carbono e nitrogênio inorgânico. Quatro de esses aminoácidos, lisina, treonina, metionina e isoleucina, são sintetizados através de uma rota metabólica que tem como precursor o ácido aspártico (Azevedo et al., 1997). Desafortunadamente os cereais são deficientes em lisina e treonina e legumes são deficientes em metionina (Azevedo et al., 1997).

As proteínas de reserva das semente servem como uma fonte primordial de substancias alimentícias que promovem a germinação e o desenvolvimento das plântulas. Os componentes de ditas proteínas de reserva são os responsáveis por determinar a qualidade nutricional do grão na alimentação de animais não ruminantes (Balconi et al., 1998). 
Numerosas mutações, conhecidas como opaco e floury, afetam a sínteses de proteínas de reserva no endosperma de milho (Mertz et al., 1964, Nelson et al., 1965). Conteúdo incrementado de lisina e triptofano foi observado na composição de proteínas do endosperma de milho mutante opaco-2 (o2). O gene homozigoto recessivo para o2 limita a sínteses de proteínas zeínas que contém pouca lisina e triptofano e um incremento pleiotrópico das proteínas não-zeínas que contém níveis elevados de lisina e triptofano no endosperma (Habben et al., 1993).

A utilização na agricultura do milho o2 foi limitada devido a uma baixa produtividade e características indesejáveis das sementes, como grãos macios e farinados que retém umidade e dificulta o armazenamento. Isto, contribui com uma considerável susceptibilidade a insetos, doenças e aflatoxina, e dano mecánico durante a manipulação e a colheita dos grãos.

O entendimento dos processos de sínteses e degradação de lisina em plantas, é de vital importância devido a concentração limitada de este aminoácido essencial, numa das principais fontes de alimento, os cereais, como também a análises do conteúdo de aminoácidos solúveis, produtos da via metabólica do ácido aspártico, em sementes de milho, permitiria compreender mutantes opaco e floury de milho. 


\title{
2 REVISÃO DE LITERATURA
}

\author{
Via metabólica do ácido aspártico
}

A via metabólica do ácido aspártico se inicia com o ácido aspártico ou aspartato (Figura 1), o primeiro composto estável com quatro carbonos, proveniente do Ciclo de Krebs, que será a base do esqueleto dos aminoácidos formados na via.

A primeira reação enzimática ocorre pela fosforilação do aspartato formando o $\beta$ aspartil fosfato, reação catalisada pela enzima Aspartato Quinase (AK). Seguidamente o $\beta$-aspartil fosfato é convertido a $\beta$-aspartil semialdeído, pela ação da enzima Aspartato Semialdeído Desidrogenase. Até esse ponto a via é comum para os quatro aminoácidos nela formados e a partir daí se ramifica em dois caminhos. Um deles origina o aminoácido lisina e outro os aminoácidos treonina, isoleucina e metionina. Este último caminho por sua vez, se ramifica em outros dois, um que origina o aminoácido metionina e outro que origina os aminoácidos treonina e isoleucina.

$\mathrm{Na}$ via de síntese de lisina o $\beta$-aspartil semialdeído é convertido a 2,3dihidropicolinato pela enzima Dihidrodipicolinato Sintase (DHDPS), e depois a piperidina-2,6-dicarboxilato pela Dihidrodipicolinato Redutase. Após esta etapa, a enzima Piperidina Descarboxilase Acilase forma o N-acil-2-amino-6-oxopimelato. Em seguida são adicionados nitrogênios ao esqueleto de carbono, pela enzima Acildiaminopimelato Aminotranferase e logo pela Diacilaminopimelato Deacilase. 
Modificações finais são realizadas pelas enzimas Diaminopimelato Epimerase e Diaminopimelato Descarboxilase, originando o aminoácido lisina.

A partir do $\beta$-aspartil semialdeído a via se divide no ramo que origina os aminoácidos treonina e isoleucina. Primeiramente, este composto é reduzido a homoserina pela ação da enzima Homoserina Desidrogenase (HSDH) sendo depois fosforilado a O-fosfohomoserina pela enzima Homoserina Quinase (HK). A última reação, catalisada pela enzima Treonina Sintase (TS), dá origem ao aminoácido treonina.

A treonina serve como substrato para a reação da enzima Treonina Desidratase (TDH), sendo convertida a 2-oxobutirato. A enzima Acetolato Sintase, forma o 2acetohidroxibutirato que seguidamente é convertido em 2',3-dihidroximetilvalerato pela ação da enzima Acetohidroxato Redutoisomerase. Este composto é desidratado a 2-oxometilvalerato pela enzima Dehidroxato Desidratase. Finalmente a ação da enzima Aminotransferase de cadeia ramificada, da origem ao aminoácido isoleucina.

Da síntese da O-fosfohomoserina, segue uma ramificação que leva a formação do aminoácido metionina. A primeira enzima envolvida exclusivamente na síntese de metionina é a enzima Cistationina- $\gamma$-Sintase, que leva a formação de cistationina. Este composto é transformado na sequência em homocisteína pela enzima Cistationina- $\beta$ liase e em seguida em metionina pela enzima Metionina Sintase. A metionina origina o composto S-adenosilmetionina (SAM) pela ação da enzima Metionina Adenosiltransferase.

As enzimas Lisina Oxoglutarato Redutase (LOR) e Sacaropina Desidrogenase (SDH) estão representadas na via metabólica do ácido aspártico por participarem na via de degradação da lisina. A degradação de lisina foi estudada em bactérias, fungos, plantas e animais e quatro vias catabólicas diferentes foram encontradas nos diferentes organismos estudados. Para mamíferos e plantas, foi determinado que a via de catabolismo mais importante envolve a formação do ácido $\alpha$-aminoadípico (Nigan \& Connel, 1963). A lisina é condensada juntamente com o $\alpha$-cetoglutarato para a formação de sacaropina, reação catalisada pela LOR. A sacaropina é então degradada a $\alpha$ aminoadípico- $\gamma$-semialdeído e ácido glutâmico pela ação da SDH. 
A maioria das enzimas envolvidas na síntese de lisina e treonina foram localizadas em plastídios. Analises de seqüências de DNA clonado confirmaram que estas enzimas são sintetizadas com peptídeos trânsitos que direcionam a proteína primaria dentro do plastídio (Kaneko et al., 1990; Frisch et al., 1991; Weisemann \& Matthews, 1993; Ghislain et al., 1994; Muehlbauer et al., 1994; Dante et al., 1999). A reação ocorrendo dentro de dita organela tem senso biológico porque algumas das reações bioquímicas requer energia que é grandemente produzida no plastídio (Galili, 1995). No entanto, algumas das enzimas da via metabólica do ácido aspártico, particularmente aquelas envolvidas na síntese de metionina e SAM, estão localizadas no citosol (Galili, 1995).

\section{$\underline{\text { Regulação da via metabólica do ácido aspártico }}$}

Os aminoácidos essenciais, lisina, treonina, metionina e isoleucina são sintetizados em plantas por um processo complexo que apresenta o ácido aspártico como precursor (Azevedo et al., 1997). A rota metabólica do aspartato tem sido objeto de inúmeras revisões (Lea et al., 1985; Bryan,1990).

A regulação da via metabólica do ácido aspártico se faz em determinados pontos chaves, através da regulação das enzimas que catalisam estes pontos. Em vias metabólicas multienzimáticas, onde o produto de uma enzima se torna o substrato da

próxima, a primeira enzima da sequiência normalmente atua como reguladora da velocidade de todo o sistema, sendo chamada de enzima regulatória.

A regulação das enzimas é realizada por ativação/inibição dos produtos finais, diretos ou indiretos, da atividade da enzima; processo chamado de retroalimentação positiva/retroalimentação negativa, originada da palavra inglesa "feedback" (Figura 1). 


\section{CICLO DE KREBS}

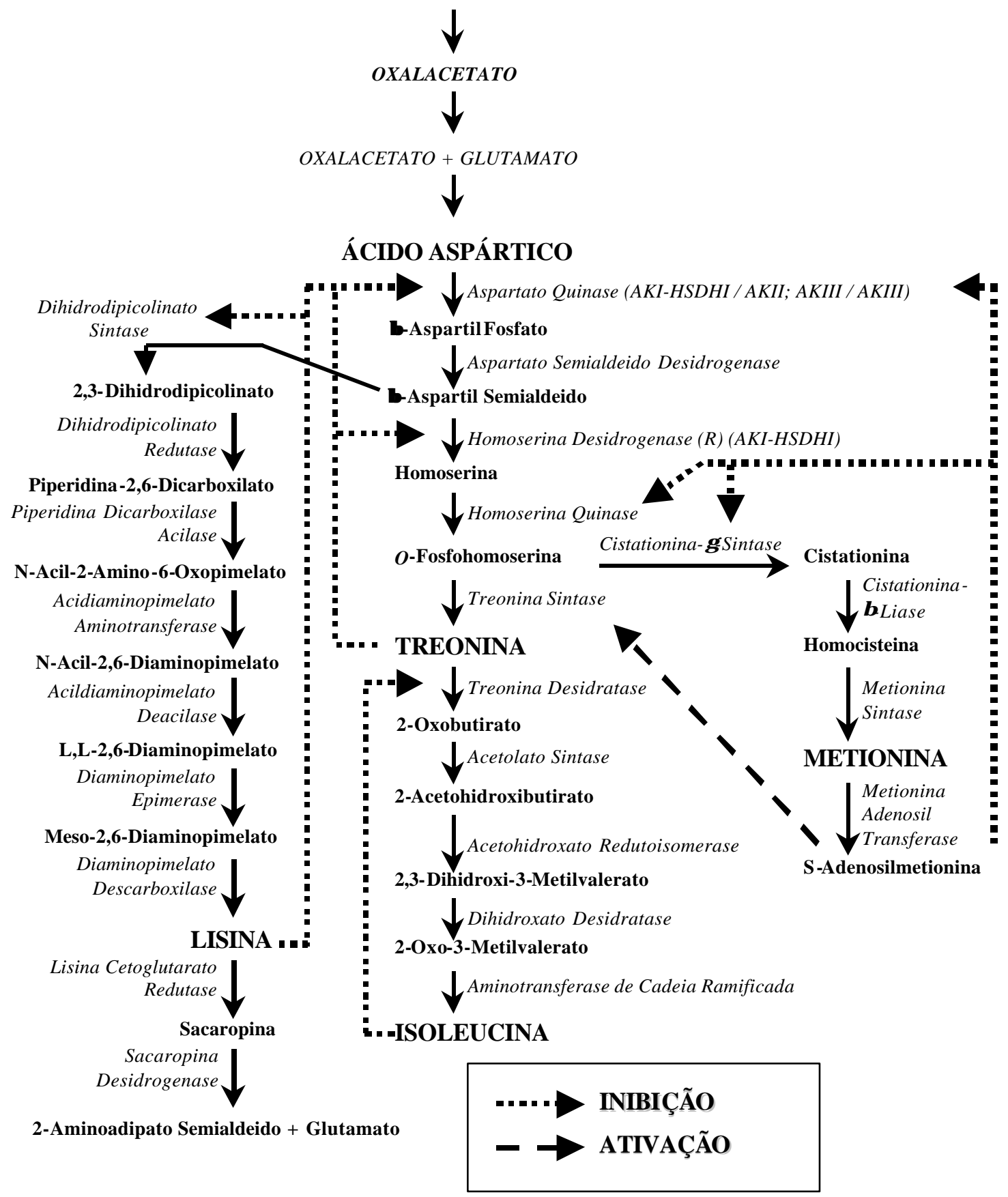

Figura 1- Via Metabólica do ácido aspártico. 


\section{Aspartato quinase}

A aspartato quinase (AK) é a primeira enzima da rota catalisando a conversão de aspartato em $\beta$-aspartil fosfato. Em plantas, a AK tem sido identificada, parcialmente purificada e bioquímicamente caracterizada em várias espécies de cereais de importância econômica (Azevedo et al., 1997).

A AK foi primeiramente estudada em bactérias, sendo purificadas três diferentes isoenzimas e caraterizadas a nível bioquímico e molecular em Escherichia coli (Stadtman et al., 1961) na cepa K12 (Saint-Girons \& Margarita, 1978), e em Saccharomyces cerevisiae, através de estudos de retroinibição da atividade da AK (Stadtman et al., 1961).

Em plantas, a AK foi estudada em milho (Bryan et al., 1970; Dotson et al., 1990; Azevedo et al., 1992a; Azevedo et al., 1992b; Brenecke et al., 1996), cevada (Aarnes, 1977; Bright et al., 1982a; Arruda et al., 1984), cenoura (Davies \& Miflin, 1978; Matthews \& Widholm, 1979a; Relton et al., 1988), soja (Matthews \& Widholm, 1979b) e arroz (Shaw \& Khu, 1984; Teixeira et al., 1998; Lugli et al., 2000). A regulação da atividade da enzima tem sido relatada ocorrer por retroinibição, utilizando lisina, treonina e metionina como substratos. Foram caraterizadas distintas isoenzimas de AK mostrando serem retroinibidas por lisina, treonina ou sinergísticamente por lisina e SAM. Pela retroinibição da atividade da AK, lisina e treonina podem regular sua própria síntese desde que ambas derivem do produto da atividade da $\mathrm{AK}$, o $\beta$-aspartil fosfato (Azevedo et al., 1997).

A AK foi extraída pela primeira vez em plantas, a partir, de hipocótilos de milho por Bryan et al. (1970). A atividade da enzima foi detectada a partir de extratos parcialmente purificados por precipitação com sulfato de amônio seguida de diálise. A enzima mostrou susceptibilidade a inibição por lisina e foi estimulada por alanina, valina e isoleucina.

Davies \& Miflin (1977), em células em suspensão de cenoura (Daucus carota L), purificaram parcialmente a atividade da AK em coluna de troca iônica. Observaram que 
baixas concentrações de treonina $(1 \mathrm{mM})$ foram capazes de inibir a atividade enzimática, como também quando usadas concentrações maiores de lisina $(5 \mathrm{mM})$.

Davies \& Miflin (1978), conseguiram isolar por filtração em gel dois picos de atividade de AK, um sensível a inibição por lisina e outro sensível a inibição por treonina, sugerindo a existência de duas isoenzimas da AK independentemente reguladas.

Rognes et al. (1980), trabalhando com AK em cevada (Hordeum vulgare L), encontrou um novo mecanismo de regulação para $\mathrm{AK}$, sendo sua atividade inibida pelo efeito sinergístico da SAM com a lisina.

Shaw \& Ku (1984), purificaram e identificaram a atividade da AK em folhas e plântulas de arroz (Oryza sativa L), observando que a enzima foi apenas inibida pela lisina para uma concentração de $10 \mathrm{mM}$.

Azevedo et al. (1992a), estudando células em suspensão de milho, identificaram três isoenzimas da AK com susceptibilidade diferencial a inibição por lisina ou treonina. A purificação realizada por cromatografía de troca iónica, filtração em gel e eletroforese PAGE não denaturante, revelaram para a atividade de $\mathrm{AK}$ dois picos, o primeiro deles referentes as isoenzimas sensíveis a treonina e o segundo a isoenzima sensível a lisina. Este último, mediante ensaios de atividade na presença de lisina e SAM, pôde ser desmembrado em duas isoformas sensíveis a lisina.

Teixeira et al. (1998), informaram purificação parcial das atividades de duas isoenzimas de $\mathrm{AK}$, por cromatografia de troca iónica, de sementes imaturas de arroz IAC-165. O primeiro pico em ordem de eluição correspondia a AK sensível a treonina (186 kDa), enquanto que o segundo a AK inibida por lisina (167 kDa). A caraterização bioquímica revelou que um $\mathrm{pH} 7.4$ e uma temperatura próxima aos $35^{\circ} \mathrm{C}$ foram ideais para atividade total da AK, com uma combinação de $20 \mathrm{mmol} / \mathrm{L}$ ATP e 12,5 mmol/L de sulfato de amônio, produzindo altos níveis de atividade da enzima.

Lugli et al. (2000), trabalhando com sementes imaturas de arroz IAC-165, verificaram que a atividade da AK sensível a treonina não foi alterada significativamente na presença de $\mathrm{Ca}^{+2}$, inibidores de calmodulina, SAM, S-(2-aminoetil)-L-cisteína (AEC), valina, metionina ou concentrações incrementadas de sais. Diferente 
comportamento foi observado para a atividade AK sensível a lisina, que foi estimulada com adição de metionina ou valina. No entanto, foi inibida quando combinada com $\mathrm{Ca}^{+2}$ + EGTA, SAM, SAM + lisina e KCl. Embora, tenha ocorrido um leve aumento na atividade de $\mathrm{AK}$ sensível a lisina na presencia de $\mathrm{Ca}^{+2}$, a magnitude da alteração não foi suficiente para indicar um papel regulatório do $\mathrm{Ca}^{+2}$ sobre a AK.

A distribuição das isoenzimas de $\mathrm{AK}$ sensíveis a treonina e lisina variam de acordo com o tecido e estado do desenvolvimento da planta (Lea et al., 1979). A AK sensível a lisina é normalmente predominante em plantas superiores, em tecidos em crescimento contínuo e representa $80 \%$ do total de atividade da enzima, diferente da isoenzima susceptível a retroinibição por treonina observada em cultura de calos e cotilédones de soja (Matthews \& Widholm, 1979), raiz de cenoura (Sakano \& Komamine, 1978) e sementes de Coix lacryma jobi (Lugli \& Azevedo, 1994 e 1995) representando entre 60-70 \% da atividade total de AK.

Previamente, numerosos trabalhos relataram o papel regulatório do $\mathrm{Ca}^{+2} \mathrm{e}$ calmodulina na atividade da AK em espinafre (Kochhar et al., 1986; Kochhar et al., 1987). Kochhar et al. (1987) purificaram AK de folhas de espinafre e determinaram que a calmodulina é uma das subunidades da AK sensível a lisina. Análises bioquímicos revelaram duas subunidades da isoenzima com $M_{r} 58000$ e 17000 , sendo a última a calmodulina. No entanto, Bonner et al. (1986) trabalhando com AK sensível a lisina altamente purificada de cenoura, não observaram influência do $\mathrm{Ca}^{+2}$ ou da calmodulina na atividade da AK. Azevedo et al. (1992c) testaram a atividade das isoenzimas purificadas de milho por Azevedo et al. (1992a) na presencia de $\mathrm{Ca}^{+2}$ e calmodulina de espinafre, verificando que as atividades das isoformas não foram afetadas pelos antagonistas de $\mathrm{Ca}^{+2}$, além da inibição normal produzida pela adição de lisina e treonina. Alias, as $M_{r}$ das subunidades da AK sensível a lisina, 71000 e 60000 de milho, não foram similares as encontradas por Kochhar et al. (1987) em espinafre.

Mutantes bioquímicos resistentes a combinações tóxicas de aminoácidos ou análogos de aminoácidos foram selecionados em milho (Hibberd \& Green, 1980; Hibberd \& Green, 1982; Azevedo et al., 1990), cevada (Bright et al., 1982a; Bright et al., 1982b), cenoura (Matthews et al., 1980) e Pennisetum americanum (Boyes \& Vasil, 
1987). Na maioria dos casos foi observado que as mutações produzem uma alteração na capacidade de união do aminoácido a enzima alvo (Hibberd \& Green, 1980; Matthews et al., 1980; Hibberd \& Green, 1982; Bright et al., 1982).

Hibberd et al. (1980) selecionaram in vitro linhas celulares de milho resistentes a lisina + treonina (LT). A atividade de AK do extrato bruto foi aproximadamente 8 vezes menos sensível a retroinibição por lisina do que $\mathrm{AK}$ de culturas não selecionadas susceptíveis a LT. Posteriormente, Hibberd \& Green (1982), obtiveram novas linhas mutantes de milho que apresentaram níveis até 100 vezes maiores de treonina solúvel em relação aos grãos das plantas selvagens e isto dependia do background e composição alélica do embrião e do endosperma. Recentemente, dois mutantes LT de milho que produziam níveis elevados de treonina foram observados, sendo as mutações controladas por loci não alélicos, ask1 e ask2 (Frisch \& Gengenbach, 1986).

Bright et al. (1982) selecionaram plantas de cevada na presença de LT e obtiveram mutantes que apresentavam $\mathrm{AK}$ com sensibilidade alterada a lisina e consequentemente acumulavam treonina na fração de aminoácidos solúveis de folhas e sementes. Embora, linhagens de milho e cevada resistentes a níveis elevados de lisina e treonina foram obtidas, ambos mutantes não acumularam lisina ou metionina.

Azevedo et al. (1990) realizaram estudos genéticos e bioquímicos de endospermas de plantas de milho Ltr*1/o2, codificando uma AK resistente a LT (askl). Determinaram que a presença do gene $L t r^{*} l$ aumentou os níveis de treonina solúvel em 45-144 vezes e de aminoácidos solúveis totais em 3-10 vezes, além de uma diminuição dos níveis de zeínas nos duplos mutantes trr $^{*} 1$ ltr $1 * 1 / 0202$ quando comparados com endospermas $o 2$ e normal. Isto demonstrou que o gene $L t r^{*} 1$ intensificou os efeitos do gene $o 2$.

O gene $L t r * 1$ foi localizado no braço curto de cromossomo 7 a uma distância de 10.6 centimorgans do gene $o 2$ (Azevedo et al., 1990), provavelmente do lado oposto do centrómero, próximo aos genes que codificam polipeptídeos zeínas (Ottoboni \& Stefferson, 1987), sendo que, alguns dos quais são regulados pelo gene $o 2$ (Burr \& Burr, 1982). No entanto, Ltr*1 é um gene estrutural que codifica uma AKII alterada, sendo 
desconhecido como poderia exercer um efeito de posição sobre o o2. Azevedo et al. (1990) sugerem que $o 2$ poderia controlar a expressão do gene askl.

Dotson et al. (1990) purificaram e caraterizaram AKs de plantas de milho A619 e mutantes derivados LT19 e LT20 (contendo os alelos Ask-LT19 e Ask2-LT20, respectivamente) para alta produção de treonina, lisina, metionina e isoleucina solúveis. Observaram que grãos homozigotos Ask2 apresentaram aumentos de 174-, 10-,13- e 2vezes destes aminoácidos quando comparados as plantas selvagens. Em milhos selvagens, o $\mathrm{f}_{0}$ da $\mathrm{AK}$ correspondeu para $10 \mu M$ de L-lisina. Em contraste, AK de heterozigotos Ask e homozigotos Ask2, apresentaram 50\% de inibição para 25 e $750 \mu M$ do aminoácido, respectivamente. Isto sugere que Ask e Ask2 seriam loci separados que codificam subunidades de AK reguladas por lisina em milho. Além disso, foi sugerido também que $\mathrm{AK}$ em homozigotos Ask2 de milho seria uma enzima heteromérica com dois polipeptídeos sensíveis a lisina derivados dos genes estruturais Ask e Ask2.

\section{$\underline{\text { Enzima aspartato quinase/homoserina desidrogenase }}$}

Homoserina desidrogenase (HSDH), catalisa a redução de aspartato semialdeído (ASA) para homoserina por NADPH, com NADH podendo servir também como substrato (Bryan, 1990) e esta localizada principalmente no cloroplasto. Estudos de localização intracelular, baseados em gradiente de sacarose, demonstraram que em milho as isoformas de HSDH se encontravam localizadas nos cloroplastos (Bryan et al., 1977).

Pelo menos dois tipos de isoenzimas para HSDH estão presentes em plantas, uma HSDH sensível e outra resistente a treonina (Aarnes \& Rognes, 1974; Grego et al., 1980; Sainis et al., 1981; Krishnaswamy \& Bryan, 1983; Krishnaswamy \& Bryan, 1986). 
Em milho, foi observado que a HSDH resistente a treonina apresenta uma $M_{r}$ 70000-80000 (Sainis et al., 1981). Em plântulas de milho, foi demonstrada a estabilidade da isoenzima resistente a treonina sob certas condições de extração, nas quais a HSDH sensível a lisina estava completamente inativa (Bryan \& Lochner, 1981).

A enzima HSDH sensível a lisina de milho apresenta uma $M_{r}$ 150000-190000 (Krishnaswamy \& Bryan, 1986) e sua atividade foi grandemente estimulada por $\mathrm{K}^{+}$ (Grego et al., 1980).

Em E. coli foram identificadas duas enzimas bifuncionais, codificadas pelos gene thrA (AKI-HSDHI) e metL (AKII-HSDHII). A AKIII é codificada pelo gene lysC e não contém atividade de HSDH. A AKI-HSDHI é inibida por treonina, entretanto a AKIIHSDHII é inibida por metionina (Patte et al., 1996). Em Saccharomyces cerevisiae (Rafalski \& Falco, 1988), as atividades HSDH e AK residem sobre proteínas separadas codificadas por genes diferentes.

Numerosos trabalhos tem informado sobre a existência de um polipeptídio bifuncional AK-HSDH em plantas (Wilson et al., 1991; Azevedo et al., 1992b; Teixeira et al., 1998). Clones de cDNA codificando para a AK-HSDH sensível a treonina, foram isolados a partir de cenoura (Weismann \& Matthews, 1993), milho (Muehlbauer et al., 1994) e soja (Matthews et al., 1992).

Aarnes \& Rognes (1974), trabalhando com ervilha, demonstraram a presença de duas isoformas de HSDH, uma sensível e outra resistente a inibição por treonina. A isoenzima sensível foi co-eluída com AK sensível a treonina, sugerindo pela primeira vez a existência de um polipetídio bifuncional AK-HSDH em plantas.

A evidência definitiva foi obtida por Wilson et al. (1991), que isolaram e caraterizaram um peptídio bifuncional AK-HSDH a partir de cultura de células de cenoura. Observaram também a coeluição das atividades das enzimas durante os passos de purificação e o paralelismo das bandas de atividade das enzimas quando migraram em PAGE não denaturante. Além disso, por seqüenciamento de aminoácidos observaram uma elevada homologia com a AKI-HSDHI de E.coli, embora a sensibilidade da AK para retroinibição não tenha sido bem entendida. 
Azevedo et al. (1992b) trabalhando com cultura de calos de milho Cat100-1, purificaram o polipeptídio bifuncional, e caraterizaram como AK e HSDH sensíveis a treonina, mediante co-purificação das atividades de AK e HSDH. A AK sensível a treonina apresentou um $M_{r}$ 180000, entretanto a HSDH resistente a treonina uma $M_{r}$ 70000 .

Teixeira et al. (1998) determinaram que o pico de atividade da isoenzima sensíveis a treonina de AK e HSDH, de sementes de arroz, co-purificaram. Independente do método de purificação empregados exibiram um $M_{r}$ de 186000 . A AK sensível a lisina mostrou uma $M_{r}$ de 167000 . Tais resultados, confirmam a presença em plantas superiores de isoformas de $\mathrm{AK}$, sensíveis a lisina e treonina e sugerem que um polipeptídeo bifuncional, contendo a AK-HSDH sensível a treonina, estão presentes em arroz.

Embora muitas plantas apresentam mais do que um gene $a k-h s d h$, em A. thaliana somente um simples gene foi detectado (Ghislain et al., 1994).

Zhu-Shimoni et al. (1997) media nte técnicas de hibridação "in situ" usando como sonda um cDNA $a k-h s d h$, estudaram os níveis de mRNA AK-HSDH em plantas de tabaco. Os autores observaram maior abundância de transcritos em folhas jovens e foram apenas detectados em folhas maduras. Os mRNAs foram também detectáveis em órgãos florais e em raízes, embora em níveis inferiores.

\section{$\underline{\text { Biossíntese de lisina }}$}

A DHDPS, primeira enzima da via de síntese de lisina pode ser fortemente inibida por este aminoácido (Kumpaisal et al., 1987). Embora, não tenha sido identificado isoformas para DHDPS, esta enzima desempenha o papel mais importante na regulação da síntese de lisina. 
$\mathrm{Na}$ maioria das bactérias e em plantas superiores, lisina, treonina, metionina e isoleucina são sintetizadas através da via do ácido aspártico (Galili, 1995; Azevedo et al., 1997). Duas enzimas da via, AK e DHDPS, são retroinibidas por lisina. A DHDPS é a primeira enzima do ramo da via que leva exclusivamente a síntese de lisina. A atividade da DHDPS é considerada o passo regulatório chave para síntese de lisina em plantas (Azevedo et al., 1997).

A DHDPS foi purificada a partir de trigo (Kumpaisal et al., 1987), tabaco (Ghislain et al., 1990), milho (Frisch et al., 1991), ervilha (Dereppe et al., 1992) e Coix lacryma jobi (Dante et al., 1999). cDNAs foram clonados a partir de várias espécies de plantas (Kaneko et al., 1990; Frisch et al., 1991; Vauterim \& Jacobs, 1994; Dante et al., 1999).

Sodek (1976) trabalhando com isótopos radiativos identificando o ácido aspártico $\left[4-{ }^{14} \mathrm{C}\right]$ e ácido diaminopimélico $\left[1,(7)-{ }^{14} \mathrm{C}\right]$, demonstrou que a lisina em plantas superiores é sintetizada através da via do ácido diaminopimélico. Por microinjeção direta em endosperma imaturo de milho (Zea mays L. cv. Maya o2), foi observado que o ${ }^{14} \mathrm{C}$ do ácido aspártico marcou para lisina, entre outros aminoácidos, e ${ }^{14} \mathrm{C}$ do ácido diaminopimélico foi convertido diretamente em lisina. Isto revelou que a síntese de lisina e outros aminoácidos ocorre também em endosperma.

Negrutiu et al. (1984) isolaram duas linhas mutantes de tabaco resistentes a AEC, um análogo da lisina, com aumento de 10 e 20 vezes na produção de lisina nas folhas das plantas regeneradas in vitro. Análise de mutantes mostraram que possuíam uma atividade DHDPS que foi menos sensível a retroinibição por lisina.

Galili (1995), observou que em plantas a DHDPS e particularmente sensível a retroinibição por lisina, apresentando um $\mathrm{I}_{0.5}$ entre $10-50 \mu \mathrm{M}$. A DHDPS é aproximadamente 10 vezes mais sensível a inibição por lisina do que $\mathrm{AK}\left(\mathrm{I}_{0.5}\right.$ entre 100$700 \mu \mathrm{M})$ e aproximadame nte 100 vezes mais sensível a inibição por lisina do que é a DHDPS de E. coli $\left(\mathrm{I}_{0.5}=1000\right)$.

Azevedo \& Arruda (1995), selecionaram plantas resistentes a AEC, por cultura in vitro de calos embriogênicos de milho Cat-100-1, que foram submetidas a mutagenesis com $\mathrm{NaN}_{3}$. A resistência foi condicionada por um gene dominante simples no mutante 
AEC-1 e um gene recessivo no mutante AEC-5. Embora, um pequeno mais consistente incremento nos níveis de lisina solúvel tenha sido observado nos endospermas, não foi tão pronunciado quanto o observado em tabaco (Negrutiu et al., 1984). Os autores sugerem que a AK das linhagens mutantes permaneceram sensíveis a retroinibição por lisina, consequentemente a disponibilidade do substrato para a DHDPS poderia estar limitado e portanto prevenindo a acumulação de lisina.

Dante et al. (1999) análisaram a expressão do gene DapA que codifica para a enzima DHDPS de Coix lacryma-jobi, e observaram aumento de mRNA DHDPS em coleoptiles, embriões imaturos e endosperma. Plântulas crescidas na escuridão apresentaram níveis diminuídos de mRNA. O padrão observado foi similar a acumulação de mRNA DHDPS em milho. A acumulação de mRNA DHDPS durante o desenvolvimento do embrião e o endosperma, em Coix e milho, foram altos nas etapas iniciais e diminuíam com o processo da maturação da semente. Em ambas espécies, usualmente embriões exibiram quantidades maiores de transcritos do que endospermas. No entanto, os níveis de mRNA DHDPS em endosperma de Coix decresciam abruptamente após $10 \mathrm{DAP}$, enquanto em milho os níveis dos transcritos permaneciam constantes durante todo o desenvolvimento. Para comparar o padrão de acumulação de mRNA DHDPS, os autores estudaram a expressão do gene DapA no mutante $o 2$ de milho F-352, e observaram que não foi afetado durante o desenvolvimento global da semente apresentando um leve decréscimo do mRNA DHDPS tanto no endosperma como no embrião.

O fenótipo anormal constatado em plantas transgênicas e nos mutantes selecionados que acumulam lisina podem ser comparados as alterações apresentadas por mutantes $o 2$ e b-32 de milho. Estes mutantes apresentam níveis mais altos de lisina no endosperma do que os milhos normais, porém também apresentam características agronômicas desfavoráveis como alteração da morfologia foliar, reduzida capacidade de produção e endosperma frágil susceptível ao ataque de fungos durante a estocagem do grão. 


\section{$\underline{\text { Catabolismo de lisina }}$}

A lisina é um dos aminoácidos essenciais mais importantes, sendo que os cereais possuem baixas concentração dele, embora representem uma importante fonte de alimento para animais e humanos. Por causa de sua relevância nutricional, numerosas investigações têm focalizado compreender os mecanismos regulatórios que controlam o acúmulo de lisina em sementes. Estes envolvem, complexos processos de síntese, incorporação em proteínas e degradação (Arruda et al., 2000).

O catabolismo da lisina em plantas é iniciado com as enzimas LOR e SDH, as quais apresentam domínios separados em um polipeptídio bifuncional LOR-SDH. A LOR condensa lisina e ácido $\alpha$-cetoglutarico para formar sacaropina. A sacaropina seguidamente é hidrolizada, pela ação da $\mathrm{SDH}$, originando $\alpha$-aminoadipico- $\delta$ semialdeido e ácido glutâmico. Estes dois passos podem ser vistos como uma típica reação de transaminação, na qual, o grupo amino da lisina é transferido ao ácido $\alpha$ cetoglutárico formando ácido glutâmico. Uma segunda molécula de ácido glutâmico é formada em uma reação catalisada pela enzima ácido $\alpha$-aminoadípico aminotrasferase (AAA), no qual o grupo $\alpha$-amino da lisina é transferido desde o ácido $\alpha$-aminoadipico para o ácido $\alpha$-cetoglutarico (Figura 2) (Arruda et al., 2000).

Em monocotiledôneas, como milho (Arruda et al., 1982; Arruda et al., 1983; Arruda \& Silva, 1983) e arroz (Gaziola et al., 1997), e em dicotiledôneas, como Arabidopsis (Tang et al., 1997), tabaco (Karchi et al., 1994) e soja (Miron et al., 1997), o catabolismo da lisina é realizado pela via da sacaropina, mas o papel fisiológico do catabolismo da lisina deve diferir entre as duas famílias de plantas.

Os primeiros estudos relacionados ao catabolismo da lisina em plantas superiores, envolveram a incorporação e metabolismo de aminoácidos marcados com isótopos ${ }^{14} \mathrm{C}$ de carbono, administrados em tecidos de plantas. 

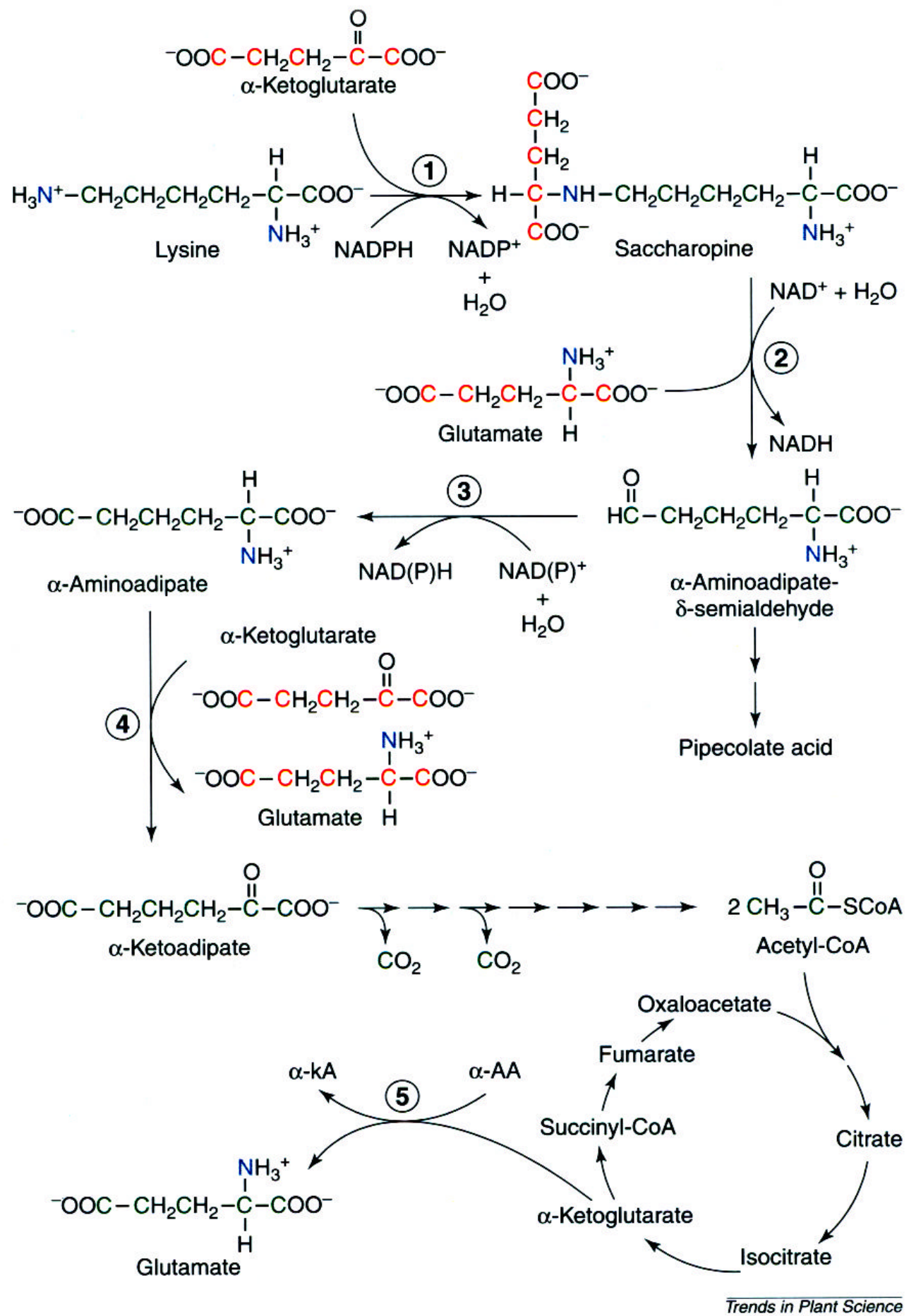

Figura 2 - Processo de degradação da lisina. 1) Lisina Oxoglutarato Reductase (LOR); 2) Sacaropina Desidrogenase (SDH); 3) Acido Aminoadípico Semialdeído Desidrogenase (AADH); 4) Ácido Aminoadípico Aminotransferase (AAA); 5) Transaminase de $\alpha$-aminoácidos. Abreviações: $\alpha$-kA, $\alpha$-ketoácidos; $\alpha$-AA, $\alpha$ aminoácidos. (Arruda et al., 2000). 
Nigan (1963), e Lawrence \& Grant (1964), administrando lisina marcada com ${ }^{14} \mathrm{C}\left({ }^{14} \mathrm{C}\right.$-lisina) em plantas de trigo, observaram a incorporação do ${ }^{14} \mathrm{C}$ em ácido $\alpha$ aminoadípico e ácido glutâmico.

Sodek \& Wilson (1970), trabalhando com plantas de milho suplementadas com ${ }^{14} \mathrm{C}$-lisina, observaram a incorporação de ${ }^{14} \mathrm{C}$ em sacaropina e ácido diaminopimélico.

Brandt (1975), analisando a incorporação de ${ }^{14} \mathrm{C}$-lisina em endosperma de milho o2 e normal, observou que no endosperma de plantas normais $14 \%$ do ${ }^{14} \mathrm{C}$ injetado foi transferido para ácido glutâmico e $8 \%$ para prolina. No entanto, no endosperma mutante, somente $3 \%$ do ${ }^{14} \mathrm{C}$ foi observado em ácido glutâmico, não observando-se a formação de prolina.

Silva \& Arruda (1979), analisaram o conteúdo de nitrogênio total e lisina no endosperma e na seiva do pedúnculo de espigas de plantas de milho sugary o2 (suo2) e também em plantas normais (SUO2). Observaram que os níveis de nitrogênio em ambos compartimentos diminuiu com o desenvolvimento da espiga. A lisina, ao contrario, na seiva do pedúnculo apresentou valores constantes. Finalmente, no endosperma normal os níveis de lisina diminuíram entre 7-35 DAP e no duplo mutante os níveis permaneceram quase constantes a partir de 21 DAP. Portanto, embora síntese de lisina possa ter ocorrido no endosperma, a maioria deve ter sido sintetizada em outros tecidos da planta e transportada para o endosperma em desenvolvimento. Seguidamente, os autores estimaram o fluxo de lisina da seiva para o endosperma imaturo de milho. Observaram no endosperma normal, um fluxo excessivo de lisina, implicando a necessidade de degradação desse aminoácido, o qual foi evidenciando em etapas primárias do desenvolvimento da semente. No duplo mutante, a taxa de lisina observada foi similar a taxa de lisina estimada e portanto, o catabolismo da lisina não seria necessário, exceto em estágios mais avançados do desenvolvimento da semente.

A primeira evidência enzimática do catabolismo da lisina em plantas, foi obtido pela demonstração da atividade da LOR em endosperma de milho em desenvolvimento pelo grupo de Arruda et al. (1982). Eles, caracterizaram e demonstraram atividade da LOR em endosperma de grãos imaturos de milho híbrido ML-2000 x ML-2001, com 30 DAP. No extrato parcialmente purificado a atividade da enzima foi específica para os 
substratos lisina, $\alpha$-cetoglutarato e NADPH, quando monitorada em espectrofotômetro. A identificação específica da atividade LOR, foi obtida através de cromatografia em camada delgada (TLC) do extrato ensaiado ou TLC adicionando ${ }^{14} \mathrm{C}$-lisina ao extrato, revelando o produto sacaropina por niidrina ou autoradiografía, respectivamente.

Arruda \& Silva (1983), purificaram parcialmente a LOR em grãos imaturos de milho, do híbrido ML649 x ML674, por fracionamento em sulfato de amônio e filtração em gel Shephadex G-25. Análises da atividade da enzima mostraram especificidade para lisina, 2-oxoglutarato e NADPH como substratos. Nenhum dos outros aminoácidos que constituem proteínas substituiu a lisina. Assim, os autores determinaram que a atividade de LOR aumentou com o desenvolvimento do grão, atingindo o pico máximo em 20 DAP, para logo diminuir progressivamente com a maturidade da semente. Esta observação foi correlacionada com o incremento da taxa total de nitrogênio e zeínas, coincidindo a atividade com o acúmulo máximo de nitrogênio e com a síntese de zeínas no endosperma.

Brochetto-Braga et al. (1992), obteve a purificação parcial da LOR por cromatografia de afinidade sobre sepharose azul CL-6B, a partir de linhas endogâmicas de milho L1038 e Cat-100-1, ambas homozigotas para o gene normal e o2. Por cromatografia em gel de poliacrilamida foi determinado uma $M_{r}$ 140000. A análise da atividade de LOR foi determinada por PAGE não denaturante. Os autores determinaram que sacaropina não é inibidor competitivo de $\alpha$-cetoglutarato, mas sim para lisina. A cinética observada, sugere um rápido equilíbrio por um mecanismo ordenado de união a enzima, onde a lisina seria o primeiro composto a unir-se, seguido por $\alpha$-cetoglutarato e $\mathrm{NADPH}$, com conseqüente liberação da $\mathrm{NADP}^{+}$e sacaropina. Também foi observado que a atividade da LOR mostrou uma correlação entre o aumento de atividade e a acumulação de proteínas zeínas. A atividade máxima foi observada para 20 DAP e o máximo de acumulação para 25 DAP, respectivamente, em ambos genótipos. No entanto, as linhas $o 2$ apresentaram quantidade de zeínas duas vezes menor e atividade enzimática três vezes menor, sendo isto mais acentuado para L1038. Como conseqüência desta relação os autores sugerem que os genes codificando para LOR poderiam estar sob o controle do produto do gene $o 2$. 
Gonçalvez-Butruille et al. (1996), trabalhando com milho híbrido F-352, purificaram a enzima bifuncional LOR-SDH. Ambas atividades enzimáticas copurificaram sobre DEAE e filtração em coluna de gel para um $M_{r} 260 \mathrm{kD}$. A atividade específica LOR e SDH foi determinada separadamente por PAGE em presença de lisina ou de sacaropina, apresentando bandas simples com mobilidade similar. Os produtos da atividade de LOR e SDH foram identificados por TLC.

Tang et al. (1997), trabalhando com cultura de células de Arabidopsis, purificaram um polipeptídio bifuncional LOR-SDH e uma isoenzima monofuncional $\mathrm{SDH}$, primeiramente fracionadas por polietilenglicol (PEG) e posterior eluição em coluna de troca iônica. Mediante o uso de sondas de RNA, marcadas com digoxigenina, nos domínios LOR e SDH do LOR-SDH cDNA de Arabidopsis, demonstraram que os mRNAs de LOR e SDH foram abundantes em óvulos e tecido vascular de filamentos de anteras, mas não em grãos de pólen. Em sementes, imaturas e desenvolvidas, sinais de hibridização foram observados no embrião e nos tecidos externos do endosperma. Os resultados indicam que a regulação da expressão dos gene lor-sdh e $s d h$ seria tecidoespecífica durante o desenvolvimento da planta.

Kemper et al. (1999), analisando a atividade de LOR-SDH durante o desenvolvimento de endosperma de milho híbrido F-352 e mutante F-352o2, observaram que no endosperma normal os níveis de atividade e os níveis de proteínas alcançaram o máximo em 20 DAP, entretanto no endosperma mutante níveis máximos coincidiram em 25 DAP. Analisando a expressão do gene $l o r-s d h$, observaram que no genótipo normal a quantidade máxima de mRNA foi observada em 15 DAP e decresceu com o desenvolvimento. Entretanto no mutante, foi entre 20-25 DAP somente. Os autores concluem que a atividade diminuída da enzima é devido a níveis reduzidos do polipeptídeo como conseqüência da reduzida acumulação de transcritos do gene lor-sdh no endosperma 02 . Por imunomarcação, foi demostrado que o polipeptídio LOR-SDH expressou mais intensamente nas células da sub-aleurona e a atividade LOR e SDH foram somente detectadas no citosol. Não foi observada atividade da enzima nas células da aleurona. Mediante técnicas de hibridação in situ, foi determinado que o mRNA 
LOR-SDH foi observado principalmente no endosperma. Não foi detectado hibridação nos tecidos do embrião.

Em milho, como a síntese de proteínas zeínas não demanda lisina, provavelmente o excesso deste aminoácido seria degradado. De fato, os genes que codificam para a família de zeínas e o gene codificando a enzima LOR-SDH de milho, foram demostrados ser controlados pelo fator de transcrição O2 (Kemper et al., 1999). Então ao aumentar a taxa de síntese de zeínas, devido a ativação transcricional de seus genes pelo $\mathrm{O} 2$, a atividade de LOR-SDH incrementaria concomitantemente (Figura 3), o que resultaria na degradação da lisina em excesso nas células do endosperma (Arruda et al., 2000).

Miron et al. (2000), purificaram e caraterizaram LOR-SDH a partir de sementes imaturas de soja. Frações altamente purificadas em coluna de sepharose mostraram um peptídeo de $123 \mathrm{kDa}$, similar aos previamente informados para milho com $125 \mathrm{kDa}$ (Goncalves-Butruille et al., 1996) e Arabidopsis com 118 kDa (Tang et al., 1997). As enzimas LOR e SDH do polipeptídio apresentaram atividade máxima em pH 7.2 e pH 9.0, respectivamente. Os autores analisaram a cinética das enzimas e concluíram que a LOR representaria o passo limitante que regula o catabolismo de lisina in vivo.

Gaziola et al. (2000), purificaram a enzima LOR-SDH a partir de sementes imaturas de arroz (estágio milky). Um aumento de $87 \%$ na atividade de LOR foi observada em pH 7.0, comparada ao $\mathrm{pH} 7.4$ usado para sementes de arroz em outro trabalho, no qual similarmente, um incremento de $40 \%$ da atividade de SDH foi observado em $\mathrm{pH}$ 8.0, comparado ao $\mathrm{pH} 8.4$ previamente usado para SDH em sementes de arroz (Gaziola et al., 1997). Atividade do domínio LOR, do polipeptídeo, foi modulada por $\mathrm{Ca}^{+2}$ e baixas concentrações de $\mathrm{KCl}(100 \mathrm{mM})$, no entanto não produziram efeito sobre a atividade de SDH. O efeito da AEC sobre a atividade de LOR, mostro ocorrer devido a atuar como um substrato da enzima, o qual pôde substituir pouco eficientemente a lisina, mas foi também capaz de inibir a atividade de LOR em elevadas concentrações. Finalmente, foi determinado neste trabalho que SAM não produz efeito algum sobre a atividade de LOR e SDH sendo sugerido claramente que SAM não está envolvido na degradação de lisina. 
O papel regulador do $\mathrm{Ca}^{+2}$ nas enzimas envolvidas no metabolismo de lisina foi proposto por vários autores (Arruda et al., 2000; Kemper et al., 1998). No entanto, para algumas espécies de plantas não foi observada a modulação das enzimas pelo $\mathrm{Ca}^{+2}$ (Bonner et al., 1986; Azevedo et al., 1992b; Lugli et al., 2000). No milho a atividade de LOR, mas não $\mathrm{SDH}$, foram mostradas sendo reguladas pelo $\mathrm{Ca}^{+2}$ e condições de elevada força iônica (Kemper et al., 1998). A regulação da atividade de LOR pelo $\mathrm{Ca}^{+2}$, seria devido a modulação de um domínio inibitório existente na enzima (Kemper et al., 1998). Um sítio de união para $\mathrm{Ca}^{+2}$, está presente nas sequiências de aminoácidos das proteínas LOR de milho e Arabidopsis (Tang et al., 1999; Kemper et al., 1999). Análises da cinética mostraram um $\mathrm{K}_{\mathrm{m}}$ elevado para AEC comparado a lisina, o que refletiria um sítio de baixa afinidade de união para AEC (Gaziola et al., 2000). Em arroz, foi observado que somente a atividade de LOR é regulada por $\mathrm{Ca}^{+2}$, mas não SDH (Gaziola et al., 2000), como também descrito em milho (Kemper et al., 1998). Embora, o mecanismo geral de regulação da enzima LOR-SDH em milho e arroz, sejam muito similares, quando usadas concentrações similares de $\mathrm{Ca}^{+2}$ e EGTA, eles basicamente diferem sobre a extensão do efeito do $\mathrm{Ca}^{+2}$, de modo que a adição de EGTA para ensaios de atividade de LOR de arroz reduz a atividade em $21 \%$ (Gaziola et al., 2000), sendo que na LOR de milho a redução pode atingir até $70 \%$ dependendo da concentração de sais no sistema tampão (Kemper et al., 1998). Os resultados sugerem que a regulação da atividade de $\mathrm{LOR}$ pelo $\mathrm{Ca}^{+2}$, seria uma caraterística comum em plantas.

Por tanto, nos endospermas de milhos $o 2$, mutantes com níveis aumentados de lisina, as atividades de LOR e SDH são mais baixas do que as detectadas em endosperma de milho normal (Silva \& Arruda, 1979), e sugere que a degradação da lisina seria um passo importante na regulação da quantidade de lisina final encontrada no endosperma.

Avanços na biotecnologia têm demostrado que os níveis dos aminoácidos lisina e treonina solúvel podem ser modificados com a obtenção de plantas transgênicas expressando formas das enzimas AK e DHDPS de bactérias insensíveis à inibição por lisina. 


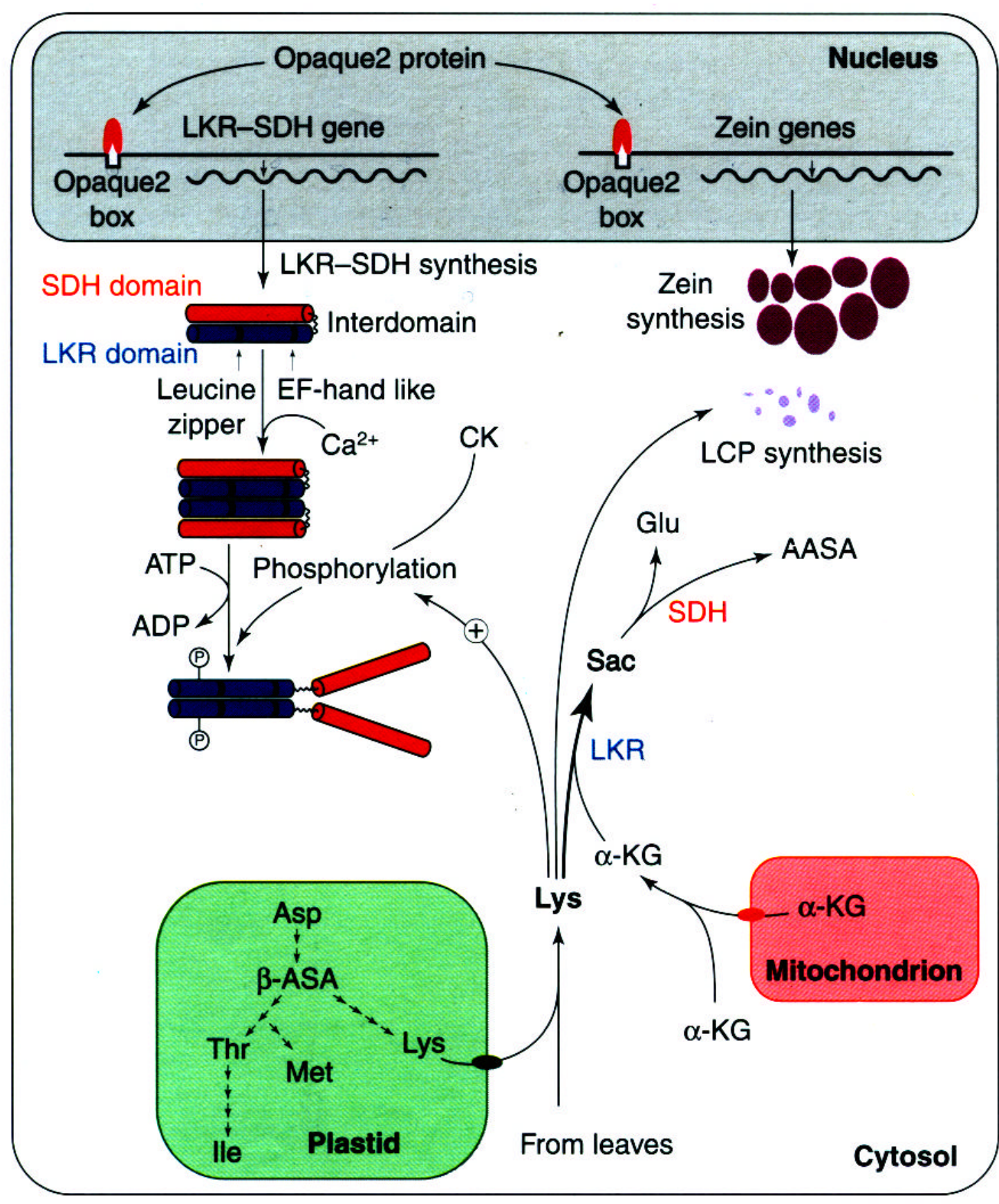

Trends in Plant Science

Figura 3 - Regulação pós-traducional da enzima bifuncional LOR-SDH. Papel regulatório do $\mathrm{Ca}^{+2}$ e da fosforilação (promovida por Caseína Quinase-CK) provávelmente dependente dos níveis de lisina no citosol. LCP- proteínas que incorporam lisina. (Arruda et al., 2000). 
Embora plantas mutantes tenham contribuído para o entendimento dos processos que regulam a síntese de lisina e treonina, tais mutantes apresentam diversas limitações devido aos procedimentos de seleção pelo quais eles são obtidos. Como conseqüência da sensibilidade de AK e DHDPS a retroinibição pela síntese de lisina e treonina, mutantes isolados resistentes a LT ou AEC possuem enzimas alteradas estruturalmente, mas não enzimas com expressão ou compartimentalização alteradas (Galili et al., 1995). Ditas limitações foram salvas pela expressão de genes bacterianos codificando enzimas AK e DHDPS em plantas transgênicas (Perl et al., 1992; Shaul \& Galili, 1992a e b; Falco et al., 1995; Kwon et al., 1995; Brinch-Pedersen et al., 1996; Tzchori et al., 1996).

Para obter plantas transgênicas, a seqüências dos genes bacterianos codificando para a AK e DHDPS foram ligados ao promotor constitutivo 35S do vírus do mosaico da couve-flor. Alguns transgenes, incluem o DNA codificando um peptídio trânsito plastidial, para dirigir a enzima bacteriana para a organela.

Um análise global, permite afirmar que a expressão da AK bacteriana resultou num aumento considerável da produção de treonina solúvel, Entretanto, a expressão de DHDPS bacteriana causou aumento na produção de lisina solúvel (Perl et al., 1992; Shaul \& Galili, 1992a, b).

Shaul \& Galilli (1992b), transformaram plantas de tabaco utilizando o gene mutante $l y s C$ de $E$. coli que codifica uma forma de $\mathrm{AK}$ insensível a lisina. Foi verificado um aumentos de 2 a 9 vezes na quantidade de treonina solúvel nas folhas. $\mathrm{Na}$ concentração de lisina e isoleucina o aumento foi de 20 e 5,5 vezes, respectivamente, quando plantas foram cultivadas em casa de vegetação. Estas plantas apresentaram porém, alterações como diminuição da área foliar, esterilidade parcial e atraso no florescimento.

Plantas transgênicas de tabaco contendo o promotor ak-hsdh de Arabidopsis thaliana, fusionado ao gene repórter GUS, mostraram regulação temporal e espacial específica para tecidos vegetativos, flores e sementes durante o desenvolvimento (ZhuShimoni et al., 1997). O padrão GUS de pigment ação foi correlacionado com o padrão 
de hibridação in situ de uma sonda anti-sense de AK-HSDH. Folhas jovens apresentaram elevada pigmentação GUS, enquanto que folhas maduras foram GUS negativas. $\mathrm{O}$ transgene AK-HSDH-GUS foi evidente em meristema apical e hteral, em brotos laterais, em folhas jovens desenvolvidas a partir de meristema e em tecido cortical e vascular do caule jovem (Zhu-Shimoni et al., 1997). Nas flores, pétalas foram GUS positivas, anteras particularmente no tapetum e em grãos imaturos de pólen e na ginoécia a atividade GUS foi observada no estigma, estilo e ovário (Zhu-Shimoni et al., 1997).

Shaul \& Galilli (1992a), transformaram plantas de tabaco com o gene dapA que codifica para a enzima DHDPS de E. coli. O transgene continha as seqüências promotora $35 \mathrm{~S}$ e peptídio sinal para o cloroplasto. As plantas transgênicas apresentaram níveis elevados de lisina nas folhas, quando comparadas com as plantas normais.

Falco et al. (1995), transformaram plantas de canola com o gene dapA de Corynebacterium, fusionado ao promotor de faseolina e o peptídio trânsito da subunidade menor da ribulose 1,5-bifosfato carboxilase. A expressão do gene bacteriano incrementou a acumulação de lisina, aproximadamente 100 vezes nas sementes de canola. Isto representou, níveis de lisina de $12 \%$ do total de aminoácidos na semente, dobrando o conteúdo do aminoácido nas sementes normais. A acumulação de lisina nas sementes apresentou correlação positiva com o número de cópias do transgene. No entanto, houve aumento nos níveis de ácido $\alpha$-aminoadípico, indicando que quantidades consideráveis de lisina estariam sendo degradadas e portanto, a quebra do ácido $\alpha$ aminoadípico seria o passo que limita a velocidade de catabolismo de lisina em canola.

Plantas de canola transformadas com o gene lysC-M4 (codifica para AKIIIinsensível a lisina) de E. coli, junto ao promotor de faseolina (Falco et al., 1995), apresentaram aumentos no nível de treonina, como observados pelos autores também em sementes de tabaco. Isto sugere que a concentração de lisina intracelular controla o fluxo downstream na via do aspartato.

Em plantas de canola transformadas com ambos dapA e lysC-M4 (Falco et al., 1995), não houve aumento na acumulação de lisina nas sementes e a presença de DHDPS bacteriana não permitiu a acumulação em excesso de treonina. Aparentemente, 
a DHDPS de Corynebacterium direcciona o fluxo de vias intermediárias downstream do ramo da lisina e além do ramo da treonina.

Sementes de soja transgênicas, contendo os genes dapA e lys $C-M 4$, com altos níveis de lisina (10 a 100 vezes), foram obtidos por Falco et al. (1995). A lisina, representou um aumento de 5-vezes do total de aminoácidos com relação ao genótipo normal, mas diferente de canola, não houve correlação com o número de cópias do transgene. No entanto, foi observado aumento nos níveis de sacaropina, diferentemente do observado em canola. Portanto, o aumento deste intermediário indica que a quebra da sacaropina é o passo que limita a velocidade no catabolismo de lisina.

Brinch-Pedersen et al. (1996), analisaram plantas transformadas de cevada que expressavam constitutivamente os genes de E. coli, dapA e LysC que codifica para AK. Folhas de transformantes primários exibiram incrementos de lisina e metionina de aproximadamente 14 e 8 vezes, respectivamente. A atividade de AK e DHDPS incrementaram em 2 e 9 vezes, respectivamente, quando comparadas com plantas normais. Os autores, também observaram em sementes de plantas transgênicas com DHDPS, um aumento de lisina, arginina e asparragina solúveis em 2 vezes, e uma redução de $50 \%$ de prolina solúvel. Para sementes transformadas com AK bacteriana, não houve mudanças nos níveis de aminoácidos em relação as plantas não transformadas. A progênie $T_{1}$ apresentou níveis similares de atividade enzimática, 2.3 vezes para $\mathrm{AK}$ e 4.0 a 9.5 vezes para DHDPS. As sementes $\mathrm{T}_{1}$ apresentaram níveis similares de aminoácidos aos observados em sementes $\mathrm{T}_{0}$.

Tzchori et al. (1996), transformaram plantas de Arabidopsis thaliana ecotipos C24 e Columbia, com os genes quiméricos bacterianos que codificam para as enzimas DHDPS e AK. Estas construções incluíam o promotor 35S do CaMV e o peptídio trânsito plastidial do gene $r b c S-3 A$ de ervilha. Plantas transgênicas expressaram atividade DHDPS elevada $(50 \mathrm{~mol} \%)$ e produziram níveis elevados de lisina com diminuição considerável de treonina em comparação com as plantas não transformadas. No entanto, os níveis de lisina foram muito variáveis dentro e entre genótipos transgênicos e não houve correlação direta entre os níveis de lisina e a atividade de DHDPS. Plantas transgênicas apresentaram fenótipos anormais durante os estágios 
primários do desenvolvimento, emitindo brotos normais e produzindo semente nos estágios avançados. A análise das plantas transformadas com o gene da AK de E. coli, evidencio incremento em 9 vezes na atividade AK, embora não provoco incremento substancial nos níveis de treonina solúveis ou outros aminoácidos em relação a plantas normais. Isto sugere um modo de controle mais relaxado da atividade AK em Arabidopsis não provocado por simples perda de sensibilidade de AK endógenas para retroinibição por lisina e treonina, porque plantas selvagem cresceram, mas transgênicos foram inibidos, em meio suplementado com estes aminoácidos.

Zhu-Shimoni et al. (1997), determinaram a atividade do promotor AK-HSDH de A. thaliana fusionado ao gene repórter GUS durante o desenvolvimento das sementes de tabaco transgênico. Observaram que durante os estágios primários do desenvolvimento da semente (8 a 10 dias após a antesis - DAA), exibiram elevada pigmentação GUS. Com o termino da embriogênese (10 a 13 DAA), baixos níveis de expressão GUS foram evidentes no estágio de coração do embrião, como também no endosperma. Durante o estágio intermédio da maduração da semente (13-20 DAA) GUS permaneceu relativamente baixo no endosperma e foi concentrado próximo ao funículo, região de ingresso do nitrogênio importado para a semente em desenvolvimento. No entanto, no estágio de torpedo do embrião (18 a 20 DAA) a expressão do gene AK-HSDH-GUS foi significante. Durante esta etapa do desenvolvimento da semente, tem inicio a síntese de proteínas de reserva (Karchi et al., 1995), e a expressão GUS foi primeiro detectada no hipocótilo do embrião e mais tarde cobriu todo o embrião. Durante a maturação e dessecação da semente, a expressão de GUS diminuiu no embrião, sendo somente GUS positivo o ápice radicular e tecidos vasculares. Notavelmente, o endosperma apresentou elevada pigmentação GUS. Os autores, indicaram uma correlação entre os níveis elevados de lisina e treonina solúvel durante o estágio de 14-22 DAA de desenvolvimento da semente com a expressão de GUS no embrião. A comparação do padrão de expressão do transgene, AK-HSDH-GUS, foi muito similar a expressão do gene AK-HSDH endógeno de tabaco como determinado por hibridização in situ (ZhuShimoni et al., 1997), sugerindo que a expressão do gene AK-HSDH é altamente regulada a nível transcricional. Finalmente, durante a germinação de plântulas de tabaco 
transgênico, a expressão do transgene AK-HSDH-GUS em condições de escuridão foi localizada no hipocótilo e a posterior exposição a luz revelou pigmentação azul no endosperma (Zhu-Shimoni et al., 1997). Isto indicaria que a atividade do promotor do gene AK-HSDH durante a germinação é regulada pela luz.

Vauterin et al. (1999), clonaram e sequiênciaram um fragmento de DNA de 900 bases localizado upstream da região que codifica para o gene dhdps de A. thaliana. Posterior fusão com o gene repórter GUS, permitiu estudar as propriedades de transcrição deste promotor ( $\mathrm{p} d h d p s)$. A expressão de pdhdps em plantas transformadas de Arabidopsis e Nicotiana tabacum foi observada ter especificidade do tipo celular. Nas partes vegetativas das plantas de Arabidopsis, a atividade de GUS foi localizada nos meristemas e tecidos vasculares de raízes jovens, nos vasos de caule e folhas e nos meristemas de raízes jovens. Nas flores, elevada expressão foi observada nos carpelos, estilo, estigma, embriões em desenvolvimento, tapetum de anteras jovens e pólen. O fragmento $\mathrm{p} d h d p s$ foi observado a dirigir sua própria expressão tecido-específica em $N$. tabacum. A preferência celular da expressão do gene dhdps se correlaciona com os tecidos de rápido crescimento (meristemas, sementes e pólen em desenvolvimento) onde a síntese de proteína é elevada, e síntese in situ é necessária para o metabolismo da lisina. A relação entre a transcrição do gene dhdps e a necessidade de lisina em tecidos específicos indica que a expressão da enzima é regulada ao nível do RNA. Embora a baixa concentração de lisina deveria estimular a sua síntese, mediante uma inibição leve da enzima DHDPS, é observado ativação transcricional do gene dhdps em tecidos ativos onde o metabolismo (turnover) de lisina é elevado. Isto sugere que a regulação transcricional do gene dhdps exerce um controle primário na síntese de lisina a instâncias da retroinibição pelo produto final sobre DHDPS. O controle, por retroinibição da enzima DHDPS pela lisina solúvel, deveria ser uma regulação secundaria restrita ao nível celular com o objetivo de prevenir a acumulação de lisina nas organelas, um forte aminoácido básico, para níveis tóxicos.

Em plantas a lisina regula sua própria síntese por retroinibição da DHDPS. Em sementes de tabaco o acúmulo de lisina solúvel estimula a atividade da LOR, no entanto muito pouco é conhecido sobre outros mecanismos regulatórios, tais como a repressão 
de genes ou mecanismos de transdução de sinal intracelular, que estariam envolvidos na síntese ou degradação da lisina.

Karchi et al. (1995), analisaram a atividade da LOR em sementes imaturas de $N$. tabacum cv Samsum e seus derivados transgênicos AE26 (high-lysine), que expressam uma DHDPS bacteriana. Nas sementes selvagens, o nível basal de atividade da LOR foi aumentado pela injeção de lisina exógena, e nas transgênicas a atividade foi estimulada pela alta produção de lisina endógena. Em ambos, a atividade LOR foi reduzida significativamente quando tratadas com EGTA, mas restaurada quando adicionado $\mathrm{Ca}^{+2}$. Nos genótipos selvagens a atividade LOR foi fortemente estimulada quando tratada com ionomicina ou ácido okadaico (inibidor de proteínas fosfatase). Entretanto, transgênicos na presencia de K-252 (inibidor de proteínas quinases) sofreram redução de sua atividade. Claramente a atividade da LOR estimulada por lisina opera através de uma cascata de sinalização intracelular envolvendo $\mathrm{Ca}^{+2}$ e fosforilação de proteínas.

$\underline{\text { Genes, mRNAs e proteínas envolvidas no metabolismo da lisina }}$

Ghislain et al. (1994), isolaram o gene de A. thaliana que codifica para a AK (ATP: $L$-aspartato 4-fosfotransferase) a partir de uma livraria de DNA genômico, usando o gene $a k-h s d h$ de cenoura como sonda hibridizante. O cDNA correspondente foi isolado de uma livraria de cDNA realizada a partir de mRNA poly $(\mathrm{A})^{+}$, extraídos de culturas de células em suspensão. A comparação de seqüências entre o produto do gene de Arabidopsis e a enzima AK-HSDH de cenoura e os gene thrA e metL de E. coli, mostrou $80 \%, 37.5 \%$ e $31.4 \%$ de identidade, respectivamente. A região codificando a apoproteína é interrompida por 15 íntrons, predominantemente da classe rica em pirimidinas. Uma seqüência para direcionamento ao cloroplasto, contendo dois íntrons, foi identificada upstream da região codificante e apresentou baixa identidade de sequiência com o peptídeo trânsito de cenoura. A presença desta seqüência explicaria a 
localização no cloroplasto da enzima. Análise da seqüência 5 ' revelou a presença de elementos promotores conservados, como a seqüência de união a $O 2$ e a sequiência similar de reconhecimento por GCN4 de levedura. A proteína AK-HSDH apresentou uma longitude de 824 aminoácidos correspondente com um $M_{r} 90065$ Da. A análise da sequiência de aminoácidos revelou regiões altamente conservadas: o motivo KFGG, presente imediatamente no inicio do polipeptídeo, a seqüência DPR altamente conservada entre todas as AKs e que determina a atividade quinase da enzima e o motivo G-X-G-X-X-G de união a NADPH no domínio HSDH. Portanto, o gene $a k-h s d h$ de Arabidopsis, como já descrito em cenoura (Weisemann \& Matthews, 1993), esta estruturado em 4 domínios estando na região 5' o peptídeo trânsito e o domínio AK; uma região interdomínio; e na região 3' o domínio HSDH.

Dante et al. (1999), clonaram e caraterizaram o gene DapA que codifica para DHDPS, a partir de plântulas de Coix lacryma-jobi cv Adlay, mediante o uso de um clone de cDNA DHDPS de milho. O gene DapA, foi observado estar presente em cópia simples e estruturado em três éxons interrompidos por dois íntrons. Detalhes da estrutura na região $5^{\prime}$, revelaram um putativo sítio cap, as seqüência TATA e TGACTC de união para GCN4, upstream ao sítio de início da transdução, respectivamente. A seqüência de aminoácidos revelou um polipeptídeo de 377 aminoácidos que incluía a seqüência $\mathrm{N}$ terminal do peptídio trânsito cloroplastidial. A proteína madura apresentou 326 resíduos com um $M_{r} 35993$ Da. A comparação de seqüências de aminoácidos da proteína DHDPS de Coix revelou $95 \%$ de identidade com a proteína de milho, $89 \%$ com a de trigo e $75 \%$ com as proteínas de plantas dicotiledôneas. Análise da expressão do gene DapA mostrou aumento nos níveis de mRNA DHDPS em coleoptiles, embriões imaturos e endospermas. Plântulas crescidas na escuridão apresentaram níveis diminuídos de mRNA. O padrão observado foi similar ao acúmulo de mRNA DHDPS em milho. O acúmulo de mRNA DHDPS durante o desenvolvimento do embrião e do endosperma, em Coix e milho, foram altos nas etapas iniciais e diminuíam com o processo da maturação da semente. Em ambas espécies, usualmente embriões exibiram quantidades maiores de transcritos do que endospermas. No entanto, os níveis de mRNA DHDPS em 
endosperma de Coix decresceram abruptamente após 10 DAP. Em milho os níveis dos transcritos permaneceram constantes durante todo o desenvolvimento.

Dante et al. (1999), estudaram também a expressão do gene DapA no mutante o2 de milho F-352, e observaram que não foi afetado durante o desenvolvimento global da semente apresentando um leve decréscimo nos níveis de mRNA DHDPS, tanto no endosperma como no embrião de grãos do mutante e milho normal. Estudo a nível molecular, mediante ensaios de união seletiva mostrou que não houve união entre a sequiência de união do GCN4 no gene dhdps de Coix e a proteína O2 ( $\beta$-Gal::O2) de milho na região de 192 pb upstream do sítio de inicio da tradução.

Clones e cDNAs codificando a enzima bifuncional LOR-SDH foram isoladas a partir de Arabidopsis (Tang et al., 1997; Epelbaum et al., 1997) e milho (Kemper et al., 1999).

Tang et al. (1997), identificaram e caraterizaram um cDNA de Arabidopsis que codifica para uma enzima SDH monofuncional (designado cAt-SDH) e um cDNA LORSDH (designado cAt-LOR-SDH). O primeiro contém um marco de leitura que codifica uma putativa proteína de 482 aminoácidos. A seqüência codificante de cAt-SDH apresentou homologia significante com SDH (LYS9) de levedura, mostrando $36.1 \%$ de identidade e $56.4 \%$ de similaridade. O cAt-LOR-SDH contém uma região codificante de 3195 nucelotídeos que codificam para uma proteína de $117 \mathrm{kDa}$. O tamanho da proteína codificada é similar ao tamanho da LOR-SDH recentemente purificada de milho (125 kDa; Gonçalves-Butruille et al., 1996) e de soja (123 kDa; Miron et al., 2000). A região N-terminal correspondente a putativa proteína codificada por cAt-LORSDH (460 aminoácidos), exibiu homologia com a LOR monofuncional de levedura, com $24.9 \%$ de identidade e $52.1 \%$ de similaridade. Alinhamento de seqüências de aminoácidos entre, o polipeptídeo produto de cAt-LOR-SDH e os polipeptídeos monofuncionais de levedura, LOR e SDH, mostraram que a proteína derivada de cAtLOR-SDH continha uma região intermediária (aminoácidos 465-582) que estava ausente nas enzimas LOR e SDH de levedura (Tang et al., 1997). Isto indica a presença de uma região interdomínios, tal como foi também observados para outros polipeptídeos 
bifuncionais, como AK-HSDH (Ghislain et al., 1994; Galili, 1995). Finalmente, demonstraram que cAt-SDH e cAt-LOR-SDH são codificados por um simples gene.

Kemper et al. (1999), mediante o uso de primers degenerados e RT-PCR., isolaram um clone de cDNA (ZLORSDH) que codifica para a enzima bifuncional LORSDH, de endosperma de milho híbrido F-352. O cDNA codifica para um polipeptídeo de 1064 aminoácidos, o que representa uma proteína de $116.8 \mathrm{kDa}$, similar ao polipeptídeo de $125 \mathrm{kDa}$ purificados por Gonçalves-Butruille et al. (1996). Os autores, observaram banda simples quando hibridizado RT-PCR DNA ZLORSDH com DNA genômico de milho, sorgo e Coix, sugerindo a presença de um gene em copia simples na família Andropogoneae sp. Análise de seqüências de aminoácidos do polipeptídeo LOR-SDH, mostrou $42 \%$ de similaridade do domínio C-terminal de SDH com a proteína LYS9 e o domínio N-terminal $27 \%$ de similaridade com a proteína LYS1, que constituem a proteína SDH e LOR de levedura, respectivamente. Com Caenorhabditis elegans apresenta similaridade de $46 \%$, com rato de $44 \%$ e com Arabidopsis $72 \%$. Interessantemente, a região interdomínio é $57 \%$ idêntica com Arabidopsis, entretanto esta região parece estar ausente nas proteínas LOR-SDH de C. elegans e rato.

Os genes codificando LOR-SDH em Arabidopsis e milho são grandes e complexos, sendo que o gene de milho contém 26 éxons e o gene de Arabidopsis tem 25 éxons (Epelbaum et al., 1997). Exceto para o segundo éxon do gene de milho, o qual esta ausente em Arabidopsis, os éxons estão altamente conservados em tamanho e sequiência. No entanto, os íntrons são divergentes entre as duas espécies, sendo maiores no milho (Figura 4). Claramente as enzimas LOR-SDH de Arabidopsis e milho têm uma região interdomínio de aproximadamente 100 resíduos de comprimento. A análise de seqüência dos genes lor-sdh de milho e Arabidopsis contém seqüências TATA e CCAAT no contexto do promotor e também na região interna (Figura 4). Isto permitiria um promotor para a produção de transcritos codificando o polipeptídeo bifuncional e o outro para a produção de transcritos SDH monofuncionais. Ainda, sequiências similares de união a proteína GCN4, envolvidas na ativação transcricional de genes participando do metabolismo de nitrogênio em plantas e leveduras, podem ser encontradas em promotores localizados upstream e internamente no gene de milho, e somente no 
promotor interno do gene de Arabidopsis. No entanto, sítios de união para O2, similares ao observados nos promotores de genes de prolamina, estão também presentes nos promotores upstream e interno do gene lor-sdh de Arabidopsis, mas somente presente no promotor upstream do gene lor-sdh de milho. Possivelmente, ambas seqüências: $O 2$ e GCN4, estão envolvidas na regulação transcricional dos genes lor-sdh de milho e Arabidopsis, e portanto, a ausência de uma seqüência $O 2$ no promotor interno de milho deveria explicar porque esta espécie expressa somente o polipeptídeo bifuncional, entretanto Arabidopsis expressa a enzima LOR-SDH e a enzima SDH monofuncional a partir do mesmo gene (Arruda et al., 2000).

De grande interesse, resulta a presença destas duas seqüências na região promotora dos genes que codificam para $a k-h s d h$ de cenoura (Weisemann \& Matthews, 1993) e Arabidopsis (Ghislain et al., 1994), e DHDPS de Coix lacryma jobi ( Dante et al., 1999).

Analises funcionais de transgenes, contendo um promotor de AK-HSDH de $A$. thaliana truncado downstream a seqüência GCN4, e fusionado ao gene GUS, apresentaram atividade diminuída em plantas de tabaco transgênico (Zhu-Shimoni et al., 1997). Embora, anteriormente tenha sido observado que a regulação transcricional mediada pela proteína $\mathrm{O} 2$ em vários genes codificando proteínas de endosperma envolve a união da proteína GCN4 a suas sequiências promotoras (Lhomer et al., 1991; Maddaloni et al., 1996; Yunes et al., 1998); no gene de dhdps de Coix, a pesar de conter referida sequiência na região 5' do sitio de inicio da transdução, parece que sesta não está sendo regulada diretamente por $\mathrm{O} 2$, como observado pela diminuição menos severa de mRNA DHDPS no embrião e endosperma de milho o2. Estudos a nível molecular (Dante et al., 1999), mediante ensaios in vitro de união seletiva, demonstraram que não houve união entre a sequiência GCN4 do gene dhdps de Coix e a proteína O2 (produto do transgene $\beta$-Gal::O2) de milho, upstream do sítio de inicio da tradução. Em trabalhos anteriores no entanto, a proteína quimérica $\beta-\mathrm{Gal}:: \mathrm{O} 2$ foi observada unir-se ao promotor do gene que codifica para a $\alpha$-coixina de $22 \mathrm{kDa}$, onde $\mathrm{O} 2$ uniu-se a seqüência GCN4 (Yunes et al., 1998). 


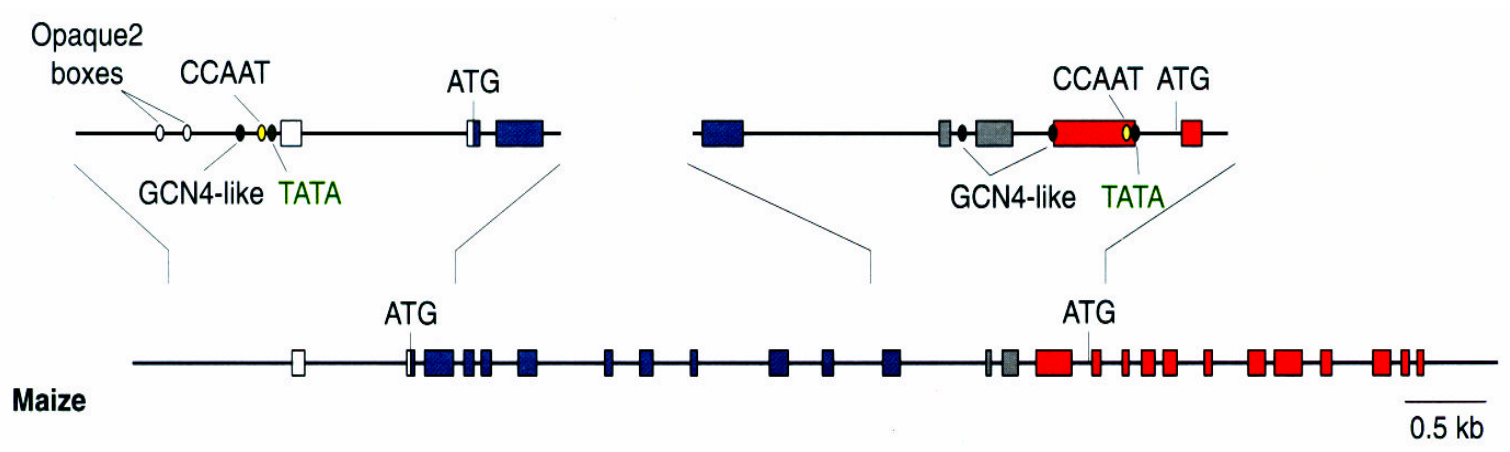

Arabidopsis

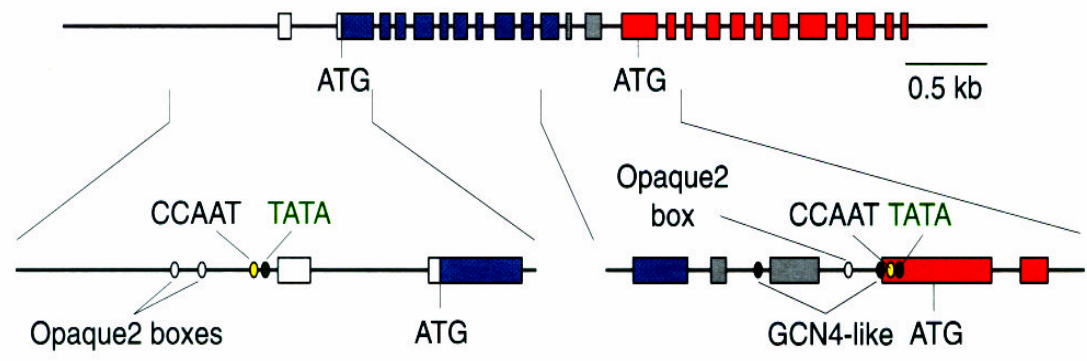

Trends in Plant Science

Figura 4 - Estrutura dos genes lor-sdh de milho e Arabidopsis. (Arruda et al., 2000).

Estes elementos regulatórios, são muito similares ao GCN4 existentes na maioria dos genes de levedura codificando para enzimas envolvidas na biossíntese de aminoácidos e regulando a expressão das enzimas em resposta as necessidades de aminoácidos (Hinnebusch, 1988).

Estudos de expressão transitória para o promotor C-hordeína (Muller \& Kundsen, 1993), sugerem que o GCN4 box poderia regular a expressão do gene da hordeina (proteína de reserva de sementes de cevada), em resposta ao nitrogênio. Grant \& Bevan (1994), sugerem que o $\mathrm{NH}_{3}$, produzido pela desaminação de asparragina (processo catalisado pela asparaginase) originando aspartato, poderia ser o sinal que induz a expressão dos genes das proteínas de reserva. Usando o gene quimérico para o promotor da lupina asparraginase fusionado ao gene GUS, os autores observaram que o promotor foi principalmente expresso nas células do endosperma de semente de tabaco transgênicas e a expressão máxima foi alcançada dias prévios ao início da expressão dos 
genes que codificam para as proteínas de reserva. Este período é também caraterizado

pela conversão rápida de asparragina em aspartato (Karchi et al., 1993). É possível que a indução dos genes codificando para as proteínas de reserva da semente bem como os genes que codificam para as enzimas envolvidas na síntese de aminoácidos, sejam regulados pelo $\mathrm{NH}_{3}$.

\section{Atividade do fator transcricional Opaco2}

No milho, o polipeptídeo Opaco2 (O2) pertence a família de fatores de transcrição b-ZIP (basic-leucine zipper) e atua regulando a expressão de certos membros da família de genes que codificam para as proteínas de reserva zeínas (prolaminas) na semente.

A mutação $o 2$ resulta na redução da expressão destes genes, sendo a classe zeína $22 \mathrm{kDa}$ a mais severamente afetada (Muller et al., 1995) e em menor extensão a zeína de $15 \mathrm{kDa}$. Consistente com estes efeitos fenotípicos, somente os genes das zeínas de 22- e 15 kDa contém sítios de união para O2 nos promotores (Schmidt et al., 1992; Cord-Neto et al., 1995; Vicente-Carbajosa et al., 1997). Lohmer et al. (1991), informaram a união de $\mathrm{O} 2$ a sequiências específicas na região promotora dos gene $b-32$.

A proteína O2 reconhece uma sequiência palindrômica imperfeita 5'TCCACGTAGA-3', denominada caixa Opaco2 (O2 box), presente nos promotores de genes zeínas $22 \mathrm{kDa}$. Na região promotora destes genes encontra-se a caixa prolamina (prolamin box) e dentro dela foram observados três sítios de união para $\mathrm{O} 2$, denominados Z1, Z2 e Z3, em associação com o motivo endosperma (endosperm motif). Próximo ao extremo 3' da caixa prolamina foi observada uma seqüência com similaridade a seqüência de união do fator GCN4 (Mauri et al., 1993; Muller et al., 1995). 
Um segundo tipo de fator de transcrição b-ZIP em milho, chamado OHP1 (O2heterodimerizing protein 1), foi também observado a unir-se a caixa Opaco2, tanto na forma de um homodímero como em complexo heterodímerico associado a $\mathrm{O} 2$ (Pysh et al., 1999).

A proteína PBF (prolamin box-binding factor), que pertence a classe de proteínas $\mathrm{Cys}_{2}$-Cys 2 zinc-finger em plantas, foi recentemente observada como capaz de unir-se especificamente aos promotores da família de genes zeína $22 \mathrm{kDa}$ e in vitro a interagir com O2. Este fator trans específico do endosperma, se une com uma elevada afinidade ao motivo endosperma, uma seqüência de 7-pb altamente conservada (5'-TGTAAAG3'), observada nos promotores dos genes para proteínas de reserva na semente da maioria dos cereais (Vicente-Carbajosa et al., 1997).

Mauri et al. (1993), demonstraram que O2 pode substituir a proteína GCN4 em células transgênicas de levedura. Foi determinado que a seqüência protegida pela união de $\mathrm{O} 2$ é também o sítio de união do fator transcricional GCN4.

A síntese de polipeptídeos zeínas nas células do endosperma se inicia aproximadamente 10 a 12 DAP e alcançam um platô em 35 a 40 DAP. De modo similar, os transcritos $\mathrm{O} 2$ aparecem 11 DAP e permanecem constantes por aproximadamente 25 dias (Gallusci et al., 1994). A participação de várias proteínas na regulação da expressão dos genes zeínas poderia estar sendo controlada por mecanismos que operam póstransducionalmente e em resposta a diferente condições fisiológicas e ambientais (Ciceri et al., 1997).

Ciceri et al. (1997), trabalhando com endosperma de milho, observaram a existência de proteínas $\mathrm{O} 2$ heterogêneas, dois polipeptídeos de 68 e 72 kDa, e nove isoformas com pontos iso-elétricos diferentes em gel com pH fixo entre 4.0 e 5.0. Posteriormente, por técnicas de imunomarcação in vitro e in vivo, demonstraram que $\mathrm{O} 2$ é fosforilado e que as isoformas correspondem a diferentes graus de fosforilação do polipeptídeo. Somente as formas não fosforiladas e hipofosforiladas de $\mathrm{O} 2$ podem-se unir com elevada afinidade as sequiências O2 box. Embora, as isoformas tenham apresentado taxas constantes durante o desenvolvimento do endosperma de milho, houve mudanças durante o dia e a noite, com níveis máximos da forma hiperfosforilada durante 
a noite. Os resultados, demonstram que $\mathrm{O} 2$ se apresentaria formando um pool de polipeptídeos com diferente graus de fosforilação e demonstra que a atividade de união a seqüência $O 2$ box, seria modulada por um mecanismo de fosforilação/desfosforilação que seria influenciado pelas variações nas condições ambientais.

Ciceri et al. (1999), trabalhando com endosperma de milho, mostraram que os transcritos $\mathrm{O} 2$ e PBF compreendem oscilações pronunciadas durante o ciclo dia-noite. Ao meio dia apresentaram os níveis mais elevados dos mensageiros e a meia noite os níveis mais baixos. Por outro lado, o transcrito OHP1 permaneceu constante durante o ciclo dia-noite. Isto demonstra uma correlação entre altos níveis de O2 mRNA com elevada atividade de união ao DNA durante o dia, enquanto a mudança para uma forma inativa da proteína à noite se correlaciona com aredução nos níveis do mensageiro $\mathrm{O} 2$. Por outro lado, foi observado que a semente não está diretamente envolvida na percepção da luz, mas responderia a fluxos de nutrientes durante o dia para o endosperma. Ainda, os autores observaram que a proteína $\mathrm{O} 2$ não regula sua própria transcrição. Assim, é proposto que as variações dos transcritos $\mathrm{O} 2$ bem como o padrão de fosforilação de $\mathrm{O} 2$ estariam controlados por um ritmo circadiano. $\mathrm{O}$ mensageiro PBF apresentou um comportamento paralelo a $\mathrm{O} 2$ entanto que OHP1 permane ceu inalterável. Desta forma, a atividade de $\mathrm{O} 2$ seria diminuída a noite pela redução dos transcritos $\mathrm{O} 2$, como também pela hiperfosforilação de proteínas $\mathrm{O} 2$ residuais, sugerindo que a atividade de $\mathrm{O} 2$ regulando genes durante o desenvolvimento do endosperma poderia ser sensível a sinais luminosos que seriam captados em outras partes da planta e então transmitidos as sementes em desenvolvimento.

Análises da seqüência de aminoácidos de alelos selvagens para $\mathrm{O} 2$ revelaram a presença de sequiências alvo para três quinases de serina-treonina: proteína quinase $\mathrm{C}$, proteína quinase A e caseína quinase II (CKII). A adição dos grupos fosfatos ao polipeptídeo O2, foi proposta a ser realizada pela proteína CKII (Ciceri et al., 1997) devido a sua localização citoplasmática e nuclear em plantas (Zhang et al., 1993), sua presença em endosperma de milho (Grasser et al., 1989), e sua participação na modulação da atividade dos fatores de transcrição em plantas (Klimczak et al., 1995). Na proteína O2, a seqüência consenso para CKII (Krebs et al., 1988) foi observada em 
oitos locais, seis dos quais poderiam ter relevância biológica por estar enquadrados no domínio de transactivação N-terminal e próximos ao sinal de localização nuclear (NLSB) (Ciceri et al., 1997).

A albumina citosólica de endosperma de milho, chamada b-32, foi observada ser controlada pelo locus o2 (Mertz et al., 1964). Níveis de b-32 e zeínas 22 kDa, aparecem grandemente diminuídos nos mutantes $o 2$, mas foi demonstrado por experimentos de expressão transitória (Lohmer et al., 1991) que o promotor b-32 pode ser especificamente ativado pela proteína normal O2.

Bass et al. (1992), determinaram que a proteína b-32 é um membro de uma classe grande e amplamente distribuídas de proteínas tóxicas de plantas que inativam ribossomos (RIPs). As RIPs são RNA N-glicosidases que removem uma simples base de um loop conservado no $28 \mathrm{~S}$ rRNA requerido para a união do fator de elongação $1 \alpha$. Ensaios in vitro mostraram que os ribossomos de milho e trigo foram resistentes a b-32 de milho, mas foram inibidos pela RIP gelonina de dicotiledôneas. Os autores observaram também atividade de RIP em sementes em desenvolvimento, semente seca e durante a germinação, sendo que neste último estágio os níveis de atividade de RIP aumentavam, embora a quantidade de proteína b-32 permanecia constante. Não é bem conhecido a função biológica das RIPs, mas elas apresentam caraterísticas de agentes de defesa constitutivos, sendo preferencialmente tóxicos para a célula não vegetal, acumulam em níveis elevados na semente e não tem efeito aparente sobre processos endógenos. Foi sugerido um papel para b-32 na defesa contra patógenos como conseqüência da alta susceptibilidade ao ataque de fungos (Loesch et al., 1975) e de insetos (Gupta et al., 1970), nos grão de milho mutante o2. Bass et al. (1992), sugerem que síntese coordenada, controlada por O2 das RIPs e das proteínas zeínas no milho suprem as plântulas em crescimento de nutrientes e dão proteção contra a invasão de patógenos ao endosperma.

Gallusci et al. (1996), mostraram que o fator de transcrição O2 regula a expressão da enzima citosólica ortofosfato diquinase (cyPPDK) no endosperma de milho. Gallusci et al. (1996) observaram que o padrão de expressão do gene para enzima cyPPDK foi observado a ser similar ao observado para o gene lor-sdh. A cyPPDK esta 
localizada nas células da subaleurona, com sinal menos intenso nas células do endosperma central. A região do endosperma, onde LOR-SDH e cyPPDK estão localizados, é também a região de expressão ativa de genes para zeínas e da proteína O2 (Varagona et al., 1991; Dolfini et al., 1992). Esta observação se correlaciona com a hipótese de controle transcricional de lor-sdh pelo fator $\mathrm{O} 2$ e reforça a idéia de um controle geral do metabolismo de aminoácidos e síntese de proteínas pelo O2. Maddaloni et al. (1996), mediante experimentos de expressão transitória em protoplastos de células do mesófilo de tabaco, demonstraram que a proteína $\mathrm{O} 2$ pode ativar a expressão do gene repórter cloranfenicol acetil transferase sob o controle do promotor cyPPDK1 e por análise de DNaseI-footprint, foi identificado o sítio de união de $\mathrm{O} 2$ no promotor $c y P P D K 1$, que mostrou ser altamente homóloga com os sítios de união de $\mathrm{O} 2$ para o gene $b 32$ (Lhomer et al., 1991).

Em vista da informação armazenada, parece possível sugerir que $\mathrm{O} 2$ atuaria de modo de coordenar a expressão, não somente de certos genes $\alpha$-zeína, e genes como b32 e $b 70$, este último implicado na deposição ordenadas de zeínas nos corpúsculos protéicos (Morocco et al., 1991); mas também genes envolvidos na distribuição do carbono entre proteínas e amido. A forma citosólica da enzima PPDK, foi sugerido a atuar como fornecedor de fosfoenolpiruvato (PEP) para interconversão em aminoácidos durante o desenvolvimento da semente, de modo de manter a síntese de proteínas de reservas. O PEP é o composto chave na interface entre o metabolismo do carbono e nitrogênio, sendo o primeiro composto comum nas vias de síntese dos aminoácidos aromáticos. Além disso, o PEP pode ser usado pela PEP-carboxilase para recapturar $\mathrm{CO} 2$ durante o processo da respiração, gerando então oxalacetato, que em princípio pode ser transaminado para formar aspartato. 


\section{$\underline{\text { Proteínas zeínas }}$}

As proteínas de armazenamento de milho na atualidade são objeto de intensos estudos, por bioquímicos, biologistas moleculares e geneticistas, na tentativa de melhorar a qualidade nutricional do grão. A atenção é devida primariamente a elevada proporção de zeínas no conteúdo total de proteínas e seu baixo conteúdo de certos aminoácidos essenciais como lisina e triptofano.

As proteínas das sementes de milho podem ser classificadas em grupos baseados em suas características de solubilidade, seguindo o protocolo descrito por Osborne (1924) e modificado por Landry \& Moureaux (1970). Deste modo, podem ser fracionadas quatro classes principais de proteínas a partir de grãos de milho: albuminas (solúveis em água), globulinas (solúvel em soluções salinas), prolaminas (solúveis em álcool) e glutelinas (solúveis em álcali diluído).

As albuminas e globulinas representam aproximadamente $6 \%$ das proteínas totais, entretanto glutelinas respondem para 30-45\% do total. As prolaminas, conhecidas tradicionalmente como zeínas, são as mais abundantes e representam $60 \%$ ou mais do total de proteínas (Motto et al., 1996).

A família de proteínas zeínas consistem de uma mistura de polipeptídeos que podem ser identificados por SDS-PAGE, como 28, 22, 20, 16, 14 e $10 \mathrm{kDa}$. Os polipeptídeos foram divididos em classes: $\gamma$-zeínas (28 kDa), $\alpha$-zeínas (22 e 20 kDa), $\beta$ zeínas (16 e 14 kDa) e $\delta$-zeínas (10 kDa) (Motto et al., 1996).

As proteínas de armazenamento das sementes de milho, são sintetizadas nos polirribossomos unidos a membrana, durante o desenvolvimento do endosperma. As zeínas, são translocadas dentro do lume do retículo endoplásmico rugoso (RER) donde são empacotadas em corpúsculos protéicos. No genótipo de milho normal ocorre a deposição ordenada das diferentes classes de zeínas, formando uma estrutura esférica com aproximadamente $1 \mu \mathrm{m}$ de diâmetro que contém uma região central composta predominantemente de $\alpha$-zeínas e em menor proporção $\delta$-zeínas, e uma capa mais periférica de $\beta$ - e $\gamma$ zeínas, cobrindo a região central (Lending \& Larkins, 1992). 
A síntese de zeínas no endosperma de milho, inicia-se aproximadamente 10 DAP, sendo detectáveis as $\alpha$-e $\delta$-zeínas dias antes as $\beta$ - e $\gamma$-zeínas (Motto et al., 1996). A taxa de acúmulo de monas (Brochetto-Braga et al., 1992) e proteínas (Motto et al., 1996) zeínas, alcançam um nível máximo entre 25-28 DAP, após do qual a quantidade de mRNAs diminui gradualmente.

Os genes que codificam para as zeínas foram localizados em clusters ligeiramente ligados nos cromossomos 4, 7 e 10 de milho. Sete genes correspondentes as zeínas de 10 e $20 \mathrm{kDa}$ estão no braço corto do cromossomo 7 e ligados ao locus regulatório O2. Outros nove genes, correspondentes as proteínas de 20 e 22 kDa, localizam-se nos braços, corto e longo, do cromossomo 4, associados ao locus regulador FL2. Um terceiro locus correspondendo a zeína de $22 \mathrm{kDa}$, esta no cromossomo $10 \mathrm{em}$ associação ao locus regulador 07 . Um gene para a proteína de $15 \mathrm{kDa}$ foi observado no cromossomo 7, entretanto o gene para a proteína de $10 \mathrm{kDa}$ foi localizado no braço corto do cromossomo 7 (Motto et al., 1996).

\section{Caraterísticas e propriedades dos mutantes de milho opaco e floury}

Entre as décadas dos '60 e '90 várias mutações nos genes de endospermas foram observadas a alterar a síntese de proteínas de reservas da semente (Mertz et al., 1964), os dois gene mutantes mais importantes para melhorar a qualidade das proteínas de milho são opaco2 (Mertz et al., 1964; Habben et al., 1993) e floury2 (Nelson et al., 1975).

O gene $o 2$ é uma mutação que afeta um loci regulatório do cromossomo 7, que controla a transcrição de gene que codificam para proteínas de reserva nas sementes de milho (Kodrzycki et al., 1989) e é segregado mendelianamente como um simples gene recessivo, entretanto o gene $f l 2$ é semidominante e esta localizado no cromossomo 4 (Nelson et al., 1969; Kodrzycki et al., 1989). 
Embora, o gene $o 2$ altera favoravelmente o espectro de aminoácidos nos grãos de milho, ele representa várias deficiências que limitam seu uso comercial. 1) Geralmente as comparações entre plantas de milho normal e opaco determinam que no referente a produção de grãos, as variedades de milho $o 2$ apresentam uma deficiência na produção de grãos, correlacionado com uma diminuição no peso dos grãos, sendo os mutantes de $10 \%$ a $15 \%$ mais leves que o genótipo normal. 2) Os mutantes apresentam de 1,8 \% a 4,2 \% a mais de umidade relativa nos grãos do que seus tipos normais. Isto implica a necessidade de secado adicional após a colheita. 3) Os grãos mutantes apresentam-se mais farináceos e de tonalidade cinza, com aparência opaca o que contrasta com as sementes brilhantes e transparente das variedade de milho flint ou dent. 4) Em conseqüência, as sementes $o 2$ são mais susceptíveis a infeção por Sitophilus oryzae, com percentagem elevada na perda de peso do grão, Cephalosporium acremonium e Fusarium moniliforme, aumentando o proporção de sementes apodrecidas. 5) Para outras caraterísticas da planta, a informação disponível não sugere qualquer relação significante do gene $o 2$ no referente a mudanças na longitude da espiga, diâmetro da espiga, número de linhas de grão por espiga e número de grãos por linha da espiga. 6) Finalmente as variedades de milho $o 2$ são caraterizadas por apresentar melhor balance de aminoácidos nas sementes, contendo $60 \%$ a $130 \%$ a mais de lisina e triptofano do que nos genótipos normais, porém uma redução de $12 \%$ a $40 \%$ de leucina (Singh \& Asnani, 1975).

É preciso ressaltar que a avaliação das caraterísticas de milho normal e mutante o2, devem ser visadas no contexto do background genético dos materiais e procedimentos usados no desenvolvimento das variedades de milho $o 2$.

Pelas técnicas de microscopia eletrónica, foram observadas diferencias estruturais nos componentes sob-celulares nos endospermas de milhos normal e $o 2$. No milho normal, as estruturas entretecidas constituída de glutelina, rodeiam um número muito grande de corpúsculos protéicos constituídos de zeínas (Wall \& Paulis,1975; Lending \& Larkins, 1992; Motto et al., 1996). Em contraste, os corpúsculos protéicos no endosperma de milho $o 2$, são muito pequenos e sempre cobertos pela grande quantidade de glutelina (Wall \& Paulis, 1975). 
Mertz et al. (1964), mostraram que o milho normal e $o 2$ diferem na qualidade das proteínas no endosperma, sendo uma diminuição na proporção de zeínas com aumento das glutelinas, albuminas e globulinas. $\mathrm{O}$ uso de reagentes redutores permitiram a extração de glutelinas e foi determinado que o2 contém maioritariamente glutelinas e uma pequena proporção de zeínas. Por tanto, o gene $o 2$ favoreceria a produção de mais glutelina a expensas de zeínas, reduzindo também componentes com baixos conteúdo em lisina ou glutelina.

Sodek \& Wilson (1971), trabalhando com a variedade de milho R802, observaram que nos mutantes $o 2$, a fração de proteínas não zeínas aumentou e os níveis de aminoácidos foram maiores do que nos genótipos normal e $f l 2$. Foi determinado que o gene $f l 2$ aumentou a fração de glutelinas, mas teve pouco efeito sobre as zeínas. A composição de aminoácidos do endosperma, revelou que $o 2$ contém maior conteúdo de lisina, histidina, arginina, ácido aspártico e glicina. Entretanto, a proporção de ácido glutâmico, prolina e leucina diminuíram. Na fração de aminoácidos solúveis, o mutante o2 apresentou níveis maiores de ácido glutâmico, glutamina e lisina, mas uma diminuição no conteúdo de prolina. A composição de aminoácidos das glutelinas, nos endosperma normal, $o 2$ e $f l 2$ foram similares na composição global de aminoácidos; no entanto, a linhagem híbrida o2 (R802 x R75) e fl2 (R802), apresentaram uma concentração de aminoácidos de 5,5\%.

Ma \& Nelson (1975), trabalhando com o mutante floury3 de milho, analisaram a composição de aminoácidos dos grãos e observaram aumento nos níveis de lisina em comparados aos do genótipo normal. A mutação $f l 3$ foi assim designada porque a presença de dois alelos $f l 3$ no endosperma determina uma fenótipo que imita aos mutantes $f l 1$ e $f l 2$. Análise de mapeamento genético revelou a localização putativa do gene $f l 3$ no cromossomo 8 de milho.

Misra et al. (1975), analisaram a composição de aminoácidos no genótipo de milho Oh43 e mutantes $o 2$, $f l 2$ e duplo mutante $o 2 / f l 2$. As análise revelaram níveis de lisina maiores nos mutantes quando comparados ao normal. Os níveis de lisina e de triptofano foram o dobro no endosperma $o 2$. Outra mudança caraterística, foi uma diminuição substancial nos níveis de leucina, e muito pouco de alanina, ácido glutâmico 
e prolina, como também no conteúdo total de proteínas. O efeito do gene $f l 2$ mostrou mudanças nos níveis de aminoácidos na mesma direção como os observados em $o 2$, mas não foram tão marcados, embora houve diminuição nos níveis de proteínas do endosperma. O duplo mutante $o 2 / f l 2$ foi similar a $f l 2$ para os níveis de lisina, outros aminoácidos apresentaram níveis similares a $o 2$ ou $f l 2$, ou foram intermédios entre os dois valores. Outras análises, foram realizadas nos mutantes $o 7$ e o2/o7 do milho W22. O padrão de aminoácidos de $o 7$ foi similar ao padrão de aminoácidos do mutante Oh43o2. No entanto, W22o7 apresentou níveis maiores de lisina do que Oh43o2 e uma diminuição acentuada na concentração de proteínas totais. O duplo mutante o2/o7, originado a partir de W23L317o2 x W22o7, não mostrou um efeito aditivo nos níveis de lisina e triptofano. Os resultados destes experimentos, sugerem que os gene $o 7$ e $f l 2$, não produzem um efeito aditivo sobre os níveis de lisina quando combinados com o gene $o 2$. De modo geral, nos genótipos Oh43 e W22 como nos seus mutantes respectivos, houve um aumento na fração de proteínas albuminas, globulinas e glutelinas com diminuição na fração correspondente as zeínas, sendo mais pronunciado no mutante Oh43o2. Os resultados observados na análise de aminoácidos nas frações protéicas do endosperma, revelou que os níveis de lisina foram altos na fração I e V, histidina na fração IV, leucina e alanina na fração II, metionina na fração III e ácido glutâmico e prolina na fração II, III e IV. A lisina e glicina foram baixas na fração II, leucina na fração I, e fenilalanina e tirosina na fração IV. As diferencias observadas nas cinco frações protéicas no endosperma de milho, indicam que o melhoramento na qualidade de proteínas nas variedades mutantes, foram relacionadas com aumentos na fração I e V, e diminuição na fração II. A composição de aminoácidos destas frações foram similares entre genótipos normais e mutantes, sugerindo que as mutações não produziram uma classe nova ou diferente de proteína, mas foram responsáveis pelas mudanças nas proporções das diferentes frações.

Di Fonzo et al. (1980), estudaram e interação entre os genes mutantes $o 2$ e $f l 2$, e também entre $o 2$ e $o 7$ nos endospermas de milho W64A e W22, respectivamente. Os resultados indicaram que na presença de três doses do alelo recessivo $o 2$, a ação de $f l 2$ é complemente eclipsado e somente persiste o fenótipo correspondente a $o 2$ para a 
proporção de zeínas. Uma situação diferente foi observada entre $o 2$ e $o 7$. Estes alelos em condição homozigota reprimem principalmente as zeínas com pesos moleculares elevados e baixos, respectivamente. No duplo mutante $o 2 o 7$, ambos alelos estão ativos e reduzem aditivamente a síntese de zeínas. Assim, $o 2$ é aparentemente epistático sobre $f l 2$ no controle da síntese de zeínas, entretanto junto a 07 pareceriam atuar independentemente.

Habben et al. (1993), observaram no mutante W64Ao2 um conteúdo de 490 mug de lisina comparada com 350 mug no genótipo normal W64A. Mediante análise de SDS-PAGE de proteínas do endosperma indicaram que várias proteínas não zeínas foram mais abundantes no mutante do que no genótipo normal.

Yau et al. (1999), trabalhando com endospermas de milho T224, MO17 e B73 observaram que os mutantes $o 2$ apresentavam níveis elevados de lisina, como também um aumento no conteúdo de albuminas e globulinas e no conteúdo de glutelinas, excetuando a diferencia não significativa entre B73 e B73o2. Os níveis de zeínas foram sempre menores que nos genótipos normais.

Portanto, a mutação $o 2$ causa a supressão específicas da classe xína $22 \mathrm{kDa}$ (Burr \& Burr, 1982), resultando em uma redução global de 50 a $70 \%$ das proteínas zeínas (Mertz et al., 1964). Aparentemente o gene mutante reprimiria a taxa de transcrição, particularmente daqueles genes codificando para a classe zeínas de $22 \mathrm{kDa}$ (Kodrzycki et al., 1989). Outra mutação recessiva, denominada opaco5 foi observada a produzir a redução específica da classe zeína de $20 \mathrm{kDa}$ (Motto et al., 1996).

Plotnikov \& Bakaldina (1996), observaram que nos grão de milho o2 a uma diminuição no conteúdo de mRNAs das zeínas, sendo de $40 \%$ para a classe 19 kDa e 4 \% para a classe $22 \mathrm{kDa}$, comparados com $55 \%$ e $40 \%$, respectivos observados no genótipo normal. Quando espigas de milho $o 2$ foram injetadas in vivo com actinomicina D, $80 \%$ do mRNA zeína $19 \mathrm{kDa}$ foi detectado, entanto que a classe $22 \mathrm{kDa}$ diminui para valores não detectáveis. Seguidamente, experimentos in vitro confirmaram que o mRNA zeína $19 \mathrm{kDa}$ foi mais estável e o mRNA zeína $22 \mathrm{kDa}$ o mais susceptível a degradação. Porém, paralelamente foi determinado um aumento em 60 a $70 \%$ na atividade RNase nos grãos de milho o2. Aparentemente, a estabilidade diferencial dos mRNAs 
representam um fator importante na modulação pós-transcricional da expressão de genes que codificam para zeínas durante o desenvolvimento das sementes de milho.

Outras proteínas são também afetadas pela mutação $o 2$, por exemplo, a atividade ribonuclease é 2 a 6 vezes maior em endosperma mutante. O endosperma $o 2$, carece de uma albumina de $32 \mathrm{kDa}$ (denominada b-32) que tem um padrão de acúmulo coordenado com o acúmulo de zeínas no endosperma normal (Soave et al., 1981). A mutação o2 também afeta o catabolismo da lisina, causando uma diminuição na degradação de lisina solúvel no endosperma de milho (Sodek \& Wilson, 1970; Brochetto-Braga et al., 1992).

Damerval \& Guilloux (1998), analisaram o efeito da mutação o2 na expressão de proteínas durante o desenvolvimento das sementes de milho W64A, F2, F7, W22, B37 e OH43. Foram observados com expressão diminuída um polipeptídeo com similaridade na seqüência de aminoácidos a acetohidroxiacido sintase (AHAS) de milho que catalisa o primeiro passo na biossíntese de aminoácidos derivados do ramo da treonina e para a enzima citosólica ortofosfato diquinase (cyPPDK). Com expressão elevada foram identificados polipeptídeos com homologia as aspartatico proteinases que participa na degradação das proteínas de reserva durante o início da germinação, duas isoformas de gliceraldeído 3 fosfato desidrogenase envolvidas na glicolise no citosol, UDPglucuronosil transferase (UDPGT) catalisam a degradação de metabolitos tóxicos produzidos durante os processos de amadurecimento das sementes, e sorbitol desidrogenase responsável pela conversão de fructose em sorbitol que em principio pode ser convertida a glicose pela enzima aldosa redutase.

O mutante $f l 2$ parece atuar por um mecanismo diferente de aquele dos mutantes opaco, este gene mutante afeta cada grupo de zeínas de modo equivalente e causa uma maior ou menor redução no conteúdo de zeínas dependendo da doses do gene. Em contraste as formas discretas dos corpúsculos protéicos formados no endosperma de milho normal, no endosperma $f l 2$ os corpúsculos são irregulares e as zeínas estão desorganizadas (Lending \& Larkins, 1992). Outras caraterísticas da mutação fl2 é a presença de níveis diminuídos de polissomos unidos a membranas (Jones, 1978) e mRNAs de zeínas (Burr \& Burr, 1982), quando comparados ao endosperma normal. 
Uma associação foi observada entre o mutante $f l 2$ e a elevada produção de uma proteína solúvel com $\operatorname{Mr} 70000$, chamada de b-70 que se apresenta em duas isoformas b-70I e b70II, separáveis por eletroforese em gel bidimensional. Ambas isoformas estão expressadas 10 vezes a mais no mutante $f l 2$. A b-70 esta associada com os corpúsculos protéicos e a membrana do RER (Morocco et al., 1991). Embora, a função biológica desta proteína é desconhecida, ambas b-70I e b-70II, são muito similares a proteína HSP70 (heat shock protein) que unem ATP, reagem positivamente com anticorpos antiHSP e tem homologia com a sequiência N-terminal de HSP70. Todas as característica das b-70 associadas aos corpúsculos protéicos são típicos das chaperonas como HSPs. Uma terceira proteína, b-70III, similar em tamanho mas levemente mais acídica que B70I e b-70II, também se liga a ATP e reage com os mesmos anticorpos, provem evidência para a presença no endosperma de uma proteína chaperona citosólica (Morocco et al., 1991). Os níveis da proteína b-70III não foi alterada pelo gene mutante $f l 2$, por tanto o efeito de repressão da mutação $f l 2$ (como também $D e-B 30$ e $M c$ ) no acúmulo de zeínas poderia ser devido a alterações no transporte da zeínas ou no processo de ensamble das zeínas envolvendo b-70I e b-70II (Morocco et al., 1991).

Li \& Larkin (1996), isolaram e caraterizaram o cDNA da proteína dissulfeto isomerase (PDI). O Southern blot determinou que a PDI de milho é codificada por um simples gene localizado no braço curto do cromossomo 4. Estas proteínas estão associadas as cisternas e corpúsculos do RE. Durante o desenvolvimento do endosperma, os níveis de mRNA PDI aumentaram entre 10 e 14 DAP. Foi observado que nos mutantes $f l 2$ há um aumento na expressão de PDI, existindo uma correlação positiva entre os níveis de mRNAs e proteínas com a dosagem de alelos $f l 2$. O aumento de PDI é observado no RE, paralelamente a um aumento das proteínas BiP associadas a PDI, ambas estão ligadas aos corpúsculos protéicos do RE. As BiP são membros da família de chaperonas HSP70 e funcionariam facilitando a oligomerização e conformação das proteínas no lúmem do RE, removendo também aquelas proteínas que não estivarem pregadas. Os autores, propõem que a indução de PDI no mutante $f l 2$ reflete sue papel funcional como chaperona, e que PDI atuaria em conjunto com as 
proteínas $\mathrm{BiP}$ durante os diferentes estágios do processamento e ensamble das zeínas na construção dos corpúsculos protéicos. 


\title{
3 MATERIAL E MÉTODOS
}

\author{
$\underline{\text { Material Vegetal }}$
}

Foram usadas anteras imaturas e sementes de diferentes linhagens de Zea mays $(2 n=2 x=20)$. As sementes de milho foram cedidas pelo Maize Genetics COOP Stock Center (U.S.A) e foram escolhidas as sementes opaco: $o 1 ; o 2 ; o 5 ; o 7 ; o 10 ; o 11$ e $o 13$, e floury: $f l 1 f l 2$ e $f l 3$.

Os genótipos selvagens usados como controle das linhas mutantes foram Oh43 [Oh43/Oh43], B37 [B37/B37], W22 [W22/W22], B79 [B79/B77], WT3 [FL3/+].

Os mutantes $o 1, o 2$, fll e $f l 2$, foram obtidos a partir de Oh43; os mutantes $o 10$, $o 11$ e $o 13$ a partir de W22; o mutante $o 7$ de B37; o mutante $o 5$ originado de B79; e o mutante $f l 3$ de WT3.

As sementes foram cultivadas em casa-de-vegetação, durante o verão de 2001 no departamento de genética da ESALQ-USP. As plantas foram adubadas, antes do florescimento com $2 \mathrm{~g} / \mathrm{planta}$ de uréia, sendo realizadas 3 aplicações semanais. Posteriormente as plantas passaram a ser adubadas semanalmente com fertilizante foliar (Green-Top, Nutriplant) contendo NPK e micronutrientes. As plantas foram autofecundadas e as espigas com semente maduras foram coletadas e estocadas para análises posteriores.

As anteras foram coletadas e imediatamente colocadas em nitrogênio líquido e armazenadas em freezer a $-80^{\circ} \mathrm{C}$ ate serem usadas para análises. 
$\underline{\text { Extração de aminoácidos para análises por cromatografia em camada delgada }}$

A cromatografia em camada delgada (TLC) é uma técnica analítica prática, importante e amplamente usada (Berezkin \& Buzaev, 1997) para análises de alimentos e controle de qualidade (Sherma, 2000). Algumas vantagens têm justificado seu amplo uso, como a facilidade no uso de equipamentos e da técnica experimental, sua disponibilidade econômica e sua elevada produtividade (Sherma, 2000).

Aminoácidos solúveis foram extraídos a partir de 0,05 g de anteras. As amostras foram maceradas com um bastão de vidro em tubos eppendorf contendo $50 \mu 1$ de água Milli-Q. A seguir, os extratos foram centrifugados duas vezes à $15.000 \mathrm{rpm}$ em uma microcentrífuga por 15 minutos a $4{ }^{\circ} \mathrm{C}$. Os sobrenadantes fora m usados para análises de aminoácidos.

\section{$\underline{\text { Análises de aminoácidos por cromatografia em camada delgada }}$}

Para a análise qualitativa de aminoácidos foram utilizadas placas de sílica gel sobre poliéster de $20 \mathrm{~cm}$ x $20 \mathrm{~cm}$ (Sigma-Aldrich). Foram aplicadas alíquotas de $10 \mu 1$ dos extratos de anteras nas placas cromatograficas. Prévio a aplicação das amostras, as placas foram "ativadas" a $80{ }^{\circ} \mathrm{C}$ por 60 minutos.

Os cromatogramas foram realizados em cubas de vidro contendo álcool butílico, acetona, hidróxido de amônio e água deionizada nas proporções de 50:50:25:10 ml, respectivamente. Após a separação dos aminoácidos, as placas foram secas em estufa ventilada por 48 hs a temperatura ambiente e posteriormente revelados com uma solução de $0,2 \%$ de niidrina em acetona (p/v). Padrões foram incluídos para a identificação das bandas de aminoácidos. 
$\underline{\text { Extração de aminoácidos para análises por cromatografia líquida de alto }}$ desempenho (HPLC)

O procedimento para extração de aminoácidos por HPLC em fase reversa foi baseado na técnica publicada por Bielesky \& Turner (1986), com algumas modificações.

Foram usados $0,1 \mathrm{~g}$ de sementes que foram maceradas em nitrogênio líquido e em seguida, foram adicionados 2,0 ml da solução de extração MCW (12,0 ml de metanol, 5,0 $\mathrm{ml}$ de clorofôrmio e 3,0 $\mathrm{ml}$ de água bidestilada). A mistura foi incubada over-night a $4^{\circ} \mathrm{C}$ e posteriormente, centrifugada a $2500 \mathrm{rpm}$ por 20 minutos a $4^{\circ} \mathrm{C}$. Após a centrifugação, o sobrenadante foi misturado à $0,5 \mathrm{ml}$ de clorofôrmio e $0,75 \mathrm{ml}$ de água bidestilada. A solução foi centrifugada e o sobrenadante mantido a $38^{\circ} \mathrm{C}$ por 2 horas. Após a incubação, os extratos foram congelados em nitrogênio líquido e liofilizados por 48 horas. O resíduo de aminoácido foi resuspendido em $250 \mu 1$ de água milli-Q, posteriormente filtrado e $20 \mathrm{ul}$ na concentração de $125 \mathrm{nmol} / \mathrm{ml}$ foram utilizados para análises por HPLC.

$\underline{\text { Análise de aminoácidos solúveis por cromatografia líquida de alto desempenho }}$ (HPLC)

Os aminoácidos solúveis foram separados e analisados por HPLC de fase reversa. Foi utilizada uma coluna Spherisorb ODS-2 C18 e eluído em um gradiente linear formado pelas soluções de metanol $65 \%$ e tampão fosfato pH 7,5 (50 mM de acetato de sódio, $50 \mathrm{mM}$ de fosfato disódico, $1,5 \mathrm{ml}$ de ácido acético, $20 \mathrm{ml}$ de tetraidrofuram, $20 \mathrm{ml}$ de metanol) num fluxo de $0,8 \mathrm{ml} / \mathrm{min}$. O gradiente incrementou a proporção de metanol de $20 \%$ a $28 \%$ entre 0 e $5 \mathrm{~min}$, de $28 \%$ a $58 \%$ entre 5 e 35 min, de $58 \%$ a $75 \%$ entre 35 e $40 \mathrm{~min}, 75 \%$ a $95 \%$ entre 40 e $56 \mathrm{~min}, 95 \%$ a $96 \%$ entre 56 
a 60 min e $96 \%$ a $100 \%$ entre 60 e 61 min. O fluído da coluna foi monitorado por um detetor fluorescente Shimatdzu (model RF350) operando com um comprimento de onda de excitação de $250 \mathrm{~nm}$ e um comprimento de onda de emissão de $480 \mathrm{~nm}$. Foram misturados $20 \mu \mathrm{l}$ da solução de aminoácidos e $40 \mu \mathrm{l}$ do reagente OPA. Após 2 minutos foram injetados $20 \mu \mathrm{l}$ no aparelho de HPLC. Os dados são expressos em nmol/ml do sobrenadante e o \%mol do total de aminoácidos recuperados (excluindo prolina por não formar um derivado com OPA). Componentes dos reagentes ver Apendice.

\section{$\underline{\text { Análises estatísticas }}$}

Os dados foram analisados pelo procedimento de analise de variância e as médias foram comparadas utilizando diferenças mínimas significativas através do teste de Duncan para os níveis de probabilidade de $5 \%$ e $1 \%$. 


\section{RESULTADOS E DISCUSSÃO}

No presente trabalho foram determinados por HPLC os níveis de aminoácidos solúveis totais e os aminoácidos produtos da via metabólica do ácido aspártico em diversos genótipos de milho selvagens (W22, B37, B79, WT3 e Oh43) e diversos de seus mutantes, opaco $(o 1, o 2, o 5, o 7, o 10, o 11$ e $o 13)$ e floury $(f l 1, f l 2$ e $f l 3)$. A seguir serão detalhados os resultados obtidos quanto aos aminoácidos solúveis totais e especificamente dos aminoácidos lisina, metionina e treonina, de maior interesse já que são limitantes em termos de quantidades e diretamente relacionados à qualidade das proteínas da semente do milho para a alimentação humana. Os dados foram apresentados e discutidos tanto em valores absolutos $(\mathrm{nmol} / \mathrm{ml})$ como relativos $(\% \mathrm{~mol})$.

Mediante o uso da análise de variância, pode-se observar na Tabela 1, que os resultados referentes as quantidades absolutas indicaram que houve diferenças altamente significativas entre as sementes de diferentes linhagens para os aminoácidos totais (prob.> $\mathrm{F}=0,007$ ) e em relação aos níveis de metionina (prob. $>\mathrm{F}=0,010$ ), mas não houve diferenças entre as linhagens para os níveis de lisina (prob.>F=0,47) e treonina (prob. $>\mathrm{F}=0,78$ ) nas condições de realização dos experimentos.

No referente às proporções dos aminoácidos solúveis nas sementes (Tabela 2), puderam ser constatadas diferenças altamente significativas entre os genótipos para metionina (prob. $>\mathrm{F}=0,003$ ), mas não para lisina (prob. $>\mathrm{F}=0,72)$ ou treonina (prob. $>\mathrm{F}=$ $0,429)$.

Uma vez constatadas diferenças significativas, dando continuidade aos estudos, foram conduzidas análises de comparação de médias através do teste de Duncan. 
Tabela 1. Níveis de aminoácidos solúveis totais, lisina, treonina e metionina, em sementes maduras de genótipos de milho selvage ns e mutantes. Os dados foram expressos em valores absolutos (nmol/ml). Análise de Variância $(\mathrm{y}=\log$ $\mathrm{x}+10)$.

\begin{tabular}{|c|c|c|c|c|c|c|c|c|c|c|c|c|}
\hline & \multicolumn{3}{|c|}{ Aminoácidos Totais } & \multicolumn{3}{|c|}{ Lisina } & \multicolumn{3}{|c|}{ Metionina } & \multicolumn{3}{|c|}{ Treonina } \\
\hline F.V. & GL & $\overline{Q M}$ & Prob $>F^{a}$ & $\overline{G L}$ & $\overline{Q M}$ & Prob $>F^{a}$ & GL & $\overline{Q M}$ & Prob $>F^{a}$ & GL & $\overline{Q M}$ & Prob $>F^{a}$ \\
\hline Genótipos & 14 & 0,853 & 0,007 & 14 & 0,078 & 0,472 & 14 & 0,378 & 0,010 & 14 & 0,465 & 0,785 \\
\hline Resíduo & 19 & 0,259 & & 19 & 0,076 & & 19 & 0,118 & & 19 & 0,707 & \\
\hline Total & 33 & & & 33 & & & 33 & & & 33 & & \\
\hline Médias & & $6,70^{\circ}$ & & & 2,87 & & & 3,40 & & & 3,58 & \\
\hline C.V. $\%$ & & 7,438 & & & 9,60 & & & 10,0 & & & 23,45 & \\
\hline
\end{tabular}

a: Nível de significância $\alpha=0,05$ de probabilidade. 
Em relação aos níveis de aminoácidos solúveis totais, evidencia-se na Tabela 3, ao nível de 5\% de probabilidade, que as sementes das linhagens Oh43 e oll, diferenciam-se de um grupo constituído pelas linhagens mutantes $f l l$, $f l 3$ e selvagens B37, W22 e WT3. Este grupo apresentou níveis de aminoácidos nas sementes significativamente inferiores às linhagens Oh43 e $o 11$.

Buscando-se comparar os níveis de aminoácidos entre sementes de genótipos selvagens e mutantes, observou-se que os genótipos selvagens, de fato, apresentaram níveis inferiores de aminoácidos, com diferenças significativas com relação aos genótipos mutantes, com a exceção da linhagem Oh43. As sementes opaco comparadas às sementes selvagens foram caracterizadas como um grupo homogêneo, observando-se diferenças estatísticas e superioridade de diversos mutantes com relação às sementes de milho selvagens, com exceção da linhagem Oh43. As sementes mutantes floury não se diferenciaram significativamente das sementes das linhagens normais de modo superior em nenhum caso. As sementes opaco, quando comparadas com as sementes floury, tenderam a apresentar níveis mais elevados de aminoácidos solúveis totais, sem diferenças estatisticamente significativas apenas em relação a semente $f l 2$ que se apresentou entre o grupo dos mutantes opaco. Quando comparadas as sementes opaco entre si e as sementes floury entre si, foi observado que não diferiram estatisticamente, ainda que as sementes $f l 2$ possam ser agrupadas entre as linhagens com valores significativamente superiores aos outros mutantes floury.

Comparando-se especificamente sementes de linhagens selvagens e dos mutantes aos quais deram origem, observou-se (Tabela 3) que as sementes do genótipo selvagem Oh43, que originou os mutantes $o 1, o 2$ e $o 13$, não diferiram significativamente para os níveis de aminoácidos solúveis totais. Comparando essa linhagem selvagem com os mutantes $f l l$ e $f l 2$, observou-se que as sementes Oh43 foram significativamente superiores a $f l l$ e não diferiram estatisticamente de $f l 2$. 
Tabela 2. Níveis de lisina, metionina e treonina solúveis em genótipos de milho selvagens e mutantes. Os dados expressos em valores relativos (\%mol). Análise de variância $(\mathrm{y}=\log \mathrm{x}+10)$.

\begin{tabular}{lccccccccc}
\hline & \multicolumn{3}{c}{ Lisina } & \multicolumn{3}{c}{ Metionina } & \multicolumn{3}{c}{ Treonina } \\
\hline F.V. & GL & QM & Prob>F & GL & QM & Prob>F & GL & QM & Prob>F \\
\hline Genótipos & 14 & 0,008 & 0,720 & 14 & 0,378 & 0,003 & 14 & 0,079 & 0,429 \\
Resíduo & 20 & 0,011 & & 20 & 0,009 & & 18 & 0,072 & \\
Total & 34 & & & 34 & & & 34 & & \\
Média & & 3,315 & & & 3,530 & & 3,612 & \\
C.V. \% & & 3,197 & & 2,723 & & 7,452 & \\
\hline
\end{tabular}

a: Nível de significância $\alpha=0,05$ de probabilidade.

Tabela 3. Médias de aminoácidos solúveis totais em genótipos de milho selvagens e mutantes. Os dados foram expressos em valores absolutos (nmol/ml). Diferenças significativas foram analisados pelo teste de Duncan.

\begin{tabular}{lcccc}
\hline Genótipos & $\begin{array}{c}\text { Médias } \\
\text { originais }\end{array}$ & $\begin{array}{c}\text { Médias } \\
\log (\mathrm{x}+10)\end{array}$ & $5 \%$ & $1 \%$ \\
\hline Oh43 & 2501,35 & 7,829 & $\mathrm{a}$ & $\mathrm{A}$ \\
opaco-11 & 1898,84 & 7,554 & $\mathrm{a}$ & $\mathrm{A}$ \\
opaco-13 & 1758,80 & 7,478 & $\mathrm{ab}$ & $\mathrm{A}$ \\
opaco-2 & 1674,76 & 7,429 & $\mathrm{ab}$ & $\mathrm{A}$ \\
opaco-5 & 1174,30 & 7,077 & $\mathrm{abc}$ & $\mathrm{AB}$ \\
floury-2 & 748,06 & 6,631 & $\mathrm{abcd}$ & $\mathrm{AB}$ \\
opaco-1 & 725,03 & 6,600 & $\mathrm{abcd}$ & $\mathrm{AB}$ \\
opaco-7 & 646,55 & 6,487 & $\mathrm{abcd}$ & $\mathrm{AB}$ \\
opaco-10 & 592,57 & 6,401 & $\mathrm{abcd}$ & $\mathrm{AB}$ \\
B79 & 501,07 & 6,237 & $\mathrm{abcd}$ & $\mathrm{AB}$ \\
floury-3 & 493,67 & 6,222 & $\mathrm{bcd}$ & $\mathrm{AB}$ \\
floury-1 & 479,30 & 6,191 & $\mathrm{bcd}$ & $\mathrm{AB}$ \\
B37 & 442,40 & 6,115 & $\mathrm{bcd}$ & $\mathrm{AB}$ \\
W22 & 292,28 & 5,711 & $\mathrm{~cd}$ & $\mathrm{AB}$ \\
WT3 & 207,21 & 5,381 & $\mathrm{~d}$ & $\mathrm{~B}$ \\
\hline
\end{tabular}

Obs: Médias seguidas de letras diferentes indicam diferenças significativas para os níveis de probabilidade utilizados. 
Comparando-se os níveis de aminoácidos das sementes mutantes o10, oll e o13 originadas da linhagem W22, ao contrário dos exemplos anteriores, foram verificados diferenças significativos das sementes mutantes com valores de 592,57, 1758,80 e $1898,84 \mathrm{nmol} / \mathrm{ml}$, superiores aos observados nos genótipo selvagem $(292,28 \mathrm{nmol} / \mathrm{ml})$.

As sementes da linhagem WT3 mostraram quantidades inferiores de aminoácidos solúveis totais em relação ao mutante $f l 3$, mas não apresentaram diferenças estatísticas significativas com valores entre 207,21 e 493,67 nmol/ml, respectivamente. O mesmo comportamento pôde ser observado quando comparadas as sementes da linhagem B79 $(501,07 \mathrm{nmol} / \mathrm{ml})$ e $o 5(1174,76 \mathrm{nmol} / \mathrm{ml})$ e as linhagens $\mathrm{B} 37(442,40 \mathrm{nmol} / \mathrm{ml})$ e $o 7$ $(646,55 \mathrm{nmol} / \mathrm{ml})$. Os mutantes apresentaram quantidades maiores de aminoácidos, mas sem diferirem entre eles, nas condições das análises experimentais.

Ao nível de $1 \%$ de probabilidade apenas as sementes das linhagens Oh43, oll, $o 13$ e $o 2$, foram superiores e se diferenciaram significativamente das sementes da linhagem WT3, inferior em termos de níveis de aminoácidos solúveis totais. Os genótipos restantes, caracterizaram um grupo intermediário que não diferem estatisticamente das quatro linhagens acima citadas.

No que se refere aos níveis absolutos de metionina (Tabela 4), ao nível de 5\% de probabilidade, obtiveram destaque as sementes $o 2$ sem entretanto diferir estatisticamente das linhagens $\mathrm{Oh} 43$ e dos mutantes $o 11, o 13$ e $o 5$. Comparando-se de forma global as sementes selvagens e sementes mutantes, verificourse que novamente houve concentração das sementes selvagens nos menores valores, sem diferir estatisticamente dos demais mutantes à exceção do já citado $o 2$. De modo geral, o mesmo é válido para uma comparação entre sementes selvagens e opacos e para selvagens e mutantes floury, para níveis de metionina expressos em $\mathrm{nmol} / \mathrm{ml}$.

Detalhando as observações nos grupos constituídos por sementes de uma linhagem selvagem e as sementes mutantes originadas, observou-se (Tabela 4), que o selvagem Oh43 apresentou valores absolutos inferiores de metionina comparado à sementes $o 2$, sem diferir estatisticamente do mesmo. Entretanto, Oh43 foi superior a o13, mas também sem diferir significativamente do mesmo. O contrário foi constatado com ol, que apresentou $10,63 \mathrm{nmol} / \mathrm{ml}$ de metionina que foi estatisticamente inferior à 
linhagem Oh43 (63,10 nmol/ml). Comparando essa linhagem selvagem com os mutantes floury, verificourse que as sementes selvagens foram significativamente superio res a $f l l$ e $f l 2$. Neste caso, não foi registrado superioridade das sementes mutantes para níveis de metionina solúvel. As sementes mutantes ol0 (17,66 nmol/ml), oll (36,79 nmol/ml) e ol3 $(29,40 \mathrm{nmol} / \mathrm{ml})$ não apresentaram aumentos significativos de metionina com relação a W22, ainda que a linhagem selvagem tenha apresentado níveis inferiores correspondentes a 10,66 nmol/ml. Da mesma forma que para níveis de aminoácidos solúveis totais, a linhagem selvagem WT3 mostrourse inferior, mas não diferiu significativamente do mutante $f l 3$ e novamente, o mesmo ocorreu com as sementes selvagem B79 quando comparadas às mutantes o5, como também não diferem as linhagens B37 e 07.

Tabela 4. Médias de metionina livre em genótipos de milho selvagens e mutantes. Os dados foram expressos em valores absolutos (nmol $/ \mathrm{ml})$. Diferenças significativas foram analisadas por teste de Duncan.

\begin{tabular}{lcccc}
\hline Genótipos & $\begin{array}{c}\text { Médias } \\
\text { originais }\end{array}$ & $\begin{array}{c}\text { Médias } \\
\log (\mathrm{x}+10)\end{array}$ & $5 \%$ & $1 \%$ \\
\hline opaco-2 & 64,53 & 4,311 & $\mathrm{a}$ & $\mathrm{A}$ \\
Oh43 & 64,48 & 4,311 & $\mathrm{a}$ & $\mathrm{AB}$ \\
opaco-11 & 36,79 & 3,846 & $\mathrm{ab}$ & $\mathrm{AB}$ \\
opaco-13 & 29,40 & 3,674 & $\mathrm{abc}$ & $\mathrm{AB}$ \\
opaco-5 & 27,97 & 3,637 & $\mathrm{abc}$ & $\mathrm{AB}$ \\
opaco-10 & 17,66 & 3,320 & $\mathrm{bc}$ & $\mathrm{AB}$ \\
floury-2 & 16,06 & 3,260 & $\mathrm{bc}$ & $\mathrm{AB}$ \\
floury-1 & 15,89 & 3,254 & $\mathrm{bc}$ & $\mathrm{AB}$ \\
floury-3 & 14,91 & 3,215 & $\mathrm{bc}$ & $\mathrm{AB}$ \\
B79 & 12,68 & 3,121 & $\mathrm{bc}$ & $\mathrm{AB}$ \\
WT3 & 11,36 & 3,061 & $\mathrm{bc}$ & $\mathrm{AB}$ \\
opaco-7 & 11,27 & 3,057 & $\mathrm{bc}$ & $\mathrm{AB}$ \\
opaco-1 & 10,63 & 3,027 & $\mathrm{bc}$ & $\mathrm{AB}$ \\
W22 & 10,17 & 3,004 & $\mathrm{bc}$ & $\mathrm{AB}$ \\
B37 & 5,29 & 2,727 & $\mathrm{c}$ & $\mathrm{B}$ \\
\hline
\end{tabular}

Obs: Médias seguidas de diferentes letras indicam diferenças significativas para os níveis de probabilidade utilizados. 
Ao nível de $1 \%$ de probabilidade (Tabela 4), pode-se destacar o o2 que apresentou o maior valor, correspondente a 64,53\% $\%$, e foi significativamente diferente de B37 que apresentou o menor valor, correspondente a 5,29 \% mol. Todos os demais genótipos não apresentaram diferenças significativas em relação ao maior e ao menor valor de metionina. Os demais genótipos se posicionaram intermediariamente, não diferindo nem do maior, nem do menor valor de metionina.

Na Tabela 5, estão representados os valores relativos de metionina. Pode ser verificado que a linhagem WT3, que apresentou valores absolutos inferiores de aminoácidos solúveis totais e metionina, apresentou a maior proporção desse aminoácido nas sementes quando comparada com as demais linhagens estudadas, diferindo de todas exceto das sementes $o 2$ e W22 ao nível $\alpha=0,05$ de significância. É interessante salientar, que em termos de quantidade relativa de metionina, as sementes selvagens distribuem-se amplamente entre as sementes mutantes, sem caracterizar um grupo superior ou inferior com relação aos mutantes. Observando-se os valores relativos de metionina para sementes selvagens e opaco, salvo as exceções já comentadas, pôde ser observado um agrupamento de sementes opaco com proporções inferiores, sem entretanto existir diferenças significativas. As sementes floury foram distribuídas amplamente entre as sementes selvagens e apresentaram proporções de metionina superiores à maioria das sementes opaco, mas novamente não foram registradas diferenças estatísticas entre estas, ainda que as sementes $f l l$ e $f l 2$ possam ser agrupadas em um conjunto distinto do formado por sementes opaco com proporções inferiores de metionina solúveis.

Verificourse que as sementes selvagens Oh43 com 2,58\%mol de metionina, tiveram um desempenho superior, mas não diferiram dos mutantes $o 13(1,82 \% \mathrm{~mol})$ e $o 1$ $(1,56 \% \mathrm{~mol})$. Apesar do mutante o2 ocupar um nível superior, não foram observadas diferenças estatísticas das sementes o2 com 3,65 \%mol de metionina quando comparadas as sementes Oh43. Em relação aos mutantes fll $(3,37 \%$ mol) e $f l 2(2,07$ \%mol), não houve diferenças estatísticas, situando-se os valores das sementes Oh43 entre os valores das sementes mutantes. 
A linhagem W22 com 3,48 \%mol de metionina, também não apresentou diferenças com seus mutantes $010, o 11$ e $o 13$, ainda que tenha apresentado valores superiores aos mesmos e possa ser agrupada juntamente com o10 com 2,99\%mol de metionina, superiores aos outros dois mutantes.

Tabela 5. Médias de metionina solúveis em genótipos de milho selvagens e mutantes. Os dados foram expressados em valores relativos (\% mol). Diferenças significativas foram analisadas pelo teste de Duncan.

\begin{tabular}{lcccc}
\hline Genótipos & $\begin{array}{c}\text { Médias } \\
\text { originais }\end{array}$ & $\begin{array}{c}\text { Médias } \\
\log (\mathrm{x}+10)\end{array}$ & $5 \%$ & $1 \%$ \\
\hline WT3 & 5,48 & 3,934 & $\mathrm{a}$ & $\mathrm{A}$ \\
opaco-2 & 3,65 & 3,685 & $\mathrm{ab}$ & $\mathrm{AB}$ \\
W22 & 3,48 & 3,672 & $\mathrm{abc}$ & $\mathrm{AB}$ \\
floury-1 & 3,37 & 3,657 & $\mathrm{bc}$ & $\mathrm{AB}$ \\
opaco-10 & 2,99 & 3,605 & $\mathrm{bc}$ & $\mathrm{AB}$ \\
floury-3 & 2,78 & 3,575 & $\mathrm{bc}$ & $\mathrm{AB}$ \\
Oh43 & 2,58 & 3,547 & $\mathrm{bc}$ & $\mathrm{AB}$ \\
B79 & 2,53 & 3,540 & $\mathrm{bc}$ & $\mathrm{AB}$ \\
floury-2 & 2,07 & 3,474 & $\mathrm{c}$ & $\mathrm{B}$ \\
opaco-11 & 2,00 & 3,463 & $\mathrm{c}$ & $\mathrm{B}$ \\
opaco-5 & 1,82 & 3,438 & $\mathrm{c}$ & $\mathrm{B}$ \\
opaco-13 & 1,82 & 3,438 & $\mathrm{c}$ & $\mathrm{B}$ \\
opaco-7 & 1,74 & 3,426 & $\mathrm{c}$ & $\mathrm{B}$ \\
opaco-1 & 1,56 & 3,400 & $\mathrm{c}$ & $\mathrm{B}$ \\
B37 & 1,19 & 3,345 & $\mathrm{c}$ & $\mathrm{B}$ \\
\hline
\end{tabular}

Obs: Médias seguidas de diferentes letras indicam diferenças significativas para os níveis de probabilidade utilizados.

Comprando-se os 5,48 \% mol de metionina da linhagem WT3 com os 2,78 \% mol da sementes $f l 3$, constatou-se que a linhagem selvagem apresentou significativamente maior proporção de metionina que seu mutante. Já as sementes B79 foram superiores mas não diferiram do mutante $o 5$, com proporções de 2,53 \%mol e 1,82 \%mol de metionina, respectivamente. Nas sementes B37 as proporções correspondentes a 1,19 
\%mol foram inferiores, mas não diferiram estatisticamente dos mutante o7 que registraram uma valor de $1,74 \%$ mol de metionina.

Ao nível de $1 \%$ de probabilidade destaca-se a linhagem WT3, sem entretanto diferir das sementes $o 2$, W22, $f l 1, o 10, f l 3$, Oh43, e B79. Este grupo de genótipos e as linhagens restantes com valores inferiores de metionina, formaram um conjunto de valores que não diferem estatisticamente entre si.

Finalmente, utilizando extratos de anteras, foi realizado uma separação de aminoácidos solúveis por TLC (Figura 1). Os resultados obtidos neste trabalho, não permitiram discernir entre os genótipos mutantes e os selvagens que lhes deram origem, para níveis de lisina solúveis nas condições de realização do experimento. Com exceção de B79 e o5, sendo a linhagem mutante a que apresentou bandas menores e menos intensa.

Analisando-se os níveis de metionina em relação ao total de aminoácidos das amostras (Tabela 5), a diversidade dos valores obtidos sugerem diferentes distribuições de aminoácidos solúveis entre as linhagens estudadas. É interessante também ressaltar, que neste trabalho foram analisados os níveis de aminoácidos solúveis que representam entre 6-8\% do total de aminoácidos da semente normal. Isto sugere que poderia ser interessante analisar o conjunto todo de aminoácidos, solúveis e incorporados à proteínas, tanto qualitativa como quantitativamente e compara-los ao perfil de aminoácidos de uma proteína padrão, de origem animal, com elevado valor bioló gico, por exemplo as proteínas do leite ou as proteínas do ovo de galinha. Isto poderia permitir-nos evidenciar informações complementares e relevantes referentes aos perfis de aminoácidos e valor biológico das proteínas das linhagens estudadas.

Por outro lado, as diferenças observadas entre os valores médios de cada genótipo analisado, estabelecem que seria interessante repetir os experimentos apresentados com maior número de repetições para que se pudesse evidenciar melhor as diferenças entre as linhagens e minimizar aquelas existentes entre diferentes repetições de um mesmo tratamento. De fato, como pode ser observado na Tabela 4, a linhagem WT3, que apresentou valores inferiores nas análises de aminoácidos solúveis totais e metionina, apresentou entretanto a maior proporção desse aminoácido quando comparadas com as 
demais linhagens estudadas, ao nível de $5 \%$ de probabilidade. Deste modo, se em termos absolutos esse valor era um dos menores, pode-se supor muito maior quantidade de aminoácidos entre os endospermas de outras linhagens, como por exemplo o2 ou o1 1 que apresentaram os maiores níveis de metionina em termos absolutos, excetuando Oh43.

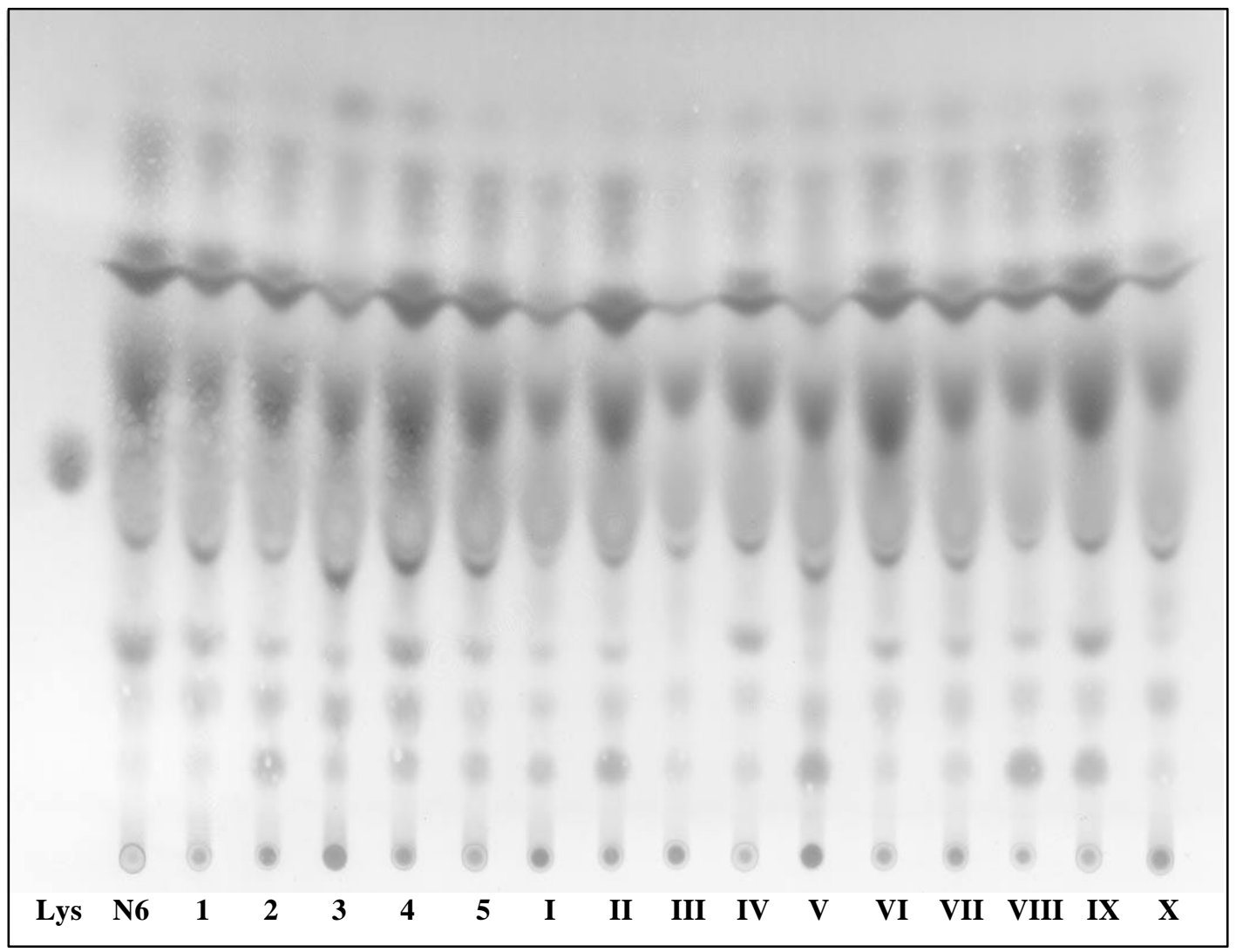

Figura 4. Análise de lisina livre de anteras de genótipos de milho selvagens e mutantes por TLC. Lys: lisina, N6: variedade da ESALQ. Genótipos controles:, 1 (W22), 2 (Oh43), 3 (WT3), 4 (B79) e 5 (B37). Genótipos mutantes: I (o1), II (o2), III (o5), IV (o7), V (o10), VI (o11), VII (o13), VIII (fl1), IX (fl2) e X (fl3). 
Neste informe, não foram registrados valores superiores de lisina solúvel nas sementes mutantes com relação as sementes selvagens de milho que lhes deram origem diferindo de trabalhos publicados onde foram observadas diferenças consistentes, com quantidades maiores de lisina nos mutantes (Sodek \& Wilson, 1975; Gaziola et al., 1999; Wang \& Larkins, 2001). No entanto, a maioria das pesquisas foram direcionadas a informar sobre o conteúdo de aminoácidos totais dos endospermas de milho, considerando-se em conjunto os níveis de aminoácidos livres e aminoácidos incorporados às proteínas (Ma \& Nelson, 1975; Misra et al., 1975, Balconi et al., 1998). Um estudo recente, realizado por Wang e Larkins (2001), informaram níveis elevados de lisina solúvel em endosperma maduro da linhagem W64Ao2 quando comparadas as linhagens selvagens.

No caso dos mutantes floury, tem sido observado que endospermas fl2 são inferiores em proporção de aminoácidos livres (Sodek \& Wilson, 1971) e superiores em quantidade de aminoácidos totais em endospermas R802 (Sodek \& Wilson, 1971) e milho Oh43 (Misra et al., 1975), em endosperma mutante fl3, não foram informados análises de aminoácidos solúveis, mas foram realizados a partir de hidrólises ácida (Ma \& Nelson, 1975) e técnicas colorimétricas (Balconi et al., 1998) de proteínas de reserva, registrando-se aumentos na proporção de lisina com relação as quantidades presentes no endospermas selvagens. Balconi et al. (1998), determinaram também níveis maiores de lisina no endosperma de A69yol e A69yo11. Por hidrólises ácida foram também determinados os níveis de aminoácidos no endosperma o7 e comparados a linhagem W22 que lhe deu origem (Ma \& Nelson, 1975).

Provavelmente, a não diferença nos níveis de lisina livres entre as diferentes linhagens possa ser devido a utilização de sementes inteir as de milho como material de estudo, ao invés de endospermas isolados como a maioria das publicações anteriores (Sodek \& Wilson, 1975; Gaziola et al., 1999), o que poderia causar uma "diluição" dos aminoácidos livres totais. Assim, diferentes tecidos envolvidos levariam a subestimar as quantidades reais de aminoácidos livres dos endospermas mutantes em relação aos genótipos normais. Naturalmente, nas sementes maduras de milho analisadas os níveis 
de lisina solúvel deveriam ser muito baixos e possivelmente diretamente associados a taxa do metabolismo das proteínas de reserva para fornecer nitrogênio ao embrião.

Interessantemente, as diferenças mais acentuadas nas quantidades de aminoácidos livres entre linhagens mutantes e selvagens, foram reportadas ser durante o desenvolvimento do endosperma, conseqüência do transporte de aminoácidos desde a seiva para as células do endosperma, além da síntese in situ (Silva \& Arruda, 1979) e coordenado com a síntese de proteínas de reservas da semente de milho. Em endospermas em desenvolvimento de milho o2 os níveis elevados de lisina (Silva \& Arruda, 1979; Gaziola et al., 1999) concordaram com a síntese diminuída das proteínas zeínas (Sodek \& Wilson, 1975; Yau et al., 1999) e com uma menor atividade da enzima LOR/SDH (Brochetto-Braga et al., 1992; Gaziola et al., 1999). No entanto, a atividade desta proteína bifuncional durante o processo de maturação da semente degradaria a lisina não incorporada às proteínas diminuindo mais ainda sua quantidade no grão (Galili, 1995).

Também não foram registradas diferenças consistentes para quantidades de treonina solúveis neste trabalho os que concordaram com resultados obtidos anteriormente em endosperma de milho R802o2 (Sodek \& Wilson, 1971) e endosperma W64Ao2 (Wang e Larkins, 2001). № entanto diferiram grandemente dos resultados obtidos para endosperma Oh545o2 com aumentos significativos de treonina solúvel (Wang \& Larkins, 2001). Isto sugere dois aspectos importantes, primeiramente revela a importância da interação entre o gene $o 2$ e o "background" genético onde serão expressados e avaliados os seus efeitos fenotípicos e ao mesmo tempo nos alerta sobre uma possível perda de aminoácidos durante o processo de extração. $\mathrm{Na}$ literatura somente foi informado aumentos de 144 vezes de treonina solúvel mas não de lisina e metionina, a partir de endospermas de mutantes bioquímicos de milho contendo $\mathrm{AK}$ insensíveis a retroinibição por lisina (Azevedo et al., 1990).

A análise qualitativa de lisina solúvel a partir de anteras por TLC não permitiram diferenciar entre plantas mutantes e selvagens que lhes deram origem. Realizamos este experimento baseados num trabalho de Azevedo et al., (1990), que identificaram plantas heterozigotas e homozigotas resultantes de um cruzamento entre plantas o2 e askl, 
mostrando que as plantas Ltr1ltr1/o2o2 e somente uma planta ltr1ltr1/o2o2 apresentaram níveis maiores de treonina solúvel quando comparadas com o genótipo selvagem que lhe deu origem. 


\section{CONCLUSÕES}

- Os mutantes opaco e floury que foram seleccionados e classificados como de alto valor nutritivo devido as concentrações elevadas de lisina, não apresentaram valores significativos para os níveis de lisina solúvel no endosperma de sementes maduras

- Em relação aos níveis de aminoácidos solúveis totais apenas os mutantes o10, ol1 e o13, foram estatisticamente superiores a linhagem selvagem W22. Não houve difereças entre as restantes genótipos mutantes e selvagens que lhes deran origem.

- Não foram observadas diferênças significativas entre os diferentes genótipos para quantidades de treonina sóluvel no endosperma de sementes maduras.

- Somente foram observadas diferenças significativas para metionina solúvel entre a linhagem selvagem Oh43, com quantidades superiores, e $f l 1$ e $f l 2$. 


\section{REFERÊNCIAS BIBLIOGRÁFICAS}

AARNES, H. Lysine-Sensitive Aspartate Kinase and 2 Molecular-forms of Homoserine Dehydrogenase from barley seedlings. Plant Science Letters, v.9, n.2, p.137-145, 1977.

AARNES, H.; ROGNES, S.E. Threonine-sensitive aspartate kinase and homoserine dehydrogenase from Pisum sativum. Phytochemistry, v.13, p.2717-2724, 1974.

ARRUDA, P.; KEMPER, A.L.; PAPES, F.; LEITE, A. Regulation of lysine catabolism in higher plants. Trends in Plant Science, v.5, n.8, p.324-330, 2000.

ARRUDA, P.; DA SILVA, W.J. Lysine-ketoglutarate reductase activity in maize: its possible role in lysine metabolism of developing endosperm. Phytochemistry, v.22, n.12, p.2687-2689, 1983.

ARRUDA, P.; BRIGHT, S.W.J.; KUEH, J.S.H.; LEA, P.J.; ROGNES S.E. Regulation of aspartate kinase isoenzymes in barley mutants resistant to lysine plus threonine construction and analysis of combinations of the $1 \mathrm{t} 1 \mathrm{a}, 1 \mathrm{t} 1 \mathrm{~b}$, and $1 \mathrm{t} 2$ mutant-genes. Plant Physiology, v.76, n.2, p.442-446, 1984.

ARRUDA, P.; SODEK, L.; DA SILVA, W.J. Lysine-ketoglutarate reductase activity in developing maize endosperm. Plant Physiology, v.69, p.988-989, 1982. 
AZEVEDO, R.A.; ARANA, J.L.; ARRUDA, P. Biochemical genetics of the interaction of the lysine plus threonine resistant mutant $l t r * 1$ with opaque-2 maize mutant. Plant Science, v.70, p.81-90, 1990.

AZEVEDO, R.A.; ARRUDA, P. Dominant and recessive mutations conferring resistance to s2-aminoethyl-1-cysteine in maize. Journal of Plant Physiology. v.145, p.321-326, 1995.

AZEVEDO, R.A.; ARRUDA, P.; TURNER, W.L.; LEA, J.P. The biosynthesis and metabolism of the aspartate derived amino acids in higer plants. Phytochemistry, v.46, n.3, p.395- 419, 1997.

AZEVEDO, R.A.; BLACKWELL, R.D.; SMITH, R.J.; LEA, P.J. Three aspartate kinase isoenzimas from maize. Phytochemistry, v.31, n.11, p.3725- 3730, 1992a.

AZEVEDO, R.A.; SMITH, R.J.; LEA, P.J. Aspartate kinase regulation in maize: Evidence for co-purification of threonine-sensitive aspartate kinase and homoserine dehidrogenase. Phytochemistry, v.31, n.11, p.3731- 3734, 1992b.

AZEVEDO, R.A.; SMITH, R.J.; LEA, P.J. Aspartate kinase regulation in maize: regulation by calcium and calmodulin. Phytochemistry, v.31, n.11, p.3735-3737, 1992c.

BALCONI, C.; BERARDO, N.; REALI, A.; MOTTO, M. Variation in protein fraction and nitrogen metabolism of developing normal and opaque endosperm mutants of maize. Maydica, v.43, n.3, p.195-203, 1998.

BASS, H.W.; WEBSTER, C.; OBRIAN, G.R.; ROBERTS, J.K.M.; BOSTON, R. A Maize Ribosome-Inactivating Protein Is Controlled by the Transcriptional Activator Opaque-2. The Plant Cell, v.4, p.225-234, 1992. 
BEREZKIN, V.G.; BUZAEV, V.V. New thin-layer chromatography plate with a closed sorbent layer and details of its application. Journal of Chromatography, v.758, p.125-134, 1997.

BIELESKY, R.L.; TURNER, N.A. Separation and estimation of amino acids in crude plant extracts by thin-layer electrophoreses and chromatography. Analytical Biochemistry, v.17, n.2, p.278-293, 1966.

BOYES, C.J.; VASIL, L.K. In vitro selection for tolerance to S-(2-aminoethyl)-Lcysteine and overproduction of lysine by embryogenic calli and regenerated plants of Pennisetum americanum (L) K. Shum. Plant Science, v.50, p.195-203, 1987.

BRANDT, A.B. In vivo incorporation of lysine- $\mathrm{C}^{14}$ into the endosperm proteins of wild type and high lysine barley. FEBS Letters, v.52, p.288-291, 1975.

BRENNECKE, K.A.; SOUZA NETO, J.A.; LUGLI, J.; LEA, P.J.; AZEVEDO, R.A. Aspartate kinase in the maize mutants Ask1-LT19 and Opaque-2. Phytochemistry, v.41, p.707-712, 1996.

BRIGHT, S.W.J.; MIFLIN, B.J.; ROGNES, S.E. Threonine accumulation in the seed of a barley mutant with an altered aspartate kinase. Biochemical Genetics, v.20, p.229-243, 1982a.

BRIGHT, S.W.J.; MIFLIN, B.J.; ROGNES, S.E. Two genes for threonine accumulation in barley seeds. Nature, v.299, p.278-279, 1982 b.

BRINCH-PEDERSEN, H.; GALILI, G.; KNUDSEN, S.; HOLM, P.B. Engineering of the aspartate family biosynthetic pathway in barley (Hordeum vulgare L.) by transformation with heterologous genes encoding feed-back-insensitive aspartate kinase and dihydrodipicolinate synthase. Plant Molecular Biology, v.32, p.611620, 1996. 
BROCHETTO-BRAGA, M.R., LEITE, A.; ARRUDA, P. Partial purification and characterization of lysine-ketoglutarate reductase in normal and opaque-2 maize endosperms. Plant Physiology, v. 98, p.1139-1147, 1992.

BRYAN, J.K. Differencial regulation of maize homoserine dehydrogenase under physiological conditions. Plant Physiology, v.92, p.785-791, 1990.

BRYAN, P.A.; CAWLEY, R.D.; BRUNNER, C.E.; BRYAN, J.K. Isolation and characterization of a lysine-sensitive aspartatokinase from a multicelular plant. Biochemical and Biophysical Research Communications, v.41, n.5, p.1211-1217, 1970.

BRYAN, J.K.; LOCHNER, N.R. Quantitative estimates of the distribution of homoserine dehydrogense isozyme in maize tissues. Plant Physiology, v.68, p.1400-1405, 1981.

BURR, F. A.; BURR, B. Three mutations in zea mays affecting zein accumulation: a comparison of zein polypeptides, in vitro sinthesis and processing, mRNA levels, and genomic organization. The Journal of Cell Biology, v. 94, p.201-206, 1982.

CICERI,. P.; LOCATELLI, F.; GENGA, A.; VIOTTI, A.; SCHMIDT, R.J. The activity of the maize opaque2 transcriptional activator is regulated diurnally. Plant Physiology, v. 121, p.1321-1327, 1999.

CICERI, P.; GIANAZZA, E.; LAZZARI, B.; LIPPOLI, G.; GENGA, A.; HOSCHEK G.; SCHMIDT, R. J.; VIOTTI, A. Phosphorylation of opaque 2 changes diurnally and impacts its dna binding activity. The Plant Cell, v. 9, p.97-108, 1997. 
CORD NETO, G.; YUNES, J.A.; VETTORE, A.L.; DA SILVA, W.J.; ARRUDA, P.; LEITE, A. The involvement of Opaque 2 in $\beta$-prolamin gene regulation in maize and Coix suggests a more general role for this transcriptional activator. Plant Molecular Biology, v.27, p.1015-1029, 1995.

DAMERVAL, C.; LE GUILLOUX, M. Characterization of novel proteins affected by o2 mutation and expressed during maize endosperm development. Molecular \& General Genetic, v. 257, n.3, p.354-361, 1998.

DANTE, R.A.; CORD NETO, G.; LEITE, A.; YUNES, J.A.; ARRUDA, P. Tha DapA gene encoding the lysine biosynthetic enzyme dihidrodipicolinate synthase from Coix lacryma-jobi: cloning, characterization, and expression analysis. Plant Molecular Biology, v. 41, p.551-561, 1999.

DA SILVA, W.J.; ARRUDA, P. Evidence for the genetic control of lysine catabolism in maize endosperm. Phytochemistry, v. 18, p.1803-1805, 1979.

DAVIES, H.M.; MIFLIN, B.J. Aspartate kinase from carrot cell suspension culture. Plant Science Letter, v. 9, p.323-332, 1977.

DAVIES, H.M.; MIFLIN, B.J. Regulatory Isoenzymes of Aspartate Kinase and the Control of Lysine and Threonine Biosynthesis in Carrot Cell Suspension Culture. Plant Physiology, v.62, p.536-542, 1978.

DEREPPE, C.; BOLD, G.; GHISALBA, O.; EBERT, E.; SCHAR, H.-P. Purification and characterization of dihydrodipicolinate synthase from pea. Plant Physiology, v.98, p.813-821, 1992.

DI FONZO, N.; FORNASARI, E.; SALAMINI, F.; REGGIANI, R.; SOAVE, C. Interaction of maize mutants floury- 2 and opaque- 7 with opaque 2 in the synthesis of endosperm proteins. The Journal of Heredity, v. 71, p.397-402, 1980. 
DOLFINI, S.F.; LANDONI, M.; TONELLI, C.; BERNARD, L.; VIOTTI, A. Spatial regulation in the expression of estructural and regulatory storage-protein genes in Zea mays endosperm. Developmental Genetics, v.13, p.264-276, 1992.

DOTSON, S. B.; FRISCH, D. A.; SOMERS, D. A.; GENGENBACH, B. G. Lysineinsensitive aspartate kinase in two threonine-overproducing mutants of maize. Planta, v. 182, p.546-552, 1990.

EPELBAUM, S.; McDEVITT, R.; FALCO, S.C. Lysine-ketoglutarate reductase and saccharopine dehydrogenase from Arabidopsis thaliana: Nucleotide sequence and characterization. Plant Molecular Biology, v. 35, p.735-748, 1997.

FALCO, S.C.; GUIDA, T.; LOCKE, M.; MAUVAIS, J.; SANDERS, C.; WARD, R.T.; WEBBER, P. Transgenic Canola and Soybean Seeds with Increased Lysine. Bio/Technology, v.13, p.577-582 1995.

FRISCH, D.A.; GENGENBACH, B.G.; THOMMEY, A.M.; SELLENER, J.M.; SOMERS, D.A.; MYERS, D.E. Isolation and Characterization of Dihydrodipicolinate Synthase from maize. Plant Physiology, v.96, p.444-452, 1991.

GALILI, G. Regulation of Lysine and Threonine Synthesis. The Plant Cell, v.7, p.899906, 1995.

GALLUSCI, P.; VAROTT, S.; MATSUOKO, M.; MADDALONI, M.; THOMPSON, R.D. Regulation of cytosolic pyruvate, orthophosphate dikinase expression in developing maize endosperm. Plant Molecular Biology, v.31, p.45-55, 1996. 
GAZIOLA, S.A.; TEIXEIRA, C.M.G.; LUGLI, J.; SODEK, L.; AZEVEDO, R.A. The enzimology of lysine catabolism in rice seeds: Isolation, characterization and regulatory properties of lysine 2-oxoglutarate reductase/saccharopine dehydrogenase bifunctional polypeptide. European Journal of Biochemestry, v.247, p.364-371, 1997.

GAZIOLA, S.A.; SODEK, L.; ARRUDA, P.; LEA, P.J.; AZEVEDO, R.A. Degradation of lysine in rice seeds: Effect of calcium, ionic strength, $S$-adenosylmethionine and $S$-2-aminoethyl-L-cysteine on the lysine 2-oxoglutarate reductase-saccharopine dehydrogenase bifunctional enzyme. Physiologia Plantarum, v.110, p.164-171, 2000 .

GHISLAIN， M.; FRANKARD， V.; VANDENBOSSCHE，D.; MATHEWS，B.; JACOBS, M. Molecular analysis of the aspartate kinase-homoserine dehydrogenase gene from Arabidopsis thaliana. Plant Molecular Biology, v.24, p.835-851, 1994.

GONÇALVES-BUTRUILLE, M.; SZAJNER, P.; TORIGOI, E.; LEITE, A.; ARRUDA, P. Purification and characterization of the bifunctional enzyme lysine ketoglutarate reductase-saccharopine dehydrogenase from maize. Plant Physiology, v.110, p.765$771,1995$.

GRANT, M.; BEVAN, M.W. Asparaginase gene expression is regulated in a complex spatial and temporal pattern in nitrogensink tissues. Plant Journal, v.5, p.695-704, 1994.

GUPTA, S.C.; ASNANI, V.L.; KHARE, B.P. Effect of the opaque-2 gene in maize (Zea mays L.) on the extent of infestation by Sitophilus oryzae L. Journal of Stored Products Research, v.6, p.191-194, 1970. 
HABBEN, J.E.; KIRLEIS, A.W.; LARKINS, B.A. The origem of lysine-containing proteins in the opaque-2 maize endosperm. Plant Molecular Biology, v.23, p.825838, 1993.

HIBBERD, K.A.; WALTER, T.; GREEN, C.E.; GENGENBACH, B.G. Selection and characterization of a feedback insensitive tissue culture of maize. Planta, v.148, p.183-187, 1980.

HIBBERD, K.A.; GREEN, C.E. Inheritance and expression of lysine plus threonine resistance selected in maize tissue culture. Proceeding of National of the Academy of Science USA, v.79, p.559-563, 1982.

HINNEBUSCH, A.G. Mechanisms of gene regulation in the general control of amino acid biosynthesis in Saccharomyces cerevisiae. Microbiology Review, v.52, p.248$273,1988$.

KANEKO, T.; HASHIMOTO, T.; KUMPAISAL, R.; YAMADA, Y. Molecular cloning of wheat dihydropicolinate synthase. Journal of Biological Chemistry, v.265, p.17451-17455, 1990.

KARCHI, H.; SHAUL, O.; GALILLI, G. Seed specific expression of a bacterial desintetized aspartate kinase increases the production of seed threonine and methionine in transgenic tobaco. The Plant Journal, v.3, p.721-727, 1993.

KARCHI, H.; SHAUL, O.; GALILLI, G. Lysine sinthesis and catabolism are ccordinately regulated during tobacco seed development. Proceeding of National of the Academy of Science USA, v.91, p.2577-2581, 1994.

KARCHI, H.; MIRON, D.; BEN-YAACOV, S.; GALILI, G. The Lysine-Dependent Stimulation of Lysine Catabolism in Tobacco Seed Requires Calcium and Protein Phosphorylation. The Plant Cell, v.7, p.1963-1970, 1995. 
KEMPER, E.L.; CORD NETO, G.; CAPELLA, A.N.; GONÇALVES-BUTRUILLE, M.; AZEVEDO, R.A.; ARRUDA, P. Structure and regulation of the bifunctional enzyme lysine-oxoglutarate reductase-saccharopine dehydrogenase in maize. European Journal of Biochemistry, v.253, p.720-729, 1998.

KEMPER, E.L.; CORD NETO, G.; PAPES, F.; MARTINEZ MORAES, K.C.; LEITE, A.; ARRUDA, P. The role of opaque2 in the control of lysine-degrading activities in developing maize endosperm. The Plant Cell, v.11, p.1981-1993, 1999.

KLIMCZAK, L.J.; COLLINGE, M.A.; FARINI, D.; GIULIANO, G.; WALKER, J.C.; CASHMORE, A.R. Reconstitution of Arabidopsis casein kinase II from recombinant subunits and phosphorylation of transcription factor GBF-1. The Plant Cell, v.7, p.105-115, 1995.

KOCHHAR, S., KOCHHAR, V.K.; SANE, P.V. Isolation, characterization and regulation of isoenzynes of aspartate kinase differentialy sensitive to calmodulin from spinach leaves. Biochimca et Biophysica Acta, v.880, p.220-225, 1986.

KOCHHAR, S.; PATIL, T.N.; KOCHHAR, V.K; SANE, P.V. Detection of aspartate kinase in rat liver and its activation by $\mathrm{Ca}^{++}$and calmodulin. Biochemistry International, v.14, p.319-325, 1987.

KODRZYCKI, R.; BOSTON, R.S.; LARKINS, B.A. The opaque-2 mutation of maize differentially reduces zein gene transcription. Plant Cell, v.1, p.105-114, 1989.

KRISHNASWAMY, S.; BRYAN, J.K. Caracterization of ligand-induced states of maize homoserine dehydrogenase. Archives of Biochemistry and Biophysics, v. 227, p.210-224, 1983. 
KRISHNASWAMY, S.; BRYAN, J.K. Use of monoclonal antibodies for the purification and characterization of the threonine-sensitive isozyme of maize homoserine dehydrogenase. Archives of Biochemistry and Biophysics, v. 246, p.250-262, 1986.

KUMPAISAL, R.; HASHIMOTO, T.; YAMADA, Y. Purification and characterization of dihydrodipicolinato synthase from wheat suspension cultures. Plant Physiology, v.85, p.145-151, 1987.

KWON, T.; SASAHARA, T.; ABE, T. Lysine accumulation in transgenic tobacco expressing dihydrodipicolinate synthase of Escherichia coli. Journal of Plant Physiology, v.146, p.615-621, 1995.

LANDRY, J.; MOUREAUX. Hétérogénéité des glutélines du grain de mais: extration sélective et composition en acids aminés des trois fractions isolés. Bulletin de la Societe de Chimie Biologique, v.52, p.1021-1037, 1970.

LEA, P.J.; MILLS, W.R.; MIFLIN, B.J. The isolation of a lysine-sensitive aspartate kinase from pea leaves and its involvement in homoserine biosynthesis in isolated chloroplast. FEBBS Letters, v.98, p.165-168, 1979.

LEA, P.J.; WALLSGROVE, R.M.; MIFLIN, B.J. The biosynthesis of amino acids in plants. In: BARRET G.C.(Ed.) Chemistry and biochemistry of the amino acids. London: Chapman and Hall, 1985, p.197-226.

LENDING, C.R.; LARKINS, B.A. Effect of the floury-2 locus on protein body formation during maize endosperm development. Protoplasma, v.171, n.3-4, p.123133, 1992. 
LOESCH, P.J.; FOLEY, D.C.; COX, D.F. Comparative resistance of opaque-2 and normal inbred lines of maize to ear-rotting pathogens. Crop Science, v.16, p.841842, 1976.

LOHMER, S.; MADDALONI, M.; MOTTO, M.; DI FONZO, N.; HARTINGS, H.; SALAMINI, F.; THOMPSON, R.D. The maize regulatory locus Opaque-2 encodes a DNA-binding protein which activates the transcription of the b-32 gene. EMBO Journal, v.10, p.617-624, 1991.

LUGLI, J.; GAZIOLA, S.A.; AZEVEDO, R.A. Effects of calcium, Sadenosylmethionine, S-(2-aminoethyl)-L-cysteine, methionine, valine and salt concentration on rice aspartate kinase isoenzymes. Plant Science, v.150, p.51-58, 2000.

MA, Y.; NELSON, O. E. Amino acid composition and storage proteins in two new high-lysine mutants in maize. Cereal Chemistry, v.52, p.412-419, 1975.

MADDALONI, M.; DONINI, G.; BALCONI, C.; RIZZI, E.; GALLUSCI, P.; FORLANI, F.; LOHMER, S.; THOPMSON, R.; SALAMINI, F.; MOTTO, M. The transcriptional activator Opaque-2 controls the expression of a cytosolic form of a pyruvate orthophosphate dikinase-1 in maize endosperm. Molecular \& General Genetic, v.250, n.5, p.647-654, 1996.

MAROCCO, A.; SANTUCCI, A.; CERIOLI, S.; DI FONZO, N.; THOMPSON, R.; SALAMINI, F. 3 high- lysine mutations control the level of atp-binding hsp70-like proteins in the maize endosperm. The Plant Cell, v.3, n.5, p.507-515, 1991.

MATTHEWS, B.F.; SHYE, S.C.H.; WIDHOLM, J.M. Mechanism of resistence of a selected carrot cell suspension culture to S-(aminoethyl)-L-cysteine. Z Pflanzenphysiol, v.96, p.453-463, 1980. 
MATTHEWS, B.F.; WIDHOLM, J.M. Expression of aspartokinase, dihidropicolinato synthase and homoserine dehydrogenase during growth of carrot (Daucus carota cultivar Danvars) cell suspension culture on lysine-supplemented and threonine supplement media. Z Naturforsch Sect C.Biosci, v.34, p.1177-1185, 1979a.

MATTHEWS, B.F.; WIDHOLM, J.M. Enzyme Expression in Soybean Cotyledon, Callus, and Cell-Suspension Culture. Canadian Journal of Botany, v.57, n.4, p.299-304, 1979b.

MAURI, I.; MASSIMO, M.; LOHMER, S.; SALAMINI, E.; THOMPSON, R.; MARTEGANI, E. Functional expression of the transcriptional activator Opaque-2 of Zea mays in transformed yeast. Molecular \& General Genetic, v.241, p.319$326,1993$.

MERTZ, E.T.; BATES, L.S.; NELSON, O.E. Mutant gene that changes protein composition and increase lysine content of maize endosperm. Science, v.145, p.279$280,1964$.

MIRON, D.; BEN-YAACOV, S.; RECHES, D.; SCHUPPER, A.; GALILI, G. Purification and characterization of bifunctional lysine-ketoglutarate reductase/saccharopine dehydrogenase from developing soybean seeds. Plant Physiology, v.123, p.655-663, 2000.

MISRA, P.S.; MERTZ, E.T.; GLOVER, D.V. Characteristic of proteins in single and double endosperm mutants of maize. In: BAUMAN, L.F.; MERTZ, E.T.; CABAllO, A.; SPRAGUE, E.W. (Ed) High quality protein maize. Dowden: Hutchinson and Ross, 1975, p.291-305. 
MOTTO, M.; MADDALONI, M.; PONZIANI, G.; BREMBILLA, M.; MAROTTA, R.; DI FONZO, N.; SOAVE, C.; THOMPSON, R.; SALAMINI, F. Molecular cloning of the $o 2-m 5$ allele of Zea mays using transposon marking. Molecular \& General Genetic, v.212, p.488-494, 1988.

MUEHLBAUER, G.J.; SOMERS, D.A.; MATTHEWS, B.J.; GENGENBACH, B.G. Molecular genetics of the maize (zea mays 1) aspartate kinase-homoserine dehidrogenase gene family. Plant Phisyology, v.106, p.1303-1312, 1994.

MULLER, M.; MUTH, J.R.; GALLUSCI, P.; KNUDSEN, S.; MADDALONI, M.; MOTTO, M.; SCHMITZ, M.; SALAMINI, F.; VON WETTSTEIN, D.; THOMPSON, R.D. Regualtion of storage protein synthesis in cereal seeds: developmental and nutritional aspects. Journal of Plant Physiology, v.145, p.606$613,1995$.

NEGRUTIU, I.; CATTOIR-REYNEARTS, A.; VERBRUGGEN, I.; JACOBS, M. Lysine overproducer mutants with an altered dihydropicolinte synthase from protoplast culture of Nicotiana sylvestris. Theorical Applied and Genetics, v.68, p.11-20, 1984.

NIGAM, S.N.; MACCONNEL W.B. Studies on wheat plants using carbon-14 compounds. Canadian Jouranl of Biochemestry and Physiology, v.41, p.1367$1371,1963$.

OSBORNE, T.B.; MENDEL, L.B. Nutritive properties of proteins of the maize kernel. Journal of Biological Chemistry, v.18, p.1-6, 1914.

OTTOBONI, L.M.M.; STEFFERSON, D.M. Localization of zein genes in maize. Biochemical Genetics, v.25, p.123-142, 1987. 
PATTE, J.C.; LE-BRAS, G.; COHEN, G.N. Regulation by methionine of the synthesis of a third aspartate kinase and a second homoserine dehydrogenase in Escherichia coli K12. Biochimica et Biophysica Acta, v.136, p.245-257, 1967.

PERL, A.; SHAUL, O.; GALILI, G. Regulation of lysine synthesis in transgenic potato plants expressin a bacterial dihydrodipicolinate synthase in their chloroplasts. Plant Molecular Biology, v.19, p.815-823, 1992.

PLOTNIKOV, V. K.; BAKALDINA, N. B. Differential stability of zein mRNA in developing corn kernel. Plant Molecular Biology, v.31, p.507-515, 1996.

RAFALSKI, J.A.; FALCO, S.C. Structure of the yeast HOM3 gene which encodes aspartokinase. Journal of Biological Chemistry, v.263, p.2146-2151, 1988.

RELTON, J.M.; BONNER, P.RL.; WALlSGROVE, R.M.; LEA, P.J. Physical and kinetic properties of lysine-sensitive aspartate kinase purified from carrot cell suspension culture. Biochimica et Biophysica Acta, v.953, p.48-60, 1988.

ROGNES, S.E.; LEA, P.J.; MIFLIN, B.J. S-adenosilmetionine: A novel regulator of aspartate kinase. Nature, v.287, p.357-359, 1980.

SAINIS，J.K.; MAYNE，R.G.; WALLSGROVE，R.M.; LEA，P.J.; MIFLIN，B.J. Localisation and characterization of homoserine dehydrogenase isolated from baley and pea leaves. Planta, v.152, p.491-496, 1981.

SAINT-GIRONS, I.; MARGARITA, D. Fine estructure analysis of the threonine operon in Escherichia coli K12. Molecular \& General Genetic, v.162, p.101-108, 1978. 
SAKANO, K.; KOMAMINE, A. Change in the Proportion of Two Aspartokinases in Carrot Root Tissue in Response to in Vitro Culture. Plant Physiology, v.61, p.115$118,1978$.

SHAUL, O.; GALILLI, G. Increased lysine synthesis in transgenic tobacco plants expressing a bacterial dihydropicolinate synthase in their chloroplasts. The Plant Journal, v.2, p.203-209, 1992a.

SHAUL, O.; GALILLI, G. Threonine overproduction in transgenic tobacco plants expressing a mutant desensitized aspartate kinase of Escherichia coli. Plant Physiology, v.100, p.1157-1163, 1992b.

SHAW, J.F.; KU, C.-Y. Regulation and properties of rice (Oryza sativa cultivar Shingshu) aspartokinase. Botanical Bulletin of Academy Sinica, v.25, p.45-58, 1984.

SCHMIDT, R.J.; KETUDAT, M.; AUKERMAN, M. J.; HOSCHEK, G. Opaque-2 is a transcriptional activator that recognizes a specific target site in 22-kd zein genes. The Plant Cell, v.4, p.689-700, 1992.

SHERMA, J. Thin-layer chromatography in food and agricultural analysis. Journal of Chromatography, v.880, p.129-147, 2000.

SODEK, L. Bioshynthesis of lysine and other amino acids in the developing maize endosperm. Phytochemistry, v.15, p.1903-1906, 1976.

SODEK, L.; WILSON, C.M. Incorporation of leucine-C14 and Lysine-C14 into protein in the developing endosperm of normal and opaque-2 corn. Archives of Biochemistry and Biophysics, v.140, p.29-38, 1970. 
SODEK, L.; WILSON, C.M. Amino acid composition of proteins isolated from normal, opaque-2, and floury-2 corn endosperm by a modified osborne procedure. Journal of Agricultural and Food Chemistry, v.19, n.6, p.1144-1150, 1971.

STADTMAN, E.R.; COHEN, G.N.; LE-BRAS; ROBINSON-SZULMAJSTER, H. Feedback inhibition and repression of aspartokinase activity in Escherichia coli and Saccharomyces cerevisiae. Journal of Biological Chemistry, v.236, p.2033-2038, 1961.

TANG, G.; MIRON, D.; ZHU-SHIMONI, J.X.; GALILI, G. Regulation of lysine catabolism through lysine-ketoglutarate reductase and saccharopine dehydrogenase in Arabidopsis. The Plant Cell, v.9, p.1305-1316, 1997.

TEIXEIRA, C.M.G.; GAZIOLA, S.A.; LUGLI, J.; AZEVEDO, R.A. Isolation, partial purification and characterization of isoenzynes of aspartate kinase from rice seeds. Journal of Plant Physiology, v.153, p.281-289, 1998.

TZCHORI, I. B.-T.; PERL, A.; GALILI, G. Lysine and threonine metabolism are subject to complex petterns of regulation in Arabidopsis. Plant Molecular Biology, v.32, p.727-734, 1996.

VARAGONA, M.J.; SCHMIDT, R.J.; RAIKHEL, N.V. Monocot regulatory protein Opaque-2 is localized in the nucleus of maize endosperm and transformed tobacco plants. The Plant Cell, v.3, p.105-113, 1991.

VAUTERIM, M.; JACOBS, M. Isolation of a poplar and Arabidopsis thaliana dihidrodipicolinate synthase cDNA clone. Plant Molecular Biology, v.25, p.545$550,1994$. 
VAUTERIM, M.; FRANKARD, V.; JACOBS, M. The Arabidopsis thaliana dhdps gene encoding dihydrodipicolinato synthase, key enzyme of lysine biosynthesis, is expressed in a cell-specific manner. Plant Molecular Biology, v.39, p.695-708, 1999.

VICENTE-CARBAJOSA, J.; MOOSE, S.P.; PARSON, R.L.; SCHMIDT, R. J. A maize zinc-finger protein binds the prolamin box in zein gene promoters and interacts with the basic leucine ziper transcriptional activator Opaque2. Proceding of National of the Academy of Science USA, v.94, p.7685-7690, 1997.

WANG, X.; LARKINS, A Genetic analysis of amino acid accumulation in opaque-2 maize endosperm. Plant Physiology, v.125, p.1766-1777.

WEISEMANN, J.M.; MATTHEWS, B.F. Identification and expression of a cDNA from Daucus carota encoding a bifunctional aspartokinase-homoseine dehydrogenase. Plant Molecular Biology, v.22, p.301-312, 1993.

WILSON, B.J.; GRAY, A.A.; MATTHEWS, B.F. Bifunctional protein in carrot contains both aspartokinase and homoserine dehydrogenase activities. The Plant Physiology, v.97, p.1323-1328, 1991.

YAU, J.C.; BOCKHOLT, A.J.; SMITH, J.D.; ROONEY, L.W.; WANISKA, R.D. Maize endosperm proteins that contribute to endosperm lysine content. Cereal Chemistry, v.76, n.5, p.668-672, 1999.

YUNES, J.A.; CORD NETO, G.; SILVA, M.J.; LEITE, A.; OTTOBONI, L.M.M.; ARRUDA, P. The transcriptional activator Opaque2 recognizes two different target sequence in the $22 \mathrm{kDa}$ prolamin genes. The Plant Cell, v.6, p.237-249, 1994. 
YUNES, J.A.; VETTORE, A.L.; SILVA, M.J.; LEITE, A.; ARRUDA, P. Cooperative DNA binding and sequence discrimination by the Opaque2 bZIP factor. The Plant Cell, v.10, p.1941-1955, 1998.

ZHANG, S.Q.; JIN, C.D.; ROUX, S.J. Casein kinase II-type protein-kinase from pea cytoplasm and its inactivation by alkaline-phosphatase in-vitro. Plant Physiology, v.103, n.3, p.955-962, 1993.

ZHU-SHIMONI, J.X.; LEV YADUM, S.; MATTHEWS, B.; GALILLI, G. Expression of an aspartate kinase homoserine dehydrogenase gene is subject to specific spatial and temporal regulation in vegetative tissue, flowers, and developing seeds. Plant Physiology, v.113, p.695-706, 1997. 
APÊNDICE: Reagentes 


\section{$\underline{\text { Reagentes: }}$}

Tampão A:

- $50 \mathrm{mM}$ Acetato de sodio.

- $50 \mathrm{mM}$ de $\mathrm{Na}_{2} \mathrm{HPO}_{4}$.

- $\quad 1.5 \mathrm{ml}$ ácido acético concentrado. -> pH 7.25.

- Completar para $960 \mathrm{ml}$ com $\mathrm{H}_{2} \mathrm{O}$ Milli-Q.

- $20 \mathrm{ml}$ de tetrahydrafuran.

- $20 \mathrm{ml}$ de metanol.

- Filtrar e desgaseificar com ultrasom + vácuo.

\section{Tampão B:}

- $650 \mathrm{ml}$ de $\mathrm{MeOH}$.

- $350 \mathrm{ml}$ de $\mathrm{H}_{2} \mathrm{O}$ Milli- $Q$.

- Desgaseificar com ultrasom + vácuo.

Reagente OPA:

\section{Borato, $\mathrm{pH} 9.5$}

- 2.4 g de ácido bórico em 90 ml H20.

- Ajustar o pH para 9.5, com $\mathrm{NaOH}_{2} \mathrm{~N}$.

- Completar para $100 \mathrm{ml}$.

- OPA-borato, $\mathrm{pH} 9.5$

- $50 \mathrm{mg}$ em $1 \mathrm{ml} \mathrm{MeOH}$.

- $6.5 \mathrm{ml}$ de borato, $\mathrm{pH}$ 9.5, filtrar em Millipore $0.22 \mu \mathrm{m}$. 


\section{Reagente OPA}

- $2.5 \mathrm{ml}$ de OPA-borato, $\mathrm{pH} 9.5$.

- $20 \mu \mathrm{l}$ de 2-mercaptoetanol (usar no dia e/ou guardar na geladeira e após 1 semana adicionar mais $2 \mathrm{ME})$.

Cromatograma com aminoácidos padrões:

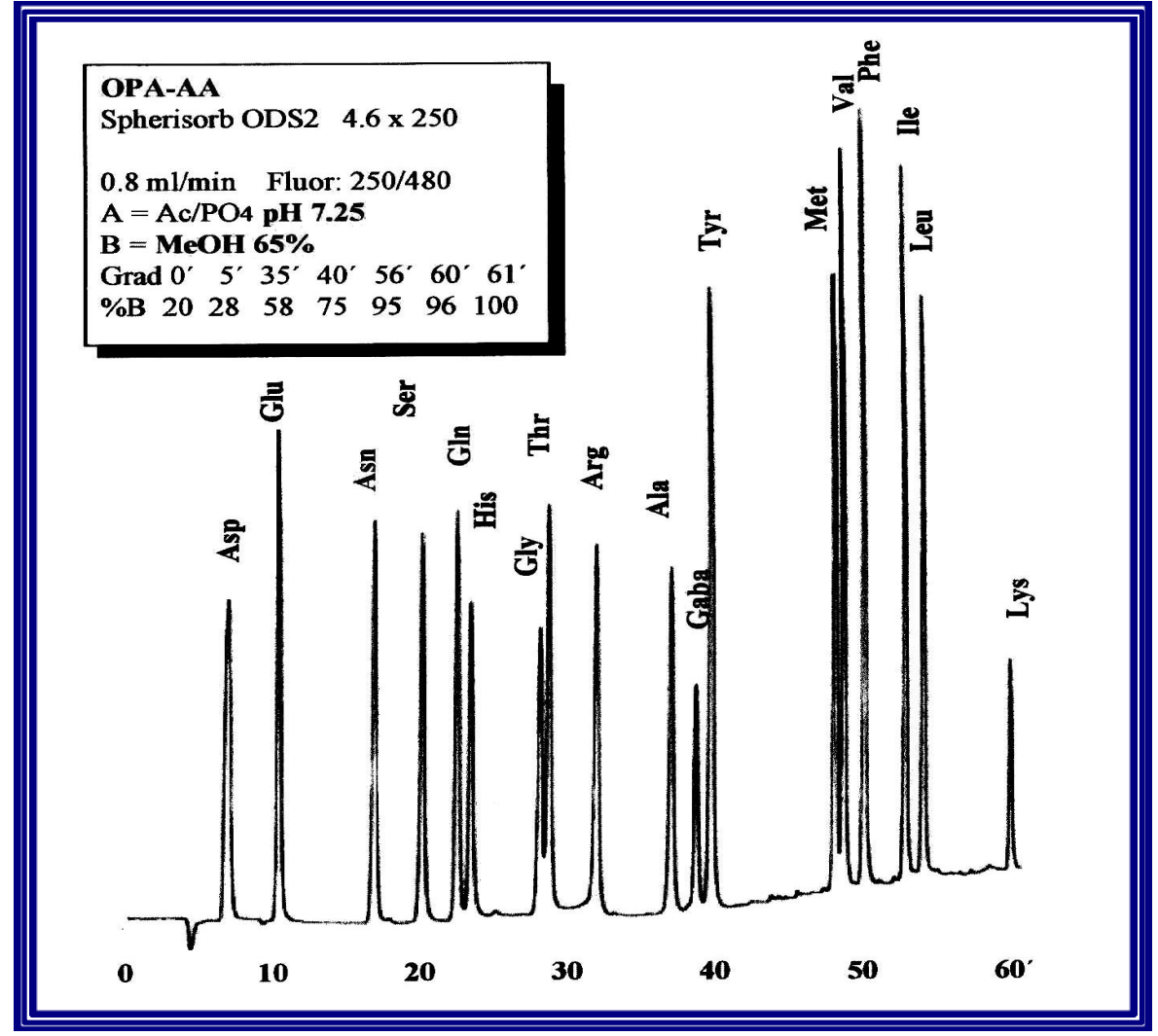




\section{Aminoácidos indentificados}

Asp: asparagina.

Glu: glutamato.

Asn: aspartato.

Ser: serina.

Gln: glutamina.

His: histidina.

Gly: glicina.

Thr: treonina.

Arg: arginina.

Ala: alanina.

Gaba: ácido giberélico.

Tyr: tirosina.

Met: metionina.

Val: valina.

Phe: fenilalanina.

Ile: isoleucina.

Leu: leucina.

Lys: lisina. 